


\section{HARVARD UNIVERSITY}

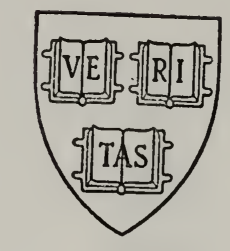

\section{LIBRARY}

OF THE

Museum of Comparative Zoology

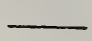






\section{THE INTERNATIONAL \\ CONVENTION \\ FOR \\ THE PROTECTION OF BIRDS}

CONCLUDED IN 1902;

AND

HUNGARY.

HISTORICAL SKETCH.

WRITTEN BY ORDER OF HIS EXC.

IGNATIUS DE DARÁNYI,

MUS. COMP. ZOOL. UBRARY

HUNGARIAN MINISTER OF AGRICULTURE

\section{BY \\ OTTO HERMAN \\ LATE M. P.}

DIRECTOR OF THE HUNG. CENTR. BUR. F. ORNITHOLOGY.

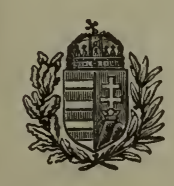

\section{BUDAPEST}

VICTOR HORNYÁNSZKY, COURT PRINTER 
Boston Society of Natural History.

F ROM

Miss fessie C. Findoul

Received $\operatorname{sic} \dot{\alpha} 23,1000$ 
The Royal Fungarian Minister of Bgriculture

mr. Jgnatius de Darányi,

begs to accept this presentation $=$ copy of the Fistory of the International Convention forthe protection of Birds, with the reguest of kind attention. 

The Royal Hungarian Minister of Agriculture had caused in 1900 the large work of Stephen Chernel de Chernelháza on "Ornithologia Oeconomica" of Hungary, to be translated into French, in order to make accessible to the knowledge of the civilized nations the studies of Hungary in the domain of agricultural ornithology. As the publications of the Hungarian State Office for Ornithology under the direction of Mr. Otto Herman appear also in German, the Minister now decided to publish the History of the Convention for the protection of Birds in English. This publication endeavours to give a description of the present state of international protection of birds useful to agriculture and will, it is hoped, serve the cause of progress. 

THE INTERNATIONAL

CONVENTION

FOR

THE PROTECTION OF BIRDS

CONCLUDED IN 1902;

AND

HUNGARY.

HISTORICAL SKETCH.

WRITTEN BY ORDER OF HIS EXC.

IGNATIUSS DE DARÁNYI, HUNGARIAN MINISTER OF AGRICULTURE

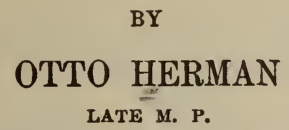

LATE M. P.

DIRECTOR OF THE HUNG. CENTR. BUR. F. ORNITHOLOGY.

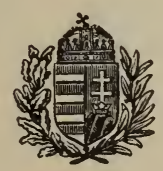

BUDAPEST

VICTOR HORNYÁNSZKY, COURT PRINTER 1907 


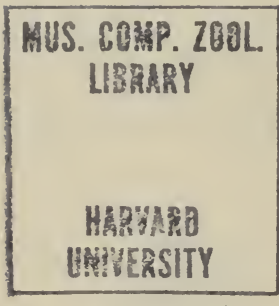

Gift - Boston Excel of Natural History.

$98^{8^{5}} 9$ 


\section{CONTENTS.}

Page

Foreword . . . . . . . . . . . . . . . 1

I. Generalia . . . . . . . . . . . . . . . . . 8

Introduction . . . . . . . . . . . . . . . . . . . . 9

Birds and Nature . . . . . . . . . . . . . . . . . . 9

Birds and Man . . . . . . . . . . . . . . . . . 20

II. Historical Part . . . . . . . . . . . . . . . . . 26

Preliminaries . . . . . . . . . . . . . . 27

The meeting of German agriculturists and foresters, 1868 . . 32

The first steps . . . . . . . . . . . . . . . . . 33

The points of Frauenfeld and Targioni Tozetti . . . . . . 35

International agricultural Congress, Vienna, 1873 . . . . . 38

Tschudi's proposal . . . . . . . . . . . . . . . . 40

Marenzeller's proposal . . . . . . . . . . . . . . 41

Brehm's proposal . . . . . . . . . . . . . . . . 46

Settegast's proposal. . . . . . . . . . . . . . . . 48

The Vienna Resolution . . . . . . . . . . . . 50

The „Declaration" of 1875 . . . . . . . . . . . . . 52

Developments . . . . . . . . . . . . . . . 56

The First International Ornithological Congress, 1884 . . . 59

Altum's proposal . . . . . . . . . . . . . . . 61

Palacky's proposal . . . . . . . . . . . . . . 64

Russ's proposal . . . . . . . . . . . . . . . . 64

Fatio's proposal . . . . . . . . . . . . . . . . 64

Borggreve's proposal . . . . . . . . . . . . . 64

Kermenič's proposal . . . . . . . . . . . . . 65 
Instructions . . . . . . . . . . . . . . . . . . . 66

The resolution of the Congress . . . . . . . . . . . 66

The International Protection of Birds in Hungary . . . . . 69

The Second International Ornithological Congress, 1891 . . 73

Liebe-Wangelin's Report . . . . . . . . . . . . 77

Izidor Máday's Report. . . . . . . . . . . . . . . 83

The position of the cause in 1891 . . . . . . . . . . 87

Baron Berlepsch on the extermination of birds in Italy . . . 90

The immediate preliminaries of the International Convention. 93

The invitation of the French Government, 1893 . . . . . 94

The representation of Hungary, 1895 . . . . . . . . . . . 96

Preliminary Conference at Vienna . . . . . . . . . . 96

Ditto, at Berlin . . . . . . . . . . . . . . . . 97

The International Conference at Paris . . . . . . . . 100

Members of the Conference. . . . . . . . . . . 100

The French Schedules . . . . . . . . . . . . . . 104

Italian statement . . . . . . . . . . . . . . . . . 110

Agreement . . . . . . . . . . . . . . . . . 112

The draft of the Convention as agreed upon . . . . . 113

The Association of French "Chasseurs" . . . . . . . . 114

The further progress of the Convention . . . . . . . 117

Switzerland's demand . . . . . . . . . . . . . . . 119

Sweden's demand . . . . . . . . . . . . . . 120

The Third International Ornithological Congress, 1900 . . . 121

The International Agricultural Congress, 1900 . . . . . . 121

The milliners and feather-factors of Paris. . . . . . . . 122

The Ornithologists' Resolution . . . . . . . . . . . '. 122

The Convention in Hungary. . . . . . . . . . . . . 123

The Convention in Parliament. . . . . . . . . . . . 123

The sanctioning of same . . . . . . . . . . . . 125

The text of the Convention . . . . . . . . . . 126

Concluding words . . . . . . . . . . . . . 138

III. The Protection of Birds in Hungary. . . . . . . . . . 145

Economic Ornithology . . . . . . . . . . . . . . 152

Circular decree . . . . . . . . . . . . 155

Mammalia . . . . . . . . . . . . . 155

Birds . . . . . . . . . . . . . 155 
Comparisons

163

German Imperial Law . . . . . . . . . . . . . . . 164

Schedule of German Federal States . . . . . . . . . . 165

British Acts and Schedule . . . . . . . . . . . . 169

The Future . . . . . . . . . . . . . . . . . . . 174

Extinction of birds . . . . . . . . . . . . . . . . 175

Berlepsch's system . . . . . . . . . . . . . . . 175

Practical protection . . . . . . . . . . . . . . 175

„Birds' Day“ . . . . . . . . . . . . . . . . . . 175

Historical synopsis . . . . . . . . . . . . . . . . 179

Index of names . . . . . . . . . . . . . . . . . 185

Bird-Dictionary . . . . . . . . . . . . . . . . . 199

Documents . . . . . . . . . . . . . . . . . 219

Index of subjects . . . . . . . . . . . . . . . . . 233

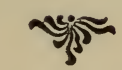





\section{EXPLANATION OF ABBREVIATIONS.}

For. Min. = Austro-Hungarian Foreign Ministry.

Hung. Pres. = Hungarian Prime Ministry.

Hung. Min. Agr. = Hungarian Ministry of Agriculture.

Hung. Min. Jus. = Hungarian Ministry of Justice.

Aust. Min. Agr. = Austrian Ministry of Agriculture.

M. P. I. = Hungarian Ministry of Public Instruction.

$\delta^{\pi}=$ Male.

$q=$ Female.

* = The birds which are asterisked, are in the shedule of the Convention.

The other signs are explained at the head of the respective section or chapter. 
who have kept aloof we find Italy, a State of most extraordinary importance.

The constant decrease of birds useful to agriculture, and the corresponding increase in the number of destructive insects, called attention to the necessity for an international convention for the protection of the former as far back as 1868 , a date contemporaneous with the revival of constitutionalism in Hungary; and, as a result of the progress of events, the constitutional Hungarian governments were among the first to take the initiative, using their infiuence more than once to provoke a decisive issue.

This fact in itself is sufficient to justify the determination of the constitutional Hungarian Minister for Agriculture to publish the story of the development of the cause, in the form of an historical sketch; choosing the form of a sketch for the simple reason that the documents treating of the negotiations which have lasted for more than a generation, and are often of a confidential nature, are as yet inaccessible. This fact must serve as an apology for any deficiencies of the present work, deficiencies that it is left to the historians of a later age to supply.

The publication of this sketch was, however, imperative in order to colleet the moments and results of the long protracted and often interrupted negotiations and present them from a uniform point of view: at the same time it displays the deficiencies, thus rendering a service to the cause by pointing 
out what still requires to be done internationally before a perfectly satisfactory state of things can be attained.

Before passing on, the fact must be particularly emphasised that the Hungarian Ministry of Agriculture has, from the start, been in favour of international protection of birds useful to agriculture, a position which the said Ministry has consistently maintained.

Another motive for the publication of this sketch is found in the fact that the International Convention in question is in organic connexion with our own protective measures, which are of importance, nay, more, a vital necessity, for the simple reason that our national resources are chiefly dependent even today on our agriculture and its branches.

Our special measures taken to protect useful birds reached their climax at the period when the International Convention was made law. And as, by virtue of $\S 11$ of the said Convention, the States that sign the same are bound to inform each other of any special measures they may take, such information being conveyed to the respective quarters by the French Government, the inclusion in this sketch of the measures taken by our authorities is both useful and necessary.

As far as the consummation of the work is concerned, we must mention 1) the decree issued on June 19. 1906 (No. 3686) by His Excellency Mr. 
Ignácz Darányl, the Royal Hung. Minister of Agriculture, which orders State forests to be gradually provided with nesting-boxes, the only method for preserving at least a part of the birds useful to agriculture: and 2) a decree issued on April 27, 1906 (No. 26,120) by His Excellency Count AlBerT Apponyı, Royal Hung. Minister of Public Instruction, which orders the introduction of "Birds Days“ and ,Tree Days“ in the scheme of work of elementary schools.

These two decrees certainly form a consummation.

The principle of "suum cuique" incumbent on all historians requires us to make mention of the late Count Gyula AndRÁssy, formerly Prime Minister of Hungary, then Austrian and Hungarian Minister for Foreign Affairs, who in his latter capacity with much ingenuity brought about the Hungaro-AustroItalian „Declaration“, (1875) which did great service to the cause of international protection for birds by giving the negotiations a positive direction.

Before closing my prefatory remarks, I must express my heart-felt gratitude to His Excellency Mr. IGNÁCZ DARÁNYI for the flattering confidence he has reposed in me; of the officials of the imperial and royal Austrian and Hungarian Foreign Office to His Excellency Mr. Ladislaus MÜlleR (Chief of Department), to Messrs. Br. DÉnEs TALLiáN and Emil Brunner de Wattenwyl (Sectional Councillors); of the officials of the Royal Hung. 
Ministry of Agriculture particularly to Mr. LORÁND RÓTH de Pongyelok (Sectional Councillor), Mr. LajOS SzOmjas (Sectional Councillor) and Mr. LORÁND GYőRY (Ministerial Secretary); finally to Mr. E. H. DRESSER, the eminent British ornithologist, to the staff of the Tring Zoological Museum and to Mr. TSCHUSI DE SCHMIDTHOFFEN, the eminent Austrian ornithologist, for all the kind assistance they have respectively afforded me.

Lillafüred, Sept. 1906.

OtTo HeRman. 

GENERALIA.

GENERALIA.

(n) 



\section{Introduction.}

\section{Birds and Nature.}

The necessity for the organisation of an international settlement of the affairs of the bird-world was dictated by extremely natural causes closely bound up with the organic structure and mode of life of birds and, from a purely human point of view, with the conceptions of utility and noxiousness.

The fact that a whole generation was required to complete the convention agreed upon by a few European States, proves that the experts of the various States, often the governments too, took entirely different views of the bird, judging it from the point of view of their several conditions, which latter, in some States, threw insuperable difficulties in the way of an effectual arrangement. The end of all this was that, the respective State or States being unable to subscribe to the International Convention, the latter was signed and accepted as binding by only a few of the States of Europe.

Strictly speaking, then, the Convention, in its effects, has not yet been perfectly successful, for among those who have kept aloof from the movement are States of large dimensions and in other respects of no small importance: e. g. Russia in the North, Italy in the South and Great Britain in the West; though the latter, standing apart in this as in other matters, is taking its own special measures. 
These circumstances render it imperative that we should, before all, define birds and their significance in respect to nature and human society; for herein lies the true vocation and importance of the International Convention; hereby only can we form a proper conception of the same; and hereon depends the possibility of furthering an adequate development of the cause.

It is not a question of treating birds from a systematic point of view, i. e. from the point of view of descriptive natural history, in the common acceptation of the word; we must collect and employ all the biological observations (as well as the conclusions to be drawn therefrom) which science has amassed side by side with systematic formulae, and which, from the point of view of both nature and society, justify protection or the opposite. In a word we must treat of the importance or significance of birds in the household both of Nature and of Man.

The characterisation of birds from this point of view may be briefly summed up as follows.

Without taking into consideration those genera of birds -- such as the Ostrich family, the Kivi (Apteryx) etc. - which, though still extant, are the representatives of decadence, their peculiar characteristic being that they are not flyers and are consequently limited as to the power of changing their abode, which is, in general, considered, to be an essential feature of a "bird", - we intend to deal with those birds the organic structure of which includes, besides the power of flight, i. e. ability to change their abode, a tool-like, if we may call it so, and very multiform system of external organs. These properties, taken collectively, produce the extensive and intensive influence which may be summed up as the search of birds for their food.

The means of changing the haunts is the wing, which is 
multiform, this multiformity accounting for the variety in the manner of flight. This latter in some cases means merely a change of abode, e. $\mathrm{g}$. in those of partridges and quails; in others it is an essential preliminary to the acquisition of food, e. g. in that of the swallow, which seizes its flying prey, the insects, while in full flight. There are a whole series of modifications between these two extremes of wingstructure; we find birds which move only in a limited area, their sphere of influence being equally limited; and we find others, which migrate, according to the season, from one zone to the other, thus exercising an influence successively and in regular order on districts far apart from one another, with far different climates, and bringing about the transmission of bird-labour adapted to the succession of natural phenomena.

The variety of flight due to the various wing-structures creates a system of movement which enables birds to keep in touch, as it were, with those phenomena of nature which are indispensable to their subsistence and this system implies the work and the effect of the same.

The structure and effect of the wing, in its relation to birds, finds a parallel in that of the beak, this organ of birds so wonderful in its variety. If we look at the long lists of birds, we are met with a variety of beaks that seem to resemble a collection of tools; even if we merely consider the phenomena of our own climate, or the palaearctic zone.

Let us take as extremes the tiny beak of the little longtailed titmouse, which is smaller than a grain of rice, and that of the spoonbill, which is large and spoonshaped: between these two extremes we have the greatest variety of forms and modifications, which may be characterised as follows: the bill of the chiff-chaff is almost as fine as a needle and is suitable for seizing the smallest and most 
delicate insects; on the other hand the bill of the haw-finch is so powerful that it breaks the hardest cherrystone with the greatest ease; the tip of the woodcock's bill is a borer, which forms in reality an apparatus of touch, and when the bird bores into the ground the apparatus like a man's finger, enables it to trace the food buried in the ground; whereas the beaks of birds of prey are constructed for tearing flesh or dividing and are consequently, hooked and hatchet-like. And the beak, just as the wing, creates a system of work corresponding to the phenomena of nature a system which, while providing against the extinction of the species, by its influence helps to form extant conditions or, in other words, takes its share of the great economy of Nature.

And so it is with the feet of birds too. These too, by their own organic differences, form a manifold collection of tools, which, beginning from the foot of the threetoed ringed plover, present the greatest variety of modifications. In this varied collection we find the kingfisher's foot, suitable only for perching; that of the woodpecker which is yoke-toed (zygodactylic), presenting two toes to the front and two to the rear, a formation that enables the woodpecker to climb perpendicular or inclined trees; that of the nuthatch which enables the bird to climb up perpendicular or inclined trees and the branches of the same, even in an inverted position; that of the swift, the most perfect example of the "crab foot", which is only suitable for enabling the bird to remain in perfect security upon perpendicular surfaces, the claws being as sharp as needles; final those of birds of prey, the claws of which are, generaily speaking, murderous instruments, the sole suitable for throttling, while one of the toes (e. g. in the case of the owl) may be moved backwards or forwards as required. 
Consequently the foot, just as the beak or wing, creates a system of work corresponding to the phenomena of nature, which, while essential to the subsistence of each several bird, enables its owner to contribute its due share to the work of Nature's household.

That part of the internal organism of birds which belongs to this introduction, viz. the digestive organs or, in other words, the stomach, is also not uniform. On the one hand we have the tubelike stomach which in its simplicity is really only an enlargement of the alimentary canal or oesophagus, on the other the muscular stomach which by stones and gravel swallowed for the purpose actually grinds hard food that has been slightly softened in the craw.

This multiform and varied collection of organic structures is in itself enough to point out the variety of foods: and as the quantity of each several food is not the same, naturally the number of birds living on the respective foods is diverse. Consequently a bird may be rare, common or found in large quantities. In other words the number of individual birds representing each species is proportionate to the quantity of that particular food on which the species is dependent for its subsistence; and decreases or increases in proportion as the supply of food is deficient or copious.

The latter fact presents us with two sequences: firstly, Nature herself, if intact, does not recognise either useful or noxious birds, but regulates the number of individual birds in accordance with the order and conditions of their life, this regulation being, to use a modern term, automatic: on the other hand, where the ordinary conditions of Nature change, the proportion of bird species changes in accordance with variations in the supply of nourishment.

These facts account for the continual rarety of some species and the abundance of others; for the periodical appearance of 
some species, their disappearance and reappearance in other regions; they explain the existence of birds which merely migrate from hill to valley and vice-versa, as well as of those which remain in one place for years, changing their diet according to the season, enduring all hardships and not departing even in times of want; and, finally, they render intelligible the stupendous system of "migration“, a phenomenon closely bound up with the change of the seasons, the essential point of which is that many birds peculiar to northern regions leave home in winter for the South and wander to our temperate zone, whereas many of our feathered friends desert us when the cold weather approaches and retire to far distant southern climes. When spring comes, our own breeds return, while those who hibernated with us leave for their northern homes.

If we survey all these points, we may get a true if somewhat hazy picture of the significance of birds as represented in the work which neither Nature nor Man can dispense with with impunity, the loss of which cannot be supplied by any manner of artificial procedure.

It is particularly the life of insects and herbs that the labour of birds is called upon to regulate. The proportions of this labour are well illustrated, in the North, by the millions of gulls that live on animal food; in our climate, on the other hand, in places where human hands have but slightly or not at all disturbed the primeval state of Nature, by the cloud-like hosts of starlings and crows which are joined by thousands upon thousands of smaller gregarious seed-eating birds that prevent the over-growth of weeds.

Keen-eyed observers will discover that, to do certain forms of labour that only birds can accomplish, birds of widely diverse structure fly together or rather form organised, symbiotic labourer-bands. In our climate the most remarkable 
combined flock is that composed of several species of titmouse, nuthatches, small woodpeckers and tree-creepers, which, keeping together, systematically clean every part of the trees, dividing the labour in accordance with the peculiar structure of each several bird.

Hitherto we have treated birds only in their relation to intact Nature.

This relation changes, the moment man, in his own interests, interferes with Nature's work or, as we are wont to say, makes Nature his slave, at the same time producing essential changes in her progress.

By breaking up the virgin earth to sow it with cereals or plant herbs therein; by rooting out woods to use their trees or cultivate the territory they cover; by the regulation or draining off of waters, thus making essential changes in the relation of land to water - by all these and in similar ways man changes the condition of life of plants and animals.

By rotatory cultivation, carried out on a large scale, man multiplies lower-grade animals, particularly insects, that are dependent on the products of the earth, supplying them with favourable conditions of subsistence, the natural result of which is increase in numbers. And it is this which, from a human point of view, involves damage, against which man is bound to defend himself as best he can.

The surest and simplest means of defence for man to adopt would be to restore the natural state; as, however, in the interest of his own subsistence, he is unable to do that, he is obliged to defend himself by measures that will ward off or at least diminish the damage. And that means that he must artificially replace those conditions which, by disturbing the natural state, he has done away with or essentially altered. 
If we apply this to birds alone, we can formulate the following thesis: man must protect those birds which are of value to his own interests and put a check on those which are inimical to the same. By protection we mean of course that he must allow useful birds every chance of subsistence $i$. e. means of living and opportunities of increase.

If we turn our attention now to the differences in the conditions of life of animals and vegetation due to the geographical position of the particular region and to climatic divergencies, we shall find beyond doubt that the life of birds and the effects produced by the same cannot be treated from one and the same point of view.

The birds, - if we include the phenomenon of the grand migration and consider the northern part of the Eastern Hemisphere i. e. that part which falls between the Equator and the North Pole, - occupy the territory just defined; not to speak of those birds which entend their migrations beyond the Equator, i. e. to the South Pole.

Broadly speaking, the higher we penetrate into the polar regions, the fewer species of birds we meet; all the larger, however, the quantities of each species, a fact which corresponds with the simplicity and mightiness of the phenomena of polar Nature: the nearer we approach to the Equator, the more species of birds we find; but the appearance, of any particular species in masses becomes rarer, a fact which, in its turn, corresponds to the complexity of natural phenomena, among others to the vast variety (multifariousness) of lowergrade animals and of the whole vegetable world.

Any territory lying between the Pole and the Equator contains modifications corresponding to its situation; and the conception of the significance of birds varies with these modifications, for there are birds which in certain territorial conditions are useful, in others again are noxious. To take a 
concrete instance: the starling is undoubtedly useful in territories where animals are being bred on large pastures, for it clears the pasture and rids the animals of their parasites, but it is equally noxious in districts where there is intense cultivation, or where the greatest importance is attached to the production of bacciferous fruit. This fact proves again, that the feeding of birds may change with the season and surroundings or with opportunities: e. g. certain breeds of gulls, which by their mode of life are bound to water, appear on dry land when locusts or grasshoppers are plentiful, and hunt for them as long as the supply lasts.

Here mention must be made of a deficiency still extant in our knowledge of birds, i. e. that even today we have practically no detailed knowledge concerning the food of birds.

Inquiries in this direction were begun in the first year of the XX century, but have been carried on only sporadically. ${ }^{1}$

The fact that the relation of birds to territory is so very diverse has always rendered and still renders extremely difficult any international agreement as to the classification of birds to be protected and those to be extirpated, i. e. useful and noxious birds, treated by species; in fact it has often made such an agreement impossible seeing that our knowledge on certain points, e. g. concerning the question of food, is very deficient. In this field there is much that is uncertain, suppositional or traditional, a fact which renders the formation

1 At the Fourth International Ornithological Congress held in London in 1905, Hungary was the only country that could produce any results in this field. Inquiries are being made in Germany and Belgium. The task is a very difficult one, but the solving of the problem is important, as it will throw extraordinary light on the significance of birds. 
of an opinion by experts very difficult and accounts for the aversion or disdain that so often prevents a true conception of birds.

All that is certain is that many species of birds that are of significance in the economy of Nature and of Man, are scarcely remarkable, because they are small and live an obscure life; yet there are crowds of them dispersed in the temperate zone of the E. Hemisphere, which sometimes, in consequence of certain meteorological phenomena, flock together and may afford a conception of the mightiness of the work they represent and imply.

HeNRY GaETKE, the celebrated German ornithologist, ${ }^{1}$ who for fifty years made observations of all birds that appeared in Helgoland or passed over that island, writes of the golden-crested wren, that is small and of even more delicate structure than the wren, that one autumn it appeared in enormous flocks: - of the flock itself the celebrated observer writes that for days and nights these crowds of tiny birds passed over the island in thick masses like the flakes in a heavy snowstorm; those in need of rest literally covered the cliffs on the shore: there must have been millions. Under ordinary circumstances this little bird is a stay-at-home: and, though not at all common, it was still able to collect a flock of those dimensions. If we consider that this little bird, as far as we at present know, is exclusively an insect-eater doing its work with great diligence, we may form some conception of the dimensions and importance of the labour it performs.

Before completing these introductory remarks mention must be made of the means of propagation of birds - con-

1 "Der Vogelwart von Helgoland“; „Die Vogelwarte Helgoland" : these have appeared in English too. 
fining ourselves to those living on the territory here considered. There are very few birds that lay more than once a season. And there are but few species, if we confine ourselves to those under special consideration here, the nests of which are comparatively populous: some titmice have $12-18$, the quail from 10 to 16 , the partridge $14-18$; while the most important insect-eaters have from 5-6 eggs.

Over against the propagation we have the elements of extirpation, which are of three kinds. The first is part of the economy of Nature and is represented by the natural enemies of the birds, viz. small mammals of prey, birds of prey among the latter nest-robbers. The second is the catastrophe which generally overcomes those birds of passage that are obliged to cross the sea to reach their winter or breeding quarters. The causes of the catastrophe are meteorological, - famine resulting from icy-cold winters, storms, thick fogs of long duration, which overtake the winged travellers en route.

The above must be considered as restrictions imposed by Nature: and, though the first element may be combated by man's keeping down the number of the birds' natural enemies, there is nothing to be done against the second, for frost, storms and fogs are „forces majeures". Yet we can relieve the famines of winter. The comparatively insignificant increase and the natural restrictions in the case of birds must be set over against what birds act as restricting agents on, - the insect world, the propagation of which is generally a geometrical progression, and the world of vegetation with its often peculiar development and its mass of seeds which help to secure the existence and increase of some particular species. 


\section{Birds and Man.}

The third element of destruction is supplied by man, the most conscious and at the same time the most pitiless of beings.

The routes of the birds of passage from the Southern regions of Europe right up to Moscow are inhabited by Latin, Southern Slavs, Levantine, Turkish, Greek and South Russian races, all of whom are ornithophages i. e. bird-eaters, whose devices and tools for catching birds are naturally varied and of advanced structure. There are, particularly, some nets of gigantic proportions well fitted to the destruction of birds in masses.

We know that in some places the destruction of birds is on the decrease, that Spain is trying to mitigate the evil by influencing the youth for good, and has signed the International Convention just as France and Greece have done: but the real improvement, if it is to come at all, is reserved for the future. The perfection of the means of communication has made the transport of live prey easy, a fact that has enabled the masses of birds caught to be carried far away to the capitals of Central Europe, thus creating an extremely profitable branch of commerce. Consequently bird-catching has passed beyond the Mediterranean; and, on the northern shores of Africa it is not savages or semisavages, but Europeans settled there who plant their nets to catch the bird of passage, transporting the masses of wretched prisoners to the continent of Europe, there to serve as delicacies on the tables of those whose one ambition is to satisfy the cravings of the inner man.

Even the erections raised by man for his own and his fellows' protection claim hecatombs of birds of passage, we mean, of course, the lighthouses which, while guiding 
ships in their course, by their light attract the birds passing at night, that batter in their heads by thousands against the glass surrounding the lamps.

What masses of birds are here concerned is proved by the figures that appeared in the publications and were mentioned in the discussions of the section organised ${ }^{1}$ for the protection of birds and the study of economic ornithology at the Second International Ornithological Congress held at Budapest in 1891. The numbers are as follows: According to Prof. VAllon, in October 1890, 8829 quintals of small birds ( $=423,800$ birds) passed the customs frontier at Brescia. Among these at first were found, spotted flycatchers, pied flycatchers, whitethroats, garden warblers, lesser whitethroats, rock pipits, great titmice and blue titmice - all birds of the greatest value. According to another source, from Udine, during the migratory season, 200,000 small birds were despatched by rail: that makes altogether a total of some 620,000 birds, all, according to the lists, birds of the utmost value to agriculture. Near Montegrado, within 3 days, 14,000 swallows fell victims, and our eminent traveller, Count Charles Forgách, mentions that on the stonefield Crao no less than three million swallows fell into the nets of the bird-catchers. The export of quails from Egypt was as follows; in $1887,550,000$, in 1888 it rose to $1.235,000$, while in 1889 it was 900,000 , i. e. in three years a total of 2.685,000: the best markets for their consumption are London and Paris. We have official statements from Paris that speak of 114,000 larks. Count SALVADORI, the celebrated Italian ornithologist, has pointed out, with exact figures and state-

1 Dr. Th. Liebe und v. Wangelin. Referat über den Vogelschutz. Separatum. 1891. IzIDOR MÁDAY: Über den internat. Schutz der für die Bodencultur nützl. Vögel. Separatum. 1891. 
ment of species, that a single birdcatching apparatus (roccolo) has in 20 years cost 135,485 small birds their lives. These numbers are controllable; those which evade control, are still greater. These remarks and statistics apply only to birds meant for consumption and leave out of account altogether those hecatombs which the world of fashion demands. To this category belong the 400,000 pairs of lark-wings supplied by Finland to one single fashionable shop in Paris.

These are the details which we thought fit to write by way of introduction, for the better displaying the importance of the bird-question. The fact that, in the course of the discussion, no mention has been made of the humanitarian point of view is a consequence of the nature of the case; for where great material interests of mankind are involved and our point may be proved, to the exclusion of sentimentality, by the force of circumstances, the latter must be employed.

So we must place the interests of universal agriculture, on which man's subsistence depends, face to face with the misinterpretations of birds and their work from the point of view of material interest and with that really senseless extermination in which man indulges.

If this vast material interest is sufficient to restrict the senseless extermination of birds, justice has been done to the world of sentiment and to humanitarianism, to foster which is our bounden duty and task, not only as far as birds are concerned but in every sphere.

Both the material and the sentimental side of the question has been done justice to by the decrees of the two Hungarian ministers.

The most important feature of the case however, is that the cause of bird-protection has more need than any other of international cooperation to bring it to a successful issue. 
And that it is high time that the affair should be settled, is evident to everyone who is acquainted with the facts.

The phenomenon that species of birds which have from time immemorial built their nests at certain points of certain districts are disappearing, is becoming daily more frequent: so also is the phenomenon that particularly birds of passage that pass in spring never return, though the natural conditions of the respective points have undergone no essential change. The only natural explanation of this phenomenon is that the species of birds, flocking together, fall at once and without exception into the nets of the tribe inhabiting the particular district over which they pass, such tribe being ornithophage.

This fact seems to be proved by the Italian bird-markets, where particular species are generally on sale in large quantities simultaneously, a sign of their having come from the same region and of having been caught in masses at the same spot.

This fact alone justifies the question being treated as an international one; for the nests of these unfortunate victims were not on Italian soil. A further justification is afforded by the fact that the ordinary movement of birds takes place between the Northern Polar Regions and the Equator, thus touching practically every State. 




\section{Preliminaries.}

The mighty development represented by the XIX ${ }^{\text {th }}$ century as contrasted with preceding ages produced the most radical transformations in that part of our World which stands highest in point of intellect, the States belonging to the Temperate Zone.

The triumph of the inductive method, expressed in the fact that man, to ease his own existence and render it more beautiful and more comprehensive, has received or rather forced into his service those powers which in their inmost being he cannot conceive - I would mention merely electricity with its power of destruction, giving light, driving and transmission, - has transformed the whole world of reasoning and the whole material foundation on which present society stands and is developing.

The tradition which preserved or perhaps explained the first evidence of the power of steam, symbolised in the kettle, the lid of which the steam of the boiling water was capable of lifting, developed into JAMES WATT making the power of steam the slave of man in the form of a steam-engine, a power that has displayed its driving force in places where, in the opinion of older ages, no thought of such a thing could be entertained, thus incalculably extending its sphere 
of operation. Starting from this point, only a spark of genius was required for FULTON to invent the steamship and STEPHENSON a steam carriage, thus applying the force of steam to locomotion.

Hereby the way was prepared for the realisation of the superfluous industrial and agricultural products on a far vaster scale; and only a slight step was required to make the ruling tendency the production in large quantities of all commodities required for a conscious spread of commerce.

This tendency was accompanied by the production and development of the means or implements, particularly the construction of those machines so important in agriculture, which are designed to immeasurably enhance man's power, to replace the same with multiplied force or to render it dispensable in so far as man has become merely the guider and controller of the machines which do the real work themselves.

Side by side came the brilliant and effective series of creations destined to enhance production, with which, on the field of agriculture, the glorious name of LIEBIG is most intimately connected. A muiual and productive reaction may be observed in the case of agriculture and, in the sphere of its operations, of the recognition of the effects of natural forces which has led to the most important triumphs of mechanics, physics and chemistry.

In such circumstances it is not surprising, in fact it seems natural, that in the XIX ${ }^{\text {th }}$ century, particularly in the most highly developed States of Europe, there has been, and still is, a tendency to appropriate all territory that is only slightly adapted for agriculture, to transform any such territories as are fit for transformation and to place them at the disposal of intensive agriculture.

We know that the regulation of rivers has been undertaken 
principally with the object of gaining territory and that this point of view was the cause of the draining of inland seas and marshes; further we know that in more than one place forests and undergrowths have been sacrificed to this end.

Primitive agriculture has been gradually diminishing in extent, in wide districts it has entirely disappeared, particularly pasture and meadow husbandry; the latter, once the "nurse of the people", is absolutely a thing of the past.

The report which the Hungarian Ministry of Agriculture in 1904 presented ta Parliament, as a preliminary to the incorporation of the International Convention for the Protection of birds useful to Agriculture, characterises the spreading tendency of agriculture and its results in the following words:

„The tendency pursued was to gain ever increasing territory for agriculture strictly so called and its branches, i. e. corngrowing, meadow cultivation, gardening, the production of crops to be hoed and fodder etc. The greater part of the re-gained territory was taken from water, forests or pristine pastures; and as farming changed in great part according to the products, not only the general aspect but the nature of whole districts became transformed."

"The most striking and, from the point of view of economic interest, the most sensible change was in the relation between animals and the vegetable world. The equilibrium inseparable from the primitive state of Nature took another form not only in the new territories lately handed over to the cultivator but indirectly in other parts also."

"The disappearance of meadows due to the regulation of the rivers completely revolutionised the conditions of life of the animals which formed part and parcel of them, particularly the fishes and birds. The same is true of the draining of lakes and marshlands too."

"The extermination of primeval forests and the restriction 
of forestry to shorter circuits not only transformed the life of insects but had an effect on the conditions of life of birds too, particularly by depriving the birds of most value to forestry and agriculture of opportunities of nesting, above all by taking away the hollows."

"The intensive cultivation of the regained territory transformed the conditions of life of lower-grade animals too. As the quantity of each product increased, the number and quantity of its enemies increased also."

"The essential point of the whole transformation, as far as the relation between animals and the vegetable world is concerned, may be concisely expressed as follows: the increased dimensions of production naturally increased the number of organisms living on the products, while on the other hand the work of extermination and transformation deprived all those organisms (from the point of view of this sketch birds), which are prime factors in the protection of the products, of chances of nesting and consequently of propagating, in fact of subsistence."

Though this part of the report is a reflection of the state of things in Hungary in particular, there is no doubt that a similar state of things exists, more or less, in the other countries of our zone: it is moreover to be taken as concerned more particularly with those species of birds which are permanent inhabitants of the respective districts, $i$. e. do not depart for winter.

As for the birds of passage, the report continues as follows:

"The case of those birds useful to agriculture, which in winter leave the temperate and northern regions to hibernate in the districts of the torrid zone, returning only in spring, is quite different."

„During the departure and return they fly over various zones, pass through many countries, and, apart from the 
halts which offer opportunities of catching them in masses, their flying in flocks tempts men to throw his catching apparatuses in their way, using the victims as food and employing their feathers for industrial i. e. commercial purposes."

"Consequently birds of passage, in certain southern countries, form periodical "popular food"; and the number of victims that fall a prey is proportionate to the increase in the dimensions of the catching apparatuses that grow with the development of industry, while the perfection of the means of transport has done much to render the realisation of the booty easy."

"The transformation of the agricultural conditions already referred to has also had its part in diminishing the numbers of birds of passage, by depriving them of the requisites of peaceful nesting."

„The place of the birds of passage that, according to the season, wander from North to South and vice-versa, in the order of Nature justifies the international control of this phase of bird-protection."

It is quite natural that such a transformation of things produced results which, in the second half of the XIX ${ }^{\text {th }}$ century, had already made themselves felt in no small measure. Side by side with the humanitarian, often sentimentalistic protection of birds which was particularly prominent in Germany and was made part and parcel of a general protection of animals, the necessity of rational bird-protection, that had its mainspring in the economic i. e. material interests of man, began to make headway; this feeling was naturally most prominent in countries where the results of conditions favourable to birds, of which we have just made mention, had made themselves most felt. 


\section{Meeting of German Farmers and Foresters.}

The first movement was made by the German farmers and foresters. The excessive increase of the injury done by insects, the sensible decrease and the disappearance of birds compelled them to raise their voices. It was they who, in 1868. 1868, after their XXVI ${ }^{\text {th }}$ General Assembly, appealed to the Austrian and Hungarian Foreign Minister and begged him to use his influence to persuade both the Hungarian and the Austrian governments to join the other States in concluding an international agreement (Convention) for the protection of animals of value to agriculture and forestry.

Both the Hungarian and Austrian Ministry, when asked, agreed to support the request of the German farmers if the movement was restricted to the protection of birds useful to agriculture.

This suggestion began the movement for the international protection of birds, which, after many vicissitudes, after repeated revivals and decadence, has at last led to an international agreement (Convention).

But, before pursuing the historical thread of events that can be traced back to 1868, we must, on the principle, so incumbent on all historians, of "suum cuique", admit that the idea of rational bird-protection also found its birth in Germany. This fact is not surprising when we consider that the Germans have, from time immemorial, been fowlers, this passion of theirs being thrown into relief by so powerful a Monarch as the Emperor FREDERICK II, the "crowned fowler" (1194-1250), in his work entitled „De arte venandi cum avibus" which contains many remarkable and still valid theses.

This national, traditional inheritance includes the bird1777. protecting decree of Lippe-Detmold in 1777, that of Saxe- 
Coburg in 1809 and that of the Grand Duke of Hesse in 1809. 1837, which latter forbade the slaughter and sale of birds 1837 - specified by name - useful to agriculture and provided for the protection of nests and broods.

The first to treat the question on a scientific basis was EDWARD BALDAMUS, the contemporary and friend of the great Naumann and of the Hungarian J. Solomon Petényi, who, at Köthen, in 1845, presented a motion, that was "severely 1845. ignored", 1 to the first meeting of the German Ornithological Society. A year later, at the same place, the same motion 1846. was laid before the committee of the Saxon Economic Societies, and was shelved.

Ten years later - in 1856 - at the second General 1856. Assembly of the German Ornithological Society, BaLDamus repeated his motion, annexing a list of the useful and destructive animals in groups: this too was unsuccessful. So it is only the material loss following on the excessive extermination of birds that has at last, in our days, justified the attitude of BALDAmus.

And now for the history of the International Convention.

\section{The first steps.}

Acting upon the initiative of the German farmers and foresters and the reports of the Royal Hungarian and Imperial Austrian Ministers of Agriculture, the Austro-Hungarian Foreign Minister, as a preliminary step, called upon the diplomatic representatives of the Dual Monarchy to provide for a friendly reception of the cause of bird-protection by the respec-

${ }^{1}$ Liebe und Wangelin, Referatum, 1891. Budapest: and cf. the documents of the first International Ornithological Congress in the 1884 issue of the "Schwalbe ${ }^{\text {; }}$; appeared in a special reprint. 
tive governments, and, where bird-catching was particularly fashionable, to do their best to persuade the respective governments, in the interests of their own agriculture, to restrict the catching in masses as far as possible. This meant a wide expansion of the question.

The reports of our Embassies were most satisfactory, showing that the idea of bird-protection had found a favourable reception in almost the whole of Europe.

As far as Central Europe was concerned, the most important and at the same time most doubtful point was whether Italy and Switzerland would approve the idea? And these States were actually the first to make favourable statements.

As early as March 1869 the Italian Government declared 1869. its approval in principle; at the same time the Swiss Federal Council sent in a most propitious reply, declaring that it would be possible to persuade the Italian Canton of Tessin, where the protection of useful birds had not been practised and bird-catching en gros had long been the fashion, to join the movement, provided the Italian Government agreed to control Italian territory.

In June 1869 the French Government notified its approval, declaring, however, that the first necessity was to secure the support of Italy, Spain and Switzerland.

On the strength of these declarations there was every reason to belive that the consent of the Southern States of Europe was assured in principle.

In respect of the further steps to be taken, the Governments of Hungary and Austria, acting in concert with the Austro-Hungarian Foreign Minister, came to the conclusion that the protection of useful birds should not be provided for by international State contracts, as proposed by the German farmers and foresters in 1868, for the simple reason that the conclusion of State treaties implies longwinded nego- 
tiations and that, whereas the contracting States would have to accept the same word for word „en bloc", it might very easily happen that the Parliament of one or other of the States might reject one or other detail of no importance, a fact which would frustrate the whole movement or at any rate considerably delay the final solution.

It appeared, therefore, far more opportune to draw up 1871. certain declarations of principles in general clauses, to be adopted by the contracting States in the form of an agreement - Convention -, the said States binding themselves to carry out and enforce the protection of useful birds, as defined in the declarations of principles, in their respective countries.

In accordance with this decision, the Swiss Federal Council, in 1872, proposed the surnmoning of an international com- 1872. mission to draft the agreement; this proposition was seconded by the German Government. But the Commission never met, because the preliminary negotiations failed and the States which were called upon to join raised many objections.

Seeing that the dearth of game in Italy made the catching of birds in that country of prime importance as a means of subsistence for the lower classes, a fact which was naturally the chief obstacle to obtaining the consent of Italy to the movement, it was considered of the first importance to take advantage of the courtesy and goodwill displayed by the Italian Cabinet to obtain securities that the existing or threatened obstacles should be removed. To perform this delicate task one of the most prominent zoologists of the day, Ritter von Frauenfeld, the keeper of the Vienna Imperial Museum (at that time the "Naturalien Cabinet"), was sent to Florence to try to come to an agreement on certain points with Professor TARGIONI-TOZETTO, the delegate of the Italian Government.

After an exhaustive treatment of the subject, the two experts drew up the following articles: 
1. The destruction in any place, in any manner and at any time, of nests or of eggs or of broods - except of such birds as are noxious to man or to his domestic animals, to the crops, products and dwellings - shall be forbidden.

2. The shooting season shall be restricted within certain limits, the open season, with respect to customs and public opinion, to be determined, either by law or parish administration, as lasting from Aug. 15 to February 28, i. e. from the beginning of autumn to about the end of winter. Shooting at any other time shall be rigorously prohibited.

3. Any kind of bird-catching with nooses, with spring-rods, with traps, with permanent large nets (Roccolo, Roganja?), with lime, with or without little owls, to be forbidden.

4. Licenses and special arrangements to be provided for the hunting of wild animals (garne) that are a danger to man and his domestic animals; in the case of services to be rendered to science, there shall be no difficulty in obtaining a license. In these cases there are to be no restrictions of time or manner.

5. Special regulations shall be made for the control of the shooting of waterfowl living on banks and marshes, the open season to be from the beginning of spring till the end of March.

6. The sale of nests, eggs and any kind of brood, however acquired, during the close season, shall be prohibited.

These six articles were made the subject of exhaustive treatment by the Imperial Austrian Ministry of Agriculture, which made some modifications. The modified articles were communicated to the Royal Hungarian Ministry of Agriculture; after the latter had approved them, the Austro-Hungarian Foreign office returned them to the Italian Government with a request for their acceptance. 
The text of the six modified articles was as follows:

1. The catching and killing of noxious birds is allowed at all times.

Other birds may not be caught or killed from the $1^{\text {st }}$ of March to the $15^{\text {th }}$ of September of any year.

2. The destruction or taking of the nests and eggs of birds living wild (except those of noxious birds) is forbidden.

3. The catching of birds with nooses (au lacet), with springrod (au largon), with traps (au trébuchet), with permanent large nets (aux grands filets) e. g. with the Roccolo, Roganja or Paretaio, particularly with the quail-catching nets, with birdlime (à la glu), with or without little owls (avec ou sans chouette) is prohibited.

4. The employment of insect-eating birds as decoys is forbidden even in permissible methods of bird-catching.

5. For catching or killing for scientific purposes exemption from the general regulations is permissible only on special request being made.

6. The sale of live or dead birds during the close season is forbidden.

These articles were received with much hesitation in Italy, and all good intentions of the Italian Government were in vain; the feelings of distaste were unconquerable. The prohibition of the permanent large nets, so well adapted for the capture of birds in masses, excited particular disfavour. 
The International Economic Congress at Vienna, 1873.

Negotiations were still proceeding when the World's Exhibition of 1873 opened at Vienna, providing an opportunity 1873. for the holding of International Congresses of various branches. These brilliant gatherings of experts included the International Agricultural Congress that met in Vienna on September $19^{\text {th }}$ and, sitting till the $23^{\text {rd }}$ of the same month in the presence of many of the first authorities, treated as of prime importance the following question: ${ }^{1}$

„What measures are required for the protection of useful birds ?"6

The first speaker was no less important a man than Dr. Tschudi, the legate at Vienna of the Swiss Federal Council and a deservedly famous natural historian, who, in the course of his scholarly lecture, warmly advocated the protection of useful birds. Similar resolutions, though differing in points of detail, were proffered by ALFRED BREHM of Berlin, Blomeyer of Leipsic, Settegast of Proskau (all Germans), Alexander Middendorff of Russia, and Marenzeller of Austria, etc.

The Congress met under the presidency of JOHN RITTER DE Chlumetzky (today be is Baron), the then Austrian Minister of Agriculture. Vice-Presidents were M. BoITEL, Controller of Agriculture, of Paris, A. MALTZAN, hereditary Chief Chamberlain, of Berlin, WeŠniAKoff, State Councillor, of St. Petersburg, and Count Francis Zichy, P. C. of Budapest

The first meeting was held on Sept. 19. 1873; its subject the protection of birds, the first speaker, as already menti-

${ }^{1}$ Compiled on the basis of the ${ }_{\text {}}$ Resume des déliberations et décisions du premier Congrès international agricole et forestier". Vienne 1874. 
oned, being Dr. FREDERICK TSCHUDI. The main features of his lecture were as follows:

It were very desirable to come to an agreement concerning the protection of birds and he hoped they would do so. His conviction was that every useful bird was to be afforded special protection with the exception of those already protected by the Game Laws. The latter, however, were not quite satisfactory in their regulations concerning shooting: e. g. in the case of the woodcock, the shooting of which was allowed in spring, a time when the greatest forbearance ought to be shown it, or of the willow grouse, the shooting of which was allowed just at pairing time.

We ought to know which are the birds protected by Game Laws; but in this respect neither the laws of the various States nor the handbooks offer any enlightenment. In particular the regulations concerning "small birds" were of such a type that they might be referred to all species.

Every year millions of little birds, of great value to agriculture, wandered into the stomachs of gourmets.

Consequently the first duty were to decide which birds might be hunted for?

The speaker proposed the formation of an international committee, whose resolutions might serve as a basis for the Parliaments of the several countries. This committee could compile a list of useful birds, employing the Latin names. It must be remarked, however, that the views concerning many species were divergent, e. g. in the cases of sparrows and starlings, which species, in the nesting season, consumed insects and so made good a hundredfold all the damage caused by them in the fields.

The speaker's opinion was that above all insect-eaters ought to absolutely protected against sportsmen and birdcatchers. Of course these species included the favourite song- 
birds; but bird-fanciers could make good their loss by having recourse to the not purely insect-eating species of Southern climes.

Those birds that were not exclusively insect-eaters should be protected by the introduction of a close season.

The best plan would be to fix the open season as lasting from September $1^{\text {st }}$ till the end of February, with possible extension till the $1^{\text {st }}$ of April.

Bird-catchers should be forbidden to use tools which break or kill the birds, that the useful ones might be picked out and set free.

But not only the birds, broods too must be defended.

There should be a control over the markets. The destruction of harmful birds should be entrusted to sportsmen or officials.

Collections made for scientific purposes could be allowed by special license. Special importance should be attached to imparting a knowledge of the various species in the elementary schools.

TSCHUDi's motion was the following:

I. The birds included in the Game Laws should be excluded from the agreement, seeing that they were a priori defended by the Game and Special Laws of the various countries.

II. An international committee should be formed, to compile a list of birds included in the Game Laws as well as of those not included in either Game Laws or handbooks and in general styled "little birds": the expert members of the Committee should define these birds and point out which of them could be hunted after or shot.

III. The Committee should compile a list of birds useful to agriculture and forestry, giving their Latin names 
too; this list to be included in the agreement (convention).

IV. The shooting or catching of any bird living exclusively on insects should be absolutely forbidden.

V. As for birds which live on seeds as well as insects, and are therefore of less value, there should be permission to shoot them from Sept. $1^{\text {st }}$ till the end of February. Strand and water birds should be protected by a close season lasting till the end of March.

VI. Catching with nooses, traps, permanent nets (Roccolo, Bagnaja[?]) and bird lime should be prohibited. Later on it could be decided with what instruments catching could be permitted without injuring the birds, thus rendering feasible the selecting and setting free of useful birds.

VII. The destruction of nests as well as the taking of broods and nestlings should be prohibited.

VIII. Trade in birds living exclusively on insects, whether dead or alive, should be forbidden at any time: the same rule to hold good for the other birds, except during the open season. To ensure this being carried out, a stricter control of the markets should be set on foot. The prohibition to include not merely the birds but their nests and broods as well.

IX. The destruction of noxious birds should be entrusted to sportsmen and to persons appointed by the authorities. Licenses for collections made in the interest of science to be given to certain persons.

MARENZELLER (of Vienna) approved of the idea of the Convention: but pointed out that whether the Convention could fulfil its purpose depended on the attitude of the Southern States. He considered that every bird ought not to included, and that an absolute prohibition of shooting was 
not advisable, for in that case it was possible that the Southern States would not accept the Convention. Further it was not advisable to disturb to too great an extent the harmony of the existing laws; it was not expedient to lay hands on the Game Laws, for in this respect very diverse measures were in force in the different States, while in some States the question of fowling was regulated not by the Game Laws but by special legislation.

Consequently the Convention should include the following points :

1. The destruction or catching of those insect-eating birds to be included in a list to be compiled should be absolutely prohibited.

2. The catching or shooting, except in breeding times, of those birds which live on insects and seeds and are therefore of less value to agriculture, should be permitted.

3. The destruction and extermination of the nests, broods and nestlings of birds known to be useful should be forbidden. A list of noxious birds should also be compiled. 4. Of the methods of catching, bird-lime, snares and every form of trap should be prohibited.

In support of his motion, the speaker maintained that birds were killed either for sport or for consumption; but even if both points of view were admissible, insect-eaters could be made an exception of. For, whereas seed-eaters fly in large flocks and consequently offer bird-catchers plenty of material, insect-eaters only form small groups and are, consequently, catchable only in small quantities: they are, therefore, of less importance than seed-eaters even from the point of view of consumption. ${ }^{1}$

I Italian gourmets, however, make sharp distinctions between insecteaters and esteem a dish of warblers above any other species. O. $\mathrm{H}$. 
The lists should include not merely the scientific but also the popular names.

The useful and the noxious birds should be included in two separate lists, for a comparison of the two lists would be enough to make clear which were indifferent birds, though being under protection during the time of nesting etc.

As far as the use of bird-lime, snares and traps was concerned, the use of the same should be forbidden in general, for they were a continual menace to insect-eating birds as well.

MARENZELLER's motion was as follows:

1. The killing, catching or destruction of birds included in List A) should be forbidden at any time and in any manner.

II. The catching of birds that live for the most part on seeds should be allowed at any time except from March 1 . till the end of August.

The use of bird-lime, nooses and every kind of trap to be absolutely forbidden.

III. The destruction of the nests, eggs and nestlings of all species except those included in List $B$ ) to be forbidden. This prohibition applies to the public or private sale of nests and broods.

To his motion MARENZELLER annexed the following two lists :

\section{List $A)$. \\ Useful Birds.}

Wryneck. - Yunx.

Woodpecker, 8 species. - Picus.

Cuckoo. - Cuculus.

Roller. - Coracias. 
Nightjar. - Caprimulgus.

Alpine Swift. - Cypselus melba.

Common Swift. - Cypselus apus.

Swallow, 4 species. - Hirundo.

Flycatcher, 4 species. - Muscicapa.

Crested Wren, 2 species. - Regulus.

Titmouse, 8 species. - Parus, sensu ampl.

Nuthatch. - Sitta.

Wall-creeper. - Tichodroma.

Tree-creeper. - Certhia.

Wren. -- Troglodytes.

Thrush, 2 species. - Turdus.

Accentor, 2 species. - Accentor.

Wheatear, 4 species. - Saxicola.

Warblers, 29 species. - Sylvia etc.

Wagtail, 4 species. - Motacilla.

Pipit, 3 species. - Anthus.

Lark, 3 species. - Alauda.

Finch. - Fringilla.

Starling. - Sturnus.

Jackdaw. - Corvus monedula.

Rook. - Corvus frugilegus.

List $B$ ).

Noxious Birds.

Bearded Vulture. - Gypaëtos.

Vulture, 2 species. - Vultur.

Falcons, 8 species including Kestrels. - Falco etc.

Eagles, 9 species. - Aquila.

Kite, 2 species. - Milvus.

Goose Hawk. - Astur.

Sparrow Hawk. - Accipiter. 
Harriers, 4 species. - Circus.

Snowy Owl. - Nyctea.

Eagle Ow1. - Bubo.

It must be admitted that MARENZELLER's motion included all the elements necessary to the feasibility of the creation of the subject matter of an international Convention, after due discussion; and the President declared that the motion should be made the subject of deliberation as laid down by the statutes of the Congress.

A. E. ВREHм was of opinion that, schismatically taken, it would be found that the decrease in the number of birds was not a result of the destruction of nests or of the use of bird-lime, nooses and traps. He referred to Gloger, who in one of his writings said that no change could be made in the progress of virgin nature, and if, for example, a plague of mice should overtake us, this would not be the work of nature but of ourselves. But had Gloger seen, as he (BREHM) had, how millions upon millions of insect-eating birds (including two species considered noxious) as well as at night the bats, make havoc of the masses of locusts that covered everything, he would not have maintained his thesis nque s'il n'y avait personne, qui échenillât les arbres, il n'existerait pas de chenilles."

The cause of the decrease in the numbers of birds is to be found in the present system of agriculture.

In extensive districts we grow vegetation on which insects can better subsist and increase; on territory stretching for miles we plant certain trees as if we were voluntarily assisting the insects, the propagation of which is so large dependent upon the same. We cut down every solitary tree, wipe out primeval forests without considering that, by so doing, we are destroying the homes of birds. We do not like the crow any 
more, because its cawing is disagreeable and we misunderstand its usefulness.

It is not the catching of song- and insect-eating birds that decreases their numbers but our destruction of their homes.

BREHM objected to radical measures but accepted the opinion of the President, viz. that "the law is nothing if we are unable to execute it".

BREHM proposed the following measures:

Every wooded place, whether small or large, should be preserved as the refuge of birds. Particularly old trees must be tolerated.

Special protection must be accorded to the starling, for, though noxious in vineyards, it can easily be scared away from them: but in respect to insects this bird is of more value than the rest put together, with the exception only of the titmouse and the yaffle.

Everywhere there should be bushes, shrubs, trees, hedges as protection for birds.

Better protection should be afforded to the crow as well.

It is extremely difficult to decide which species of birds are useful and which are noxious. No-one can be surprised at the owner of pheasantries shooting crows, which there act as nest-robbers. Neither the griffon vulture nor the kestrel ought to be put beyond the pale of the law because the former occasionally pounces on a sickly lamb or a straggling goat, while the latter, which is a mouse-destroyer and insecteater as well, occasionally robs the nests of small birds of fledglings.

BREHM accepted the III rd Clause of Tschudi's motion, that viz. referring to the appointment of an international committee with the object of classifying useful and noxious birds and preparing lists to be included in the international convention. 
In concluding his speech, BREHM advired the inclusion in the scheme of popular teaching of some means of acquainting the public at large with birds, for, in his opinion, no protection could be more effective than that resulting from an enlightenment of the masses.

He proposed therefore:

The compilation of a little book furnished with artistic pictures, to provide a knowledge of birds and plants, to be distributed, through the intervention of the respective governments, among clergymen, foresters, the heads of institutes and other persons who could impart instruction to young people: the distribution should be gratis.

StRATEN-PonthOZ, of Belgium, agreed with BreHM and emphasised the fact that in Belgium there were laws and regulations for the protection not only of birds but of useful mammals too (e. g. the mole).

BlomEyer, of Leipsic, supported the appointment of a committee and proposed the following points:

1. The protection of useful birds to be the duty of the State.

2. The laws should be modified to meet the progress of civilisation.

3. The Committee should sit at once and communicate its decisions to the Austrian Minister of Agriculture, who should notify the respective governments of the same.

Bossi-FEDRIGOTTI, of Rovereto, approved of the idea of classification. Useful birds should be protected, the taking of the others should be allowed; the time for taking, however, should be limited.

Though he too emphasised the agricultural point of view, he pointed out that, since in Italy, owing to a lack of forests, there was no shooting, the population could not be absolutely forbidden to catch birds. Prohibition was all the more 
difficult as the fowlers had hardly knowledge enough to discriminate between birds. ${ }^{1}$ The solution of the question of usefulness in a general sense was difficult. There were birds which, while at home insect-eaters, on reaching Italy destroyed fruit and olives. Such birds were useful at home, but in Italy distinctly noxious.

He did not believe in the decrease of the number of birds, at any rate at the hand of man. Of the many hillions of birds only an insignificant proportion fell victims.

He proposed the following points:

1. The taking of useful birds should be prohibited the whole year round. The taking of seed-eaters should be allowed from Sept. 1 till Dec. 1.

2. The authorities, teachers and clergy should take care that no-one destroyed birds' nests and that the natural historical knowledge of birds was spread.

TORELLI, of Rome, declared that in Italy the open season needed to be regulated uniformly.

Settegast, of Proskau, pointed out the difficulties in the way of carrying out the decisions. No-one had wished to put the decisions of the German Agricultural and Forestry Congress into force.

His proposal was, that the Austrian Government be requested to conduct negotiations that would render feasible the creation of an international convention for the protection of birds useful to agriculture.

KARGL, of Linz, declared that every effort which did not secure the support of Italy would be useless and unsuccessful. He described the fowling methods in vogue in Italy, among

1 This is the greatest error imaginable and remarkable in the mouth of an Italian. Italian fowlers can discriminate species of birds most nicely, for the prices of the bird-market vary according to species.

O. $\mathrm{H}$. 
others that with little owls and the Roccolo etc. He disagreed with BREHM, stating that the old trees could not be tolerated in forestry, for they produced masses of insects (!).

His motion was:

1. That the close season in Italy - at present the open season lasted from July 20 till April 8, an abnormally long time - should be prolonged.

2. That the price of a game licence should be raised, and, finally,

3. that national history should be taught in the schools.

MidDENDORFF, of Dorpat, pointed out the difficulty of defining usefulness and noxiousness. One State was situated on the $60^{\text {th }} \mathrm{N}$. latitude; another below $30^{\circ}$ - where, then, was the feasibility of uniform regulations? Starlings were in one place useful, in another noxious. This fact accounted for the diversity of views - how could they be reconciled? He pointed out that, in 1872, the ornithologists met in Germany and were of opinion that every State should decide which were the birds that were primarily useful, which the primarily noxious ones. He endorsed SETtegast's proposal that the Austrian Government should be requested to carry on negotiations with the various States and approved of the idea of every State appointing a committee to attempt to solve the question. These committees would supply a number of points that might lead to the accomplishment of a general agreement.

Such points had already been touched upon, and he had no doubt that the President would recapitulate the same.

With this the discussion was concluded, and the President asked the following gentlemen, viz. Messrs TSCHUDI, MARENzeller, Brehm, Blomeyer, Settegast and Middendorff, to form a committee with a view to harmonising the various proposals. 
At the next meeting Tscriud in the name of the Committee proposed the following compromise:

„The Congress of Agriculturists and Foresters moves that the Imperial Austrian Government be requested to secure the protection of birds useful to agriculture by means of treaties to be made, on the basis of the following points, with the other States of Europe;

I. The taking and killing of insect-eating birds shall be absolutely forbidden.

II. It were desirable that a committee to be composed of international experts should compile an accurate list of the birds to be protected.

III. The taking of birds living for the most part on seeds to be allowed, except during a close season lasting from March 1 till Sept. 15.

IV. Fowling with snares, traps and bird-lime to be absolutely forbidden.

V. The taking of eggs and nestlings as well as the destruction of nests (except those of noxious birds) to be prohibited. The compilation of the list of noxious birds to be the work of the Committee.

VI. The sale of insect-eating birds, either alive or dead, to be forbidden, that of other birds also during the close season: this prohibition to be extended to birds' nests and eggs.

VII. Exceptions may be made in cases of scientific requirements and in other special cases.

The course of the discussion has clearly proved that the defective knowledge of the modes of life, but in particular of the feeding, of the various species of birds rendered harmony of opinion, even among the expert ornithologists, impossible; the point of divergence, a divergence that must in the future only increase, is the list of birds and the applications of the conceptions of usefulness and noxiousness 
to the various species of birds. The difficulties are enhanced by the fact that it will be necessary to put an end to, or at least attempt to root out, the catching in masses of small birds, a custom in vogue in the States of Southern Europe, particularly in Italy, a custom, moreover, that, while deeprooted in the inclinations of the respective peoples, is of vital importance to their subsistence".

The Imperial Austrian Minister of Agriculture found that the seven points brought forward as the proposal of the International Congress for 1873, formed a suitable basis for the creation of an international convention between the States interested.

And in May, 1874, the Royal Hungarian Minister of Agri- 1874. culture too found that the seven clauses were a suitable basis for negotiations.

Here we shall do well to throw various moments into relief. Notwithstanding the opinion expressed in previous negotiations (e. g. in 1871.: v. supra), viz. that the "treaty" form, on account of its difficult and delicate nature, should be abandoned, the introduction to the seven points in question decided in favour of the conclusion of a Convention to be based on "treaty“ points and not points resting on decisions in principle: this may, however, have been nothing but a lapse in terminology, and, while otherwise unessential, was only the result of opportunism.

Of far more importance were $\S \S 2$ and 5 relating to the compilation of schedules of useful and noxious birds, which were important for the simple reason that they implied a confession on the part of the experts that, up till 1873, the negotiations had not been conducted on a regularly defined basis, since, in actual fact, there had been mention only of "birds", „small, useful and noxious birds", without any specification of the particular species. 
Yet the harmonising Committee could only come to an agreement by leaving out MARENZELLER's list, which merely required sifting. It may be that the temporary harmonising committee preferred to leare the matter to the international committee; buth the latter was never formed. This fact greatly reduced the practical value of the points.

But to proceed: it is a well-known fact that Count Gyula ANDRÁSSY became Austrian and Hungarian Foreign Minister 1875. in 1874. His wisdom is shown in the fact that, even before calling upon the States of Europe to consider the seven points, he attempted to come to an agreement with Italy which, though its geographical position and the tendency of its people rendered it of prime importance, had not accepted the points of the Vienna Congress: a basis for the negotiations was offered by the points of the agreement come to in 1872 by FRAUENFELD and TARGIONI-TOZETTI. His efforts were finally crowned with success, an agreement in the form of a "Declaration" being come to by the Governments of the Hungarian and Austrian Monarchies on the one hand and the Government of Italy on the other. This Declaration, which was signed by Count Gyula ANDrássy at Budapest on Nov. 5, 1875 and by Visconti VenOsta at Rome on Nov. 29 of the same year, contained the following stipulations:

\section{Declaration.}

$\S 1$. The governments of the two parties to this contract bind themselves to create, through their respective parliaments, strict and comprehensive legislation with a view to securing the protection of birds useful to agriculture, at any rate within the limits prescribed by the following clauses.

$\S 2$. The destruction of nests and lairs, the taking of eggs, the fowling of small birds shall be absolutely forbidden. 
At the same time it is in general forbidden to sell nests, eggs and nestlings procured in defiance of the prohibition.

$\S 3$. Further the prohibition of the following acts is declared:

a) The catching or killing of birds at night with birdlime, nets, guns or other weapons. Night is the period between one hour after sunset and one hour before sunrise.

b) The catching or killing of birds so long as the ground is snow-covered.

c) The catching of birds on river banks, at springs or on the banks of lakes, in times of drought.

d) The catching of birds by the strewing of seeds mixed with narcotics or poisons or with other baits.

e) The catching of birds with nooses, nets or any other implements used on the surface of the ground, such as traps, snares, the Dalmatian "plocke“ or the "lanciaxera" used for snaring larks.

f) The catching of birds with the „parexella" or indeed with any other style of moving, movable nets or such as may be spread on the surface of the ground, in fields, on bushes and shrubs or on roads.

The governments of the parties hereby contracting reserve to themselves the right of prohibiting the catching of birds in any other manner, if the reports of experts deputed by Austria, Hungary or the Senate of the Italian provinces prove that the methods in question are particularly destructive and harmful to the birds of the respective territories.

$\S 4$. Recapitulation. Apart from the restrictions of $\S \S 2$ and 3 , the catching or killing of birds shall be permitted only in the following manner:

a) From Sept. 1 till the end of February, with guns.

b) From Sept. 15 till the end of February, in any other way not prohibited. 
The sale of birds except during these periods shall be prohibited.

$\S 5$. Under certain conditions, by special request, if such request be justified, the respective government may allow exemption from the regulations of $\S \S 1,3$ and 4 , in the interest of the furtherance of scientific research.

$\S 6$. As, according to $\S 1$, the only object of this declaration is to protect birds useful to agriculture, it goes without saying that $\S \S 2-4$ do not apply to domestic or field farming nor to the farmyard.

Though the regulations of $\S \S 2$ and 5 do not apply to birds that, from an agricultural point of view, are not decidedly useful or noxious, if the latter are of some value at least as game, the respective governments are inclined to take measures to protect such species as game.

$\S 7$. The governments of the contracting parties shall inform one another of protective measures taken in their respective States and shall give all information that may be necessary or desirable.

$\S 8$. The governments of the contracting parties shall use every effort to secure the collaboration of other States.

$\S$ 9. The present declaration shall be drawn up in two copies of identical text and signed by the Foreign Ministers of the respective parties, one copy to be kept, after mutual signature, by each of the signatories.

(Signed)

COUNT ANDRÁSSY.

Budapest, Nov. 5. 1875.
(Signed)

ViscontI VenOSTA.

Rome, Nov. 29. 1875.

Had this important agreement come into force, the extreme significance of Italy in the question of international birdprotection would have enabled the greatest impediment to be surmounted: and those who were responsible for it, were 
convinced of complete success as well as of the fact that its coming into force would exercise a moral pressure on the other powers interested.

But to proceed: the two signatories agreed that an agitation should be carried on in favour of the declaration in the form of a protocol, the contents of which were as follows:

\section{Protocol.}

The ...... Government, having been requested by the Governments of Austria and Hungary on the one part, and by that of Italy on the other, to endorse the agreement for the protection of birds useful to agriculture come to between the three aforesaid States, declares itself ready to accept this proposal; and its delegates (viz. Messrs.....), who met today and endorsed the following declaration of acceptance, are prepared to sign the following mutual agreement:

$\S 1$. The ..... Government endorses the declaration come to between Austria, Hungary and Italy, rê the protection of birds useful to agriculture and signed, on behalf of the one party, at Budapest on November 5,1875 , on behalf of the other party, at Rome on November 25, 1875, the said declaration being annexed to the present protocol and constituting the integral part of the same; the said Government, moreover, submits to every duty and claims every right that concerns the parties agreeing; it reserves to itself the right of adapting the prohibitions of fowling $(\S 3)$ to suit the requirements of its own respective territory, without however detracting from the value of the restrictions contained in $\S 3$ of the Declaration necessary to the attainment of the ends in view; and reserves to itself the right of creating regulations more severe than those contained in $\S 4$ of the Declaration concerning the close and open seasons.

$\S 2$ Austria, Hungary and Italy accept this declaration of 
endorsement as well as the reservations contained therein, and at the same time engage to provide the signatories with all the rights and advantages secured by the Declaration.

$\S 3$. As, however, there are doubts concerning the meaning of the phrase "small birds" used at the end of the first paragraph of $\S 2$ of the Declaration, by unanimous agreement the word "small" shall be replaced by "nestling.“

In certification of which the undersigned, conscious of the trust deputed to them, have signed and sealed with their official seals, as plenipotentaries, the above protocol.

Signed etc. etc.

There can be no doubt that the above agreement as expressed in the two foregoing documents, even in the published form, was a remarkable result, considering that in Italy the catching of birds - let us add of birds migrating according to seasons - is a custom deep-rooted among the people, one that, according to the season, implies food for the masses.

We shall soon see why it was unsuccessful. It is, however, beyond doubt that, in the cause of bird-protection, considering the special circumstances just mentioned, the declaration was epoch-making, for it created a firm frame suitable to receive regulations inspired by a better insight, the result of experience, and aiming at a rational protection of birds.

\section{Developments.}

The Austro-Hungarian Foreign Ministry saw, in the De1876. claration of 1875 and the protocol organically connected with the same, an excellent basis for the extension of the agitation to cover all the States of Europe. The action was begun in 1876, when an appeal was made first to Germany and 
France, then to Switzerland, Belgium, Holland, Russia, Spain and Greece.

The progress of the agitation is most clearly illustrated by the report delivered by László SzÖGyény, then chief of the Hungarian Department in the Austro-Hungarian Foreign Ministry, to Count ANDREW BeTHLEN, Minister of Agriculture in Hungary, on April 7. 1890, sub No. 1859/9. A. ${ }^{1}$ The pith of the report was as follows: "The negotiations with the various States have made very slow progress, because the great majority of the same avoided giving a binding promise, saying that, before they could do so, the way for the same must be levelled in their respective Parliaments, and that, before the particular laws were passed, any international agreement on the subject would of necessity be a dead letter. We know that the appeal resulted in a definite declaration of endorsement only from France and Switzerland, the former very warmly supporting the idea of an international convention. The governments of the great majority of the other States made their decision dependent on the attitude of Germany, where the Reichstag was considering the draft of a Bill to provide for the uniformity of the regulations for the protection of birds all over the Empire; they all considered that no decision could be arrived at till this Bill had been passed".

„Belgium evaded the question just as Germany had done; while Russia used evasive expressions to avoid accepting the invitation".

In a later stage of the negotiations, all the Northern States, with the exception of Great Britain, ${ }^{2}$ were requested to join

${ }^{1}$ Chief Report of the Secund International Ornithological Congress held at Budapest. Budapest, 1892, p. 64.

2 The conditions in Great Britain, apart from its insularity, are peculiar, as we shall see later.

O. $\mathrm{H}$. 
the movement, a course which resulted in nothing but the interchange of notes.

"As the creation of an international convention without the co-operation of Germany, (especially considering her central situation), was impossible, it is quite natural that the hesitating attitude of the German government hindered further development and necessitated the postponement of further negotiations until the raising of the German Bill for the protection of birds to law, when the cooperation of the German government could be reckoned upon. But the passing of the German Bill was unexpectedly delayed, for several drafts were elaborated without the two Houses of the German Legislation being able to come to an agreement. While these negotiations were going on, any further development of the international protection of birds became impracticable". So much for the first part of the Report.

We must inquire at this point: what was the underlying cause of the hesitating, vacillating attitude of the States? Not one gave an absolutely definite refusal; while three large States, Hungary, Austria and Italy - the latter the most fastidious of all - were unconditionally in favour of a convention based on the Declaration.

The cause was deepseated and prevented the States a priori from undertaking, with a quiet conscience or rather on the basis of absolutely objective knowledge, a binding convention. The consciousness of uncertainty, as concerning the cause, was not clear in some cases; but it was there and made itself felt.

Today it is easy to solve the riddle, for the development of the cause, the moments of which are now well known, offers a voluntary solution.

We know that the International Congress of Farmers and Foresters met at Vienna in 1873, at which the question of 
bird-protection was treated in the presence and with the assistance of several leading ornithologists (V. supra).

We know, further, that this Congress agreed on seven points and that of these points No. 2 ordered the compilation of a list of birds to be protected, while $\S 5$ arranged for the same to done with the noxious birds, i. e. just exactly what BALDAMUS saw to be necessary as far back as 1856, including it in his first draft. These two lists would have offered a solid basis for an endorsement later on of the international convention.

But, in the mean time, the Austro-Hungarian Foreign Ministry came to an agreement with Italy, which resulted in the "Declaration" of 1875 and the protocol attached; the lists of useful and noxious birds, however, were omitted; and this was the cause of the vacillation shown by the various States, which were only informed that "useful birds were to be protected, the noxious ones to be hunted down." The question as to which species were to be protected or hunted down found no answer either in the Declaration or in the protocol. Yet that was the point on which everything hinged.

To take up the thread of events again: time passed in barren negotiations without even any such result being attained as, in other circumstances, the renewal of Switzerland's proposal that an international conference should be assembled must have produced.

\section{The First International Ornithological Congress, 1884.}

Then occurred the event of 1884, the First International Ornithological Congress summoned to Vienna, that promised to be of importance or even decisive in the matter of birdprotection. This Congress figures in the list of Ornithological Congresses since held as „the most brilliant,“ a fact that is 
not remarkable when we consider that the active participation of the late Heir to the Hungarian and Austrian thrones, the Archduke RuDOLF, secured the attendance of nearly all the most prominent ornithologists of the time, who took a lively part in the discussions.

All the advanced States of Europe, with the exception of Great Britain and Spain, were represented, for the most part by ornithologists. Among the men present we find the names of E. Homeyer, Rudolf and William Blasius, E. Baldamus, Prof. Altum, K. Russ, Staatsrat Schrenck, the famous Russian traveller, E. OUSTALET, the distinguished Frenchman, Victor Fatio and Girtanner from Switzerland, Enrico Giglioli from Italy, Borgareve from Germany, PALACKy from Bohemia, G. RADDE, a famous Russian traveller, etc. etc.

Under such circumstances we cannot be surprised at the great expectations entertained far and wide, a fact which necessitates our reproducing in a more precise manner that part of the discussions which relates to bird-protection, if for no other reason, because they are extremely characteristic of the ruling tendencies and the conceptions of the leading men. Our report is based on the official minutes as reproduced in the 1884-85 issues of the "Schwalbe", a periodical then appearing at Vienna, though they were published separately as well. ${ }^{1}$

The Congress was opened on April 7, 1884 by the Crown Prince Rudolf in person; while the discussions were begun under the presidency of RADDE, Russian Councillor of State, and continued under the presidency of HOMEYER, SCHRENCK and Professor Rudolf Blasius.

At the first classmeeting the Congress at once entered

${ }_{1}^{1}$ Sitzungsprotocolle des ersten internationalen Ornithologen Congresses etc. Wien, 1884. Verlag des Ornith. Vereins in Wien. 1884. 
into the discussion of the international protection of birds. The proceedings were opened by an address by Dr. BERNARD Altum, one of the greatest authorities of the time, the famous Professor of the Academy of Forestry at Eberswalde.

The speaker, in addition to the agricultural significance of birds, emphasised their aesthetic value as well, creating an entire system in this respect, the scheme of which is as follows:

1. Aesthetic significance:

a) pleasant form.

2. Colour and shape: according to
a) zones,
b) seasons,
c) time of day,
d) habitation,
e) sex and age.

3. Movement, peculiar flight.

4. Musical powers:

a) mechanical (the pecking of woodpeckers, the piping of the common snipe),

b) organic (voice and song); according to

I. season,

II. time of day (2 categories, day and night singers),

III. surroundings,

IV. society,

V. relationship.

The essence and significance of bird-songs.

This immense perspective, the opening of which betrayed an absolutely German intellectual power, and was only loosely connected with the practical, i. e. the prosaic part of the bird question, did not have the effect on which its author reckoned. But he had something to say of the practical side 
of the question as well; as, however, he generalised several phenomena and weakened each proposition by the following one, his address was not convincing and was not instrumental in setting aside the antagonism that had long existed between the speaker Altum with his small following and E. Homeyer with his large following, and had often broken out most vehemently.

The antagonism between these two leading men, of such prominence in the German scientific world, owed its origin to the fact that while Altum judged birds from an aesthetic point of view as well and declared that woodpeckers were noxious, HOMEYer considered that birds sould be judged only from the point of view of usefulness and noxiousness and declared that woodpeckers were useful.

The pith of AltuM's reasoning was contained in the following resolution:

1. In considering the question of bird-protection, both the aesthetic and the agricultural significance should be taken into account. In most cases the latter should be decisive. In cases of great aesthetic significance trifling noxiousness should not be taken into account.

Birds figuring as game are subject to the regulations of the respective Game Laws.

Exceptions should be made for scientific purposes, in the case of very rare birds or for selfdefence.

2. Having regard to the principles adduced, all home species of birds (with the exception of winged game) should come under the law for the protection of birds, day birds of prey (with the exception of buzzards, roughlegged buzzards, lesser spotted eagles, kestrels, honey buzzards and red-legged falcons) to be excluded, as well as

Eagle Owls,

Kingfishers, 
Shrikes,

Finches,

Crows,

Coots,

Moorhens,

Herons,

and all swimming birds not figuring as game, by name merganseres, cormorants, terns, gulls, petrels, razorbills, divers and grebes.

Dr. Altum accompanied his resolution with explanatory notes, in which he remarked in the first place that the proposal was a negative one, and that it might be modified in many respects. E. g. among birds to be hunted down he had included all species of crows, whereas he had observed that the rook, in destroying the caterpillars of the Noctua graminis and popularis, was of decided value to reapers, besides being invaluable to ploughed land in that, while following the plough, it picked up the grubs: but it was also noxious in that it picked up the seed sown. Here was a case of usefulness and noxiousness in one: and so it was with finches etc.

This explanation and the particularisation contained therein, which was in part insinuatory, was the sign for the commencement of a detailed debate.

Altum's antagonist, E HOMEVER, at once found fault with ALtum's issue and declared war; his view was, besides, that there was no need to go into details, as such could not be thoroughly discussed within the time at the disposal of the Congress, and that they should content themselves with a discussion of general questions. ${ }^{1}$

${ }^{1}$ cf. E. F. v. Homeyer: "Die Spechte und ihr Wert in forstlicher Beziehung". Frankfurt, 1879. 
Let us now examine the series of proposals offered in the course of the debate. The brilliance of the occasion justifies the enumeration in detail; and only by such enumeration can the historian form a proper conclusion, in the interests of posterity.

Dr. PALACKY - and later on Victor FATIO - supporting their proposals with exhaustive arguments, proposed, the formation of an international committee (Vigilanz-Comité ${ }^{\prime}$ ) to control the carrying out of the protection of birds and to make a study of the question.

Dr. Russ's proposal was that "wild European birds not included in the regulations of the Game Laws should not be taken for food".

- Prof. TALSKY'S proposal or rather principle was "to let live what lives".

FATIO's proposal rê protection was:

„1. The taking of birds and migratory winged game to be forbidden from the middle of winter till the middle of spring.

2. The sale of birds killed or their eggs to be forbidden during the same period.

3. All catching apparatuses suitable for taking the birds in question to be absolutely forbidden; and the wholesale acquisition of such apparatuses, whether nets or anything else, with which similar results could be obtained, to be rendered difficult.

4. Except in justifiable cases, the traffic in useful birds to be forbidden at all seasons".

BorGgREve's proposal :

"The first International Ornithological Congress requests the Austrian and Hungarian Governments to take steps towards the creation of an agreement, based on reciprocity and uniting the States of Europe and North Africa, which agree- 
ment shall, with the binding force of law, decide that, in the first half of the calendar year, it be forbidden,

a) to traffic in any way with birds killed or caught,

b) the shooting of any kind of birds (except only capercailzies and black grouses) in so far as they are not directly noxious to agriculture, shooting sport or fishing, or secured by special licence of the authorities for scientific purposes".

PALACKy's proposal (the second):

"The killing of birds and the taking of their eggs shall be forbidden. The Parliaments of the respective States to define exceptions, especially

a) concerning birds of prey and those noxious to fishing,

b) concerning game,

c) concerning those which appear in masses, if not home birds,

d) concerning protection during the breeding season".

KERMENIČ's proposal:

"Taking birds with snares, narcotics and hooded birds shall be prohibited.

The taking of nests shall be permissible only for scientific purposes.

The supply of shrubs and roosts is desirable.

The cruel treatment of birds imported wholesale from abroad should, from a humanitarian point of view, be prevented".

Baron DunAY's proposal:

"The Ornithological Societies and observatories should try to get into touch with the governments of the various States and in this way further the passing of suitable, opportune laws".

E. BACHNER reminded the Congress of the fact that "the Russian Game Laws prohibit the shooting of insect-eating and singing birds all the year round, while they protect the 
capercailly, the black grouse and the partridge with a close season lasting from Febr. 15 till Aug. 1".

E. Homeyer reported that "in Japan the close season lasted from March 15 till August 15“.

Dr. Russ's second proposal:

"Considering that the question of bird-protection cannot be settled in the short time at our disposal, I propose that a permanent committee be appointed with instructions to prepare an accurately elaborated scheme for the next Congress or any other suitable occasion".

\section{Instructions.}

E. BALDAmus reported that he was instructed only to elaborate a schedule of useful and noxious birds.

EnRico Giglioli, the delegate of the Italian Government, announced that he had instructions to abide by the „Declaration" of 1875; consequently he should not participate in any other decisions.

These and other proposals naturally rendered it necessary to attempt harmonisation. After a long and very lively discussion, and after the opportunist points of view had been exhausted, the delegate of Switzerland, Victor FATIO, hit upon the form in which a successful compromise was at last effected. The text of the same was as follows:

„The first Ornithological Congress requests the AustroHungarian Foreign Minister to take steps for the creation of an agreement based on reciprocity or for the making of an international treaty which shall be binding on the States of the World ${ }^{1}$ and shall enforce the following principles:

I. The killing of birds in any other manner than with guns, the taking of the same, as well as the traffic in their

' Die Staaten der Erde“. 
eggs, shall be forbidden in the first half of the calendar year or in a corresponding period.

II. The wholesale taking of birds shall be forbidden at all times".

Before drawing a final conclusion we must remark that the Swiss delegate most nicely secured the interests of his own country when in his first proposal he protected the "gibiers de passage“, i. e. "migratory game“, for the first half of winter; and his object was the same when, in the text of the foregoing compromise, he limited the traffic to the first half of the year: in consequence thereof the transport through Switzerland of the bag of the wholesale quail-catching practised on the $\mathrm{N}$. coasts of Africa and in Southern Europe remained untouched as long as the traffic was in vogue. Equally interesting was BorGareve's proposal, which takes no notice of egg-taking, since in the Northern regions of Europe the wholesale taking of gulls' and lapwings' eggs has an economic significance.

If we take all the proposals and compare them with the geographical situation of the several States, with the consequent natural conditions and the effect upon birds, it will be perfectly clear that it is impossible to create any resolution, regulation or law that would be suitable everywhere; that, consequently, whether resolution or law be proposed, the States concerned must be allowed freedom of action in so far as the peculiar conditions of their respective countries require the general regulations to be supplemented with special legislation.

From this point of view, it is only natural that the compromise passed by the first International Ornithological Congress had no absolute result; its want of success was rendered still more inevitable by the fact that it did not decide which species were useful, which noxious? What modifications could the States have introduced? 
Another great fault of the Congress was that it did not take the preliminaries, i. e. the historical development of the cause, as its startingpoint, though it might very easily have done so at Vienna, the seat of the Austro-Hungarian Foreign Ministry which for years had directed the international negotiations and was responsible for the "Declaration" of 1875 (v. supra), by which, as Prof. Gigliou announced, his Government were determined to abide. This "Declaration", taken in connexion with the significant discussions and resolution of the International Agricultural and Forestry Congress of 1873, would have formed a fitting basis for the work of the first International Ornithological Congress, a basis on which it could have progressed and created. Instead of doing so, however, the Congress discussed organisations to comprise the whole world, organisations of which Dr. POLLEN, the delegate of Holland, very aptly remarked that they were mere suppositions and not things that could be practically realised.

The only practical result, therefore, was not the compromise but the proposal which desired the appointment of a committee with instructions to present or carefully elaborated scheme to the next Congress.

The Capital of Hungary, Budapest, was decided on as the scene of the Second International Ornithological Congress. Among ornithologists this Congress is known by the epithet of "the best prepared."

To arrange the preliminaries for this Congress should have been the task of the Committee formed at Vienna (the „Permanent International Ornithological Committee", abbreviated to "PIOC"); its duty should have been to create a network of observatories all over the world for the observation of birds. The international organisation of the protection of birds was also within the sphere of the Committee, since 
the first International Ornithological Congress had busied itseif most expressly with the question: consequently it goes without saying that the question in point could not be ignored at Budapest. Thus the question of the international protection of birds came direct to Hungary, whose government, as we know, had already, on more than one occasion, taken an active interest in the same.

\section{The question of the international protection of birds comes to Hungary.}

The Second International Ornithological Congress, to be held at Budapest, was also organised and should have been held under the auspices of H.I.R. H. the Archduke RUDOLF, heir to the thrones of Hungary and Austria. The organisation and preparation should naturally have been the work of the PIOC, especially the scientific part of the same: as for the question of the international protection of birds, its duty was to elaborate and then present the concrete proposals according to the unanimous instructions given by the first Congress.

Consequently all the Hungarians had to do was to take the particular local measures suitable to the occasion, including the scientific contributions which Hungarian experts and societies were ready to supply for the occasion.

The organisation was undertaken by the Royal Hungarian Ministry of Public Instruction in conjunction with the Royal Hung. Ministry of Agriculture. The initiative in organisation, however, undoubtedly belonged to the PIOC, which had received powers for that purpose from the first Congress, its creator. The said Committee was presided over by Dr. Rudolf Blasius, Professor at Brunswick, the celebrated ornithologist; the Secretary's office, however, was at Vienna, the Secretary 
being Regierungsrat Dr. HAYEK; its members were scattered all over the world.

The income of the Committee consisted of the contributions of the respective States: that of Hungary was 1000 florins $=2000$ crowns, a sum included, in equal shares, in the budgets of the Ministers of Public Instruction and Agriculture respectively. These contributions were sent partly to the President, partly to the Secretary, and were employed to cover the expenses of propaganda and the maintenance of the "Ornis", the periodical published by the Committee.

So it is easily understood that the Committee never met; the President and Secretary held communication only by letter, acted quite independently, and spent the money independently, facts which led to rivalry, later to a breach of unity that only the authority of the Crown Prince succeeded in smoothing over.

Under such circumstances the organisation could make no start or progress. The only thing that was done was to propose 1888 as the year for the holding of the Congress.

Finally, in 1887, the Hungarians made a move, by ela1887. borating a scheme for the PIOC, which the latter should utilise as a basis for the scheme it was to present to the Hungarian Government. The seven points of the Hungarian scheme proposed to provide for the delivery of special addresses. The members of the first special committee, were Dr. GÉZA Horváth, John Frivaldszky, Dr. Gyula Madarász, Prof. John Kriesch, Prof. Joseph Paszlavszky and Otto Herman, 1888. then M. P. At the same time Dr. Blasius and the Secretary's Office at Vienna were requested to present a scheme, keeping as far as possible to the seven points.

In the meantime the quarrel between the President and Secretary was raging, time passed away, and the year 1888 
had to be dropped, a course in which, in the spring of 1888 , the Crown Prince himself acquiesced.

Finally, in May, 1888, the Secretary presented the scheme for the Congress to the Hungarian Ministry of Agriculture, the said scheme being a transcription, with some additions, of the seven points of the Hungarian special committee, and proposed a sum of 10,000 florins $=20,000$ crowns, for expenses.

As the discords in the PIOC became more and more aggravated, the Hungarian Government, which had received notice of the same, thought fit to take steps to discover the opinion or even to request the decision of the Crown Prince RudOLF.

To this end the then Hungarian Minister of Public Instruction, Count ALBIN CSÁKy, requested the intervention of LÁszló SzöGyénY, Chief of Department in the Foreign Minister, adding that the year 1889 must be dropped and 1890 proposed as the year for the holding of the Congress.

LÁszló SzöGyÉNy fulfilled the request, and, after finding a fitting opportunity, on Jan. 9, 1889 communicated the 1889. following answer to ALBERT BERZEviczy, then Secretary of State in the Ministry for Public Instruction.

"His I. and R. Highness thinks it best that the Congress should meet in the autumn of 1889 or, still better, in the spring of 1890, for there is too little time until May 1889: then, again, we must not forget that the Paris Exhibition, opening in May 1889, will probably attract more than one expert to the French Capital. It is further desirable that the quarrel between Dr. Blasius and Dr. HAYEK be set aside. His Highness, in any case, takes a keen interest in the Congress and is ready to come to Budapest when the time comes and preside at the first meeting".

This answer was brought to the notice of Dr. HAYEK 
who, on Jan. 27, of the same year, replied in anything but a conciliatory tone.

The answer arrived a few days before the catastrophe at Meyerling: as soon as the news of the latter was published, the strong movement which the confessed readiness of the Crown Prince gave rise to suddenly ceased.

It seemed that the Congress had been indefinitely postponed.

But the request made to Dr. Blasius in 1887 had not yet received any answer; and it was his decision, which arrived on March 31, 1889, sub No. 185, that again set things moving.

The scheme offered by Dr. Blasius also adapted itself to the 7 points (1887) of the Hungarian Committee, only there were other points as well, already sanctioned by the Crown Prince, - e. g. the necessity for a draft of statutes and bylaws etc.

The last moment of this period was when the corporation of Budapest voted 4000 florins $=8000$ crowns, for the expenses of the Congress, a sum which, together with the 12,000 crowns offered by Government, was sufficient to secure the material basis.

Meanwhile the chances of the Congress fluctuated, for the simple reason that the Vienna secretary continually made difficulties and actually gave the Hungarian Ministry of Public Instruction occasion to think of dropping the affair altogether. ${ }^{1}$

But Hungarian experts could not reconcile themselves to

I In the official minutes of the Congress will be found the reason for the peculiar conduct of the Vienna Secretary : at the closing meeting the Congress did not vote its approval of the way the money entrusted to him had been spent. 
the idea at all, for the incapacity of the PIOC might have compromised the ability of the Hungarian scientific world in the eyes of those who could not see to the bottom of the affair. There was every reason why the Hungarian circles should take the organisation into their own hands, carry it out and merely inform the Brunswick President and the Vienna Secretary of the accomplishment of the various moments.

At a second private meeting of experts, OTTO HERMAN was requested to draw up a memorandum: the memorandum was drawn up and presented by Mr. Herman, who supported it by word of mouth, to Count ALBIN CSÁKY, the Hungarian Minister for Public Instruction, on Oct. 8. 1889.

Considering its motives, the Minister approved of the memorandum, and, while appointing IMRE SzALAY, of his own Ministry, to manage the administrative part of the work, requested the Royal Hungarian Natural History Society, or rather its President KáLMÁN SzILY, to take the first steps. Thereupon the Society entrusted the management to the following members, - Dr. GÉZA ENTZ (to act as Chairman) Otto Herman (as Secretary), Dr. Géza HoRváth and John FrIVALDSZKY. The Committee, by virtue of its rights, supplemented itself by inviting the aid of Dr. GyULA MADARÁsz, the only Hungarian member of the PIOC, while, later on, NÁNDOR (FERDINAND) BÁTHORY, Director of a Real-School (Modern School), joined as the delegate of the Corporation of Budapest. The Government was represented by IMRE SzALAY, Ministerial Councillor.

This Committee was formed on Dec. 31, 1889 and entered at once on the work of organisation.

It had already been decided that the final date for the Congress should be 1891; and the precise date was fixed later for Whitsuntide of that year. 
In accordance with the decision of the first meeting of the Committee, all the ornithologists of the country were 1890. invited to assemble on Jan. 19, 1890. Twenty-four in all put in an appearance and, under the presidency of JOHN Csató, the worthy Nestor of Hungarian ornithologists, at this their first meeting succeeded in completely ordering all the strictly scientific ornithological agenda of the congress.

A detailed description of the further progress of the organisation does not belong to an historical sketch; all such details may be read in the Chief Report of the Congress (pp. 17 seq.) ${ }^{1}$ there is only room here for such details as concern, either directly or indirectly, the Congress itself and the subdivisions of the same.

The Committee appointed by the Natural History Society completed all the arrangements, including the formation of the great National Committee. The latter appointed four executive committees, viz.:

I. Science Committee: Chairman, Otto Herman.

II. Economic Committee: Chairman, IzIDOR MÁDAY.

III. Correspondence Committee: Chairman, John Xanthus.

IV. Exhibition Committee: Chairman, John Frivaldszky.

The Science Committee agreed that, to secure the scientific results of the Congress, classes should be formed, and decided to procure the services as referendaries of the most distinguished representatives of the science of ornithology and the most prominent champions of the protection of birds.

The classes and the referendaries of the same were as follows:

1. Systematica: R. Bowder Sharpe, British Museum, London, Dr. A. Reichenow, Berlin, and Prof. A. Newton, Cambridge.

1 „Föjelentés. Hauptbericht. Compte-rendu. Hivatalos rész. Budapest, 1892." 
II. Biologia: Dr. és Sc. Emile Oustalet, Mus. Hist. Naturelle, Paris.

III. Anatomia: Dr. M. Fürbringer, of Jena (now at Heidelberg).

IV. Ornithogeographia: E. Giglioli, Florence, and PH. L. SClater, London.

V. Migratio: J. A. PALmén, Helsingfors.

VI. Ornithologia oeconomica: Th. LIEbE, Gera, v. WANGELIN, Merseburg, and IZIDOR MÁDAY, of Budapest. ${ }^{1}$

The Hungarian Scientific Committee was convinced that the formation of the classes and the appointment of referendaries, who were requested to treat of the position of the respective branches from the point of view of historical development, would give a firm and salutary basis to the discussions of he classes and enable the Congress to make the best use of the short time at its disposal.

This conviction was not misplaced, as among the reports there are works of lasting value.

The fourth (VI) Class, that of economic ornithology, combined everything relating to the economic significance of birds, including the question of international bird-protection as well, for the treating of which, with regard to the preliminaries and current tendencies, the services of three referendaries, as we see, were requested and secured.

The Congress open on Whitmonday, 1891. We may say that it was a brilliant success and deserves special mention as being the first occasion that Englishmen took part in an International Ornithological Congress held on the Continent.

R. B. Sharpe, the keeper of the British Museum, con-

1 These classes were later reduced to 4 , No. IV being that dealing with the current question of the protection of birds. 
fessedly the first systematician of the day, appeared in person to present his report.

All those who were asked to treat of the several questions sent in their reports, viz. Cordeaux, Sclater and NEWTON, of Great Britain, as well as the celebrities from other countries, FÜRBRINGER, the German anatomist, Giglioli, the Italian ornithogeograph, PALMÉN, the Finnish ornithobiologist and OustaleT, the French ornithologist.

Speeches were made in person by SHARPE, of London; Oustalet, of Paris; Wangelin, of Merseburg, and Reichenow, of Berlin; besides these there appeared in person, BisHop and Chadbourne (U. S. A.); Count Berlepsch, Rudolf and William Blasius, Otto Finsch, Baron KöNig v. WartHaUSEN, Russ, SchäFF, Schalow and Count ZePpelin (Germany); Baron D'Hamonville and RaOul (France); E. Middendorff and Büchner (Russia); Tschusi, Palacky, Grobben, Claus and Lorenz (Austria); Fatio (Switzerland); Collett (Norway); BütTIKoffer (Holland); Hartert (Great Britain); GHIORGIEFF (Bulgaria), etc.

Special addresses were delivered by Major ALEXANDER HOMEver ("on the birds of Africa") and Robert ColletT ("on the phenomena of the North").

President, by seniority, was Francis Pulszky: the Congress was opened by Count ANDREW BeTHLEN, Minister of Agriculture, and closed by Count Albin Cś́KY, Minister of Public Instruction, both of whom, with BENJAMIN KálLAY, Austro-Hungarian Finance Minister, were honorary presidents.

Active Presidents of the Congress were VICTOR FATIO and Otro Herman, the General Secretary was Dr. GÉza HorvátH. Details of the rest of the organisation will be found in the Chief Report of the Congress (v. supra). The administrative details here mentioned only serve to mark the form and importance of the occasion. 
We have to treat specially here of Class IV (VI), which almost exclusively discussed the question of the protection of birds.

The functions of the class were opened by Major-General Béla GHyczy de Ghicz and Assakürt, the delegate of the Hungarian organisation.

The class elected the following officers:

Chairman: AleXander Homeyer, Greifswald.

Vice-Chairman: JACOBY VON WANGelin, Merseburg.

Secretary: Gyula Szalkay, Budapest.

The other members of the class were: EdMUND SzENiczey, Budapest; Géza Koppély, Budapest; Zimmermann, Königsberg; ANDOR LÖCHERER, Budapest; Dr. Russ, Berlin; TISCHER, Augsburg; Lieut.-Colonel v. WOLFFERSDORFF, Sondershausen; TAeschlein, Augsburg; Dr. Fatio, Geneva; Zeller and Pallisch, Vienna; Talsky, Neutitschein; SeIdl, Bosewitz; Baron Berg, Strassburg; VAdÁsZfFY, Budapest; Count ZePpelin, Stuttgart; TAMÁsY, Budapest; Baron KÖNIG-WARTHAuSEN, Stuttgart; MiCHEL, Bodenbach; Dr. HORVÁTH, Budapest; G. Bıkkesv, Magyar-Óvár.

Addresses were given by v. WANGelin (in Prof. Liebe's name too) and IzIDOR MÁDAY.

The class at once entered into a discussion of the LIEBE-WANGELIN report, which took as its starting-point the resolution passed at the International Ornithological Congress held at Vienna in 1884 and then passed in review the measures in force in the various states of Europe for the protection of birds.

This review forms an organic part of the history of international bird-protection; so an extract of the same is in place here. ${ }^{1}$

1 Referat über den Vogelschutz, von Th. Liebe und v. Wangelin. Budapest. Separatum. 
Russia, Balkan States.

In Russia the close season lasts only from March 1 (13) till July 1 (13), i. e. altogether four months. Now Moscow is an important bird-market, where, especially in spring, gigantic masses of small birds are offered for sale, among others larks, titmice and quails. ${ }^{1}$ This is to some extent at variance with BACHNER's report delivered at the Vienna congress of 1873, which put the close season for capercaillys and grouse at $5 \%$ months and declared that the small birds were protected the whole year round.

There actually does exist an Imperial Society for the Prevention of Cruelty to Animals; but it is not active.

Turkey. In Turkey there is no protection for birds. On the contrary bird-catching is very much in vogue there and is practised with nets, traps and bird-lime: decoy-birds with fettered feet are also in use. This practice is mitigated by the liberation of birds, which is considered a virtue.

According to the report, at the time of the Congress, Italy, Spain, there was very little protection offered to birds in Italy, France. Spain and France. In the latter country every bird could be treated as game. As for Italy, the report quoted the figures to be found in part in the introduction to this book, which are for the most part the compilations of VALLON from Udine and Brescia statistics.

Austria. The report then turns to Austria

The conditions of this country fall into three groups. The laws of Austria concerning shooting, fishing and the protection of birds, if taken together, form a bulky volume of some 568 pages, of which 55 refer to the protection of birds specifically.

Triest. Triest, as a city belonging directly to the Empire, has no laws of its own. The other parts may be grouped as follows:

' Zoologischer Garten. Jahrg. XXIX. No. 5. 
I. Istria, Dalmatia, Sea board and Tyrol. The destruction Istria, Dalof nests and the taking of eggs is indeed forbidden, but, board, Tyin autumn and winter, bird taking is permitted by special rol. licence. Here the taking of birds is a monopoly of the parishes and its practice is regularly taxed, the tax ranging from 2 to 9 florins. The payers of this tax are called „konzessionirter Fänger“.

II. Bukovina, Görz, Gradiska, Krain, Moravia, Silesia, Bukovina, Vorarlberg, Upper Austria. The laws of the respective pro- Austria etc. vinces forbid the destruction of nests and distinguish between useful and noxious birds, which are scheduled. Bird-catching is conditional on the procuring of a licence.

III. Bohemia, Galicia, Carinthia, Salzburg, Styria, Lower The rest of Austria. The laws in force in these provinces absolutely proAustria. hibit the taking of useful birds, which are scheduled: besides, the taking of other species is also restricted.

As for Germany - i. e. of course, the whole German Germany. Empire, - the Imperial Law dated March 22, 1888 is in force: its regulations, in brief, are as follows:

The destruction of nests, the taking of eggs and broods as well as all traffic in the same is forbidden.

There is no general restriction on the taking of the eggs of birds nesting on the shores, in which are included terns, gulls and lapwings. But there may be restrictions in particular countries.

Every form of night bird-catching is prohibited.

The general close season lasts from March 1 till Sept. 15. The authorities may make exceptions in cases of special damage done.

The law does not schedule the useful birds: but there is a schedule, partly arranged in groups, of noxious birds.

The special measures of the particular countries are as follows. 
Prussia. A fine of 30 marks is inflicted on anyone who, on property not his own, takes birds not figuring as "game", who destroys nests, or takes eggs and broods.

Bavaria. A Royal Decree dated Nov. 19, 1889 protects the following birds: buntings, wagtails, tree creepers, blue breasts, red breasts, warblers, larks, finches (with the exception of sparrows and the brambling), chiff-chaffs, water warblers, titmice, woodpeckers, starlings, wheatears, storks, wrens, wrynecks etc.

Württemberg. A Royal Decree (Oct. 7, 1890) prohibits the taking of black-headed gulls' and lapwings' eggs in the neighbourhood of the Danube. The Württemberg decree protects the same birds as the Bavarian one, but excludes the white stork and the black stork, which are scheduled as noxious.

Saxony. The law here in force (July 22, 1876) exempts larks, thrushes (the thrush only temporarily) and all small singing birds from the regulations of the Game Laws: crows, wild pigeons, nutcrackers and sparrows are not protected at all.

Baden. The regulations concerning thrushes are partly at variance with those of the other countries. The fieldfare may only be shot. The law (July 13,1888) protects almost the same species as that of Bavaria.

Hessen. The law for the protection of birds is one of the older ones (April 7, 1837); it forbids the killing of birds useful to agriculture, the destruction of nests and the collection of eggs. An exception is made with sparrows and crows. The ministry may grant exemptions for scientific purposes. A remarkable law, unique of its kind, is one passed later on, which forbids the clipping of hedges between August 1 and March 1.

Alsace-Lorraine. Here the useful birds are protected: in 
contrast to the other countries, jackdaws, rooks and starlings are included among those protected all the year round.

As we have seen, in the case of the German Empire the several States take measures of their own, often quite diverse ones.

Switzerland. Here $\S 4$ of the Game Laws provides for the protection of birds. The law protects all insect-eaters, finches as well; larks, starlings and thrushes (except the fieldfare), finches and gold-finches; creepers, crows, buzzards, kestrels, owls (except the eagle owl), storks and swans. Sparrows, starlings and thrushes which frequent vineyards may be shot by the owners till after the vintage. Every kind of bird-catching is absolutely forbidden. $\S 18$ of the Law provides that the protection of birds shall be fostered and taught in the elementary schools.

Belgium. The most essential enactments of the "Règlement d'administration générale" (March 1, 1882) are as follows: sub $A$ ) we find a list of all species that, with their eggs and nests, are to be protected all the year round; $B$ ) contains a schedule of all species to be protected during the period when partridge shooting ceases (i. e. they may be shot during the partridge season); C) contains a list of all species that may be shot all the year round; among them we find the jay, the magpie and the wild pigeon. Finches may be transported all the year round, if the owner can prove by official evidence that they are his and that he is not dealing in them. The employment of little owls, bird-lime and traps is forbidden.

Holland protects all birds useful to agriculture and forestry, their eggs and nests, according to the following groupings: a) those useful at all times; b) those useful in the first 9 months of the year; c) includes insect-eaters, thrushes, larks etc.; d) includes finches and ortolans. The law does 
not touch enclosed places (preserves) or trenches. Exceptions may be made for scientific purposes.

Great Britain. The Wild Birds Protection Act (43 and 44 Vict. ch. 35: Sept. 7, 1880) prohibits the taking or killing of wild birds between March 1 and August 1 as well as the use of decoy birds or any other instrument for the taking of birds. The possession of wild birds after March 15 is forbidden. If any offence is committed against any of the 85 species $^{1}$ included in the schedule annexed to the Act, it is punishable with a fine not exceeding twenty shillings; if committed against other birds the milder enactments of the Act dated Aug. 10, 1872 are available. According to this law the offender, in the case of first offence, is reprimanded and discharged on payment of costs; for every subsequent offence he must forfeit and pay for every wild bird, in respect of which an offence is committed, a sum of money not exceeding five shillings, in addition to the costs, unless it can be proved that the bird was taken during the open season or from some person residing out of the United kingdom. This section does not apply to the owner or occupier of any land or to any person authorised by the same. This is based on a law dating from Aug. 22, 1801."

Norway. There is a close season only for the permanent birds of the country, e. g. eiders and grouse. Here and in Sweden, where there is a close season for pheasants as well as grouse, small birds are not taken in any form.

In the laws here explained in brief the leading principle is that of usefulness, though we can occasionally perceive

1 This number is not explained here, but will be below in the comparative treatment.

2 A more precise expianation of English laws and conditions will be found below. 
the effect of pity and aesthetic feeling as well as the tendency produced by education.

The writers considered that, if it were a question of framing international laws, the latter could not be made too narrow, but should give every country and every province an opportunity of taking any special measures, within the scope of the said laws, required by the peculiar conditions of the said country or province. It would be not only unfair but quite impossible to frame a law that should order everything for the states of the northern and tepid zone.

It was very practical to keep to what already existed, to the historical, in discussing international regulations. From this point of view it would be desirable to abide by the Austro-Hungaro-Italian Declaration of 1875, which, though perhaps not perfect and deficient in some respects, would in any case do much to further the cause of bird-protection if it could come into force in all the States of Europe.

The Report finally pointed out that individual combination could do much to further the cause and called upon the members of the class to use their whole influence to create societies for the protection of birds.

This Report entirely ignored the well-known sentimental point of view (i. e. sentimentalism), and for that very reason, as well as for its sober conceptions and its through dissection of the cause of bird-protection, produced an excellent impression.

Then followed IzIDOR MÁDAy's Report, one of the objects of which was to explain more precisely the Hungarian point of view and so place that country in the van of progress.

MÁDAY took as his starting-point, not the resolution of First International Ornithological Congress (1884) but that of the $26^{\text {th }}$ Great Assembly of the German Agriculturists and Foresters (1868), which was the first to recognise the economic 
importance of international birds-protection and appealed to Austria and Hungary to take the necessary steps. His introduction was, consequently, historical and followed, step for step, the thread followed by this sketch. Thus he arrived at the "Declaration" of 1875, with the accompanying protocol, and finally at the First International Congress of 1884 with its resolution: then he put the question, "quid tunc?"

He anticipated the answer by quoting figures relating to the wholesale taking of birds in vogue in Italy; and then, comparing the Vienna resolution of 1884 with the „Declaration" of 1875 , proved that the latter contained all that the former did, while in point of details it went farther still and was therefore to be abided by as a ready basis, able to materially further the cause, if only from the point of view of opportunism.

He admitted that the "Declaration" was not the ideal of bird-protection, among other reasons, because it did not contain a schedule of the species to be protected: but in his report be could afford to ignore that fact, for a schedule that should be suitable for all countries could not be drawn up, as it would only render an agreement in principle more difficult. For that reason be presented the following resolution:

„The Second International Ornithological Congress requests the Royal Hungarian Minister of Agriculture, in conjunction with the Imperial Austrian Minister of Agriculture and the Austro-Hungarian Foreign Minister, to take all steps necessary to the creation of an international convention for the protection of birds useful to agriculture.

„As a basis, the Second International Ornithological Congress recommends the fundamental principles contained in the Austro-Hungaro-Italian "Declaration" of 1875 , signed on the one part at Budapest on Nov. 5, 1875, on the other at 
Rome on Nov. 29 of the same year. As to the text of a protocol to contain the acceptance of the "Declaration", it may be stated that the form recommended by the AustroHungarian Foreign Ministry in 1876 is well adapted to securing the endorsement of the various Powers.

„The Congress further declares that it desires the prohibition of the wholesale taking of useful and "game" birds, and the introduction of stricter regulations rê the sale and „transito" traffic in the same.

„The Congress further desires that these principles should be carried into effect, on their several territories, by the States endorsing the said "Declaration"."

The last two paragraphs of the resolution were annexed as a result of the discussion that followed: this was necessary in order that the resolutions presented during the debate (particularly that of Dr. Russ) might be withdrawn.

Dr. Russ's proposal was:

1. It is an international interest that a prohibition should be in force in respect to all birds during the breeding season (the regulation of the latter to be reserved for the Parliaments of the respective countries).

2. Every kind of wholesale taking of small (useful) birds to be forbidden.

3. The sale of little (useful) birds that have been killed to be forbidden.

Several considered the "Declaration" to be too mild and demanded a more peremptory tone, a course which would not have been decorous in a body that was merely asked to give an opinion.

The President put MáDAy's proposal to the vote as against that of RUSS; that of LIEBE-WANGELIN had been withdrawn in favour of MÁDAY's. The majority voted for MÁDAY's resolution as supplemented, which was unanimously 
accepted at the closing session of the Congress on May 20, 1901.

At this closing session there figured another resolution, presented by BENEDEK TISCHER, the president of the Augsburg Ornithological Society.

This resolution declared that the lamprooms of lighthouses ought to be surrounded with nets that, without diminishing the lighting power, should put an end to the well-known calamity of birds migrating at night, which flew at the glass plates protecting the light and were crushed to death.

This resolution was referred to the PIOC. ${ }^{1}$

Herewith the Second International Congress completed its activity in the field of international bird-protection. In this cause there was, indeed, no progress shown; but, in comparison with the Vienna Congress, which merely threw the "Declaration" into the shade without offering anything better in its place, it had renewed that agreement and enabled the Hungarian Government to itself take the initiative in opening negotiations with the various countries, as it actually did.

We must remark that MÁDAY's report and resolution was the result of an action begun by the Austro-Hungarian Foreign Minister on the one part and by the Hungarian Ministries of Agriculture and Public Instruction on the other, with a view to getting the "Declaration" of 1875 confirmed by challenging afresh the opinions of experts and so enabling them to abide by it as a basis for further negotiations.

The action was begun by the Austro-Hungarian Foreign Minister at the time when the assembling of the Second International Ornithological Congress at Budapest was no longer doubtful, in a despatch (No. 1853/9. A: April 7, 1890) addressed to Count ANDREw BETHLEN, then Hungarian Minister

${ }^{2}$. Which never bothered about it.

O. H. 
of Agriculture, part of which was included in the chapter headed "developments" (v. supra). From this part of the. despatch we know that the majority of the European States made their decision concerning the "Declaration“ dependent on the attitude of Germany, which was at the time engaged in the framing of a law to be put in force in the whole Empire. This Imperial Law, as we know, was passed on March 22, 1888; consequently the Austro-Hungarian Foreign Minister concluded that those States which had made their decision dependent on the German Imperial Law, would now be ready to assume a definite attitude, especially after hearing the latest opinions of the experts.

The part of the Foreign Minister's despatch referring to this question runs as follows:

"Since then the state of affairs has materially changed, for the German Imperial Law treating of the protection of birds was sanctioned in 1888: this is certainly a moment which would justify the continuation of negotiations with Germany and the other States.

We may pretty certainly presume that we may reckon on the support of the German Empire.

We may further presume that an action started by Austria, Hungary, Germany and Italy with the object of bringing about the international protection of insect-eating birds based on principles sanctioned by the respective parliaments, would not meet with an absolutely definite refusal on the part of the other States.

In the present state of affairs I should advise Your Excellency to consider whether it would not be opportune to include the continuation of the negotiations among the agenda of the Ornithological Congress which is to meet next year (1891): if the question were treated by several experts and scholars and then discussed, great progress might be achieved. 
I beg to enclose a copy of the German Birds Protection Act".

This proposition was forwarded by the Hungarian Minister of Agriculture, in a note (No. 19,001/IV: 1890, May 9) addressed to the Hungarian Minister of Public Instruction, who was entrusted with the direct organisation of the Congress; and this was the action which secured the inclusion of the question of bird-protection in the agenda of the Congress that meet in 1891, and its discussion by Class IV that was organised for the purpose.

With this the cause of international protection, like the rock of Sisyphus, rolled back to the spot where, in 1875, Count Gyula Andrássy and Visconti Venosta had placed it and had commenced rolling it uphill.

To the history of the Second International Ornithological Congress, however, belongs, as an organic part, the supplement ${ }^{1}$ showing the position at the time in Hungary of economic ornithology, i. e. of the cause of bird-protection, the essential parts of which were as follows:

The protection of useful birds is provided for, in the first place, by the Game Laws (Act XX of 1883), of which,

$\S 9$ definitely forbids the shooting of singing birds, while

$\S 30$ enacts that "whosoever destroys the nests or steals the eggs of birds (except those of noxious birds) shall be punished with a fine ranging between one and 100 florins", and

$\S 12$ enacts that the shooting of noxious birds is permissible at all periods; starlings, however, may be shot only in vineyards or orchards.

The law dealing with the field police, which was then, in 1891, only on the table of the House, was still more

${ }^{1}$ Compiled by Izıdor Máday. 
precise in its enactments concerning the protection of useful and the hunting down of noxious birds.

Concerning the protection of useful birds $\S 24$ enacted that it should be forbidden to steal or destroy the nests, eggs or broods of birds useful to agriculture.

As useful birds should figure $a$ ) those birds of prey which feed on mice and smaller mammals, e. g. the two species of buzzards, kestrels and owls; b) of creepers, the woodpeckers, wryneck and cuckoo; c) singing birds, viz. all species of swallows, nightjars, flycatchers, shrikes, finches, titmice, larks, warblers, tree-creepers, bee-eaters, and other useful birds.

This prohibition did not, however, extend to nests found in buildings.

$\S 25$ enacts that the protection of birds shall be included as a duty in the contracts of non-domestic servants, particularly in those of keepers.

$\S 79$ enacts that any person convicted of the non-extermination of noxious animals or of destroying the nests or stealing the eggs and broods of useful birds shall be liable to a fine not exceeding 25 florins.

Then again there is no trace of shooting useful birds in Hungary. The masses do not show any inclination to exterminate useful birds; in the eyes of the masses the swallow and the lark are the welcome heralds of spring; consequently they are only too glad to tolerate swallows' nests on their houses. But though in this respect no fault can be found with the masses, there can be no doubt that, by rooting out shrubberies and undergrowth, they help indirectly to decrease the numbers of useful birds

For the future this mischief can be counterbalanced by a supply of artificial nesting-boxes.

Before passing on to treat of the further moments of the development of the cause of international bird-protection, we 
must pause for a moment to consider, as a component part of the Second International Ornithological Congress, an extract of the address ${ }^{1}$ dealing with the extermination of our birds in the South, which Baron Hans BERLEPSCH kindly placed at the disposal of the Class for bird-protection. The inclusion of the same at this point is expedient, for, unfortunately, Italy has, to this day, been the real "lapis offensionis" in the way of the accomplishment of the cause of bird-protection. Why this has been, will be explained below.

Baron BERLEPSCH, the true apostle of rational bird-protection, who can already boast of great success, journeyed through those Italian districts in which the extermination of birds is in vogue. Consequently his knowledge of the evil is first-hand. His address was perfectly objective.

$\mathrm{He}$ is convinced that, though the continual decrease in birds is partly due to the destruction of the opportunities of nesting, the main cause is the wholesale bird-taking in practice in Southern Europe.

His observations (1885-1890) extended to Switzerland, the whole of Italy, the South of France, the islands of Sicily and Corsica, Algiers and Tunis.

In Switzerland and the South of France the wholesale catching of birds with nets is, indeed, prohibited: but shooting is permitted in the autumn months, a fact that is taken incredible advantage of. At this period we meet bird-shooters at every step, comfortably practising their sport beside the road on birds perched on trees planted there and telegraph wires.

This "sport" is engaged in, not by striplings, but by grown-up men who are actually proud of their bag.

BERLEPSCH describes his meeting with a sportsman of this kind not far from Chiavenna: the latter proudly" displayed

1 Chief Report. II Scientific Part, pp. 179 seq. 
his day's bag, which consisted of 51 small birds, among which were goldfinches, linnets, titmice, red-breasts, alpine accentors, meadow pipits and tawny pipits: - he did not shoot water pipits because their flesh was considered bitter.

But however large the booty shot with guns, it is a mere trifle composed to that caught.

The master of bird-catching is the Italian, who is just. as clever in the use of the snare, bird-lime or the three-fold fowler's net.

The latter net is the most important and really consists of three nets, viz. two larger nets, which are wide-meshed and a fine close-meshed smaller net, which comes between the two larger nets. The flying bird dashes into the fine net which gives way and so forms a sack beyond the meshes of the larger net, in which the bird gets entangled. These nets are sometimes a kilometre long, their width ranging between 30 centimetres and 4 metres.

The latter are used for the "Roccolo" which is formed of living hornbeams and is thus permanent; it takes many years to grow into shape.

It is in the form of a horseshoe and in its hedge-walls there are openings like windows which are placed opposite one another in pairs, the nets being stretched accordingly.

The passing birds are enticed into the trap by blinded decoy-birds, which are deprived of sight in the most ruthless manner, with redhot wires.

The trick is that, when the passing birds approach the "Roccolo", the fowlers throw the "roccolo" over them. This instrument is a disk of platted willowtwigs, on a short handle: when raised, the birds think it to be a sparrow hawk and, darting down into the Roccolo, fall into the net.

Nearly allied to this instrument are the Pressanella and 
the Passata. These instruments may be seen in every likely spot, particularly in Upper Italy, and are of all sizes.

The largest kind, which embraces every kind of taking, is more like a colony; it may be found in the district between the Lago Maggiore and the Lago di Lugano, and covers an area of from $1-1^{1} \frac{1}{2}$ square kilometres. Besides the pavilion of the owner there are permanent lodgings for the fowlers. Beside the catching apparatuses tall, reversible poles tower towards heaven: on these, in small cages, are the blinded decoy-birds which are to entice their feathered relatives from a height.

Among the poor blinded creatures were goldfinches, linnets, greenfinches, red-breasts and finches - occasionally the rare ortolan also - accentors, sparrows and thrushes.

Although it was late autumn already, the picture was as follows: one cast of the roccolo took 100 goldfinches, then another (repeatedly) 100 thrushes, and 50-60 chaffinches; then 17 accentors and 21 willow wrens. An ordinary morning's takings were 500 birds; but in September the ordinary bag was up to 2000 - on one day no less than 800 redbreasts. If we take an average of 200 birds for the season lasting $2^{1} / 2$ months, at this one spot no less than 15,000 small birds must have lost their lives. So we can comprehend that if we take the whole of Italy the number of victims amounts to millions; and if we add that the same system is in vogue in Greece and Spain, we see that the millions must be multiplied.

Bird-catching with smaller instruments, particularly with lime-twigs, is in vogue in the whole of Italy, in Sicily, Corsica, the South of France, Algiers and Tunis. Everywhere it is Europeans who practise the custom: Arabs, namely, protect birds. These lesser systems too are destructive and claim as victims the most useful of our feathered friends, viz. red- 
breasts, coal titmice etc. Swallows are actually killed with the aid of electricity in the South of France.

The taking of quails is particularly in vogue in the South of Sicily, in Naples and on the Capri Islands. In 1887 Capri exported 50,000.

In treating of the traffic in the birds caught special mention is due to Como and Varese, where in one day redbreasts are sold, not by the hundred but by the thousand, at 75 centesimo a dozen: but when the power of the sun increases, they are actually sold at 5 centesimo a dozen to prevent them rotting, etc. etc.

The writer concluded by saying that he was present at the Resurrection Festival in Southern Italy. When the priest intoned the Gloria, the congregation let loose the small birds they had brought with them in the brilliantly lighted church, as a mark of the general feeling of joy at the blissful resurrection. The wretched little winged creatures, dazzled by the light, flew at the candles only to be burned and scorched and to perish in agony.

The conclusion to be drawn from all this is that birdtaking is, with the Italian people, a deeply-rooted passion which, through the greatest material interest, that of feeding, has wormed its way into the soul and being of the people and is, consequently, unconquerable, at least at present. This will always be a factor to be reckoned with by the Italian Government.

\section{The immediate preliminaries of the Convention.}

The resolution passed at the Second Ornithological Congress held at Budapest declared for a return to the AustroHungaro-Italian "Declaration" of 1875, the value of which was proved by the Report of BERLEPSCH: had it been put in 
force and been feasible in Italy, it would hare ineant indeed a great progress in the struggle to achieve the international protection of birds.

The above resolution was doubtless responsible for the decision of Germany, communicated by way of the Austro1892. Hungarian Foreign Ministry in May 1892, to endorse the "Declaration" of $1875,{ }^{1}$ a fact which was of great significance in view of the central position of the country; its extent, and its political and social power.

The effect was sensible in France too; and in March, 1893. 1893, the French Government sent out an invitation ${ }^{2}$ to the States of Europe to attend a conference to be held at Paris to discuss the question of the protection of birds.

The invitation was discussed in Hungary by the Ministries of Public Instruction and Agriculture: after a parley on the subject, the former referred the matter to OTTO HERMAN, the Hungarian President of the Second International Ornithological Congress, who sent in his report on May 8, 1893. In this report it is proved that the members of the PIOC are bound to abide by the "Declaration" of 1875 , and that the fundamental conditions of a fresh movement, viz. the birdschedules which must form the basis for any parliamentary legislation, were wanting. The compilation of such schedules must be insisted on, for, though the principle of bird-protection was readily accepted everywhere, it was the compilation of the schedules which had hitherto been the stumbling-block.

These points ought to be brought to the notice of the French Government.

1 For. Min. No. 20,613/11. May 23, 1892.

${ }^{2}$ For. Min. No. 9637/11. March 17, 1893. 
This was done: and we shall see that the French Government followed the advice.

The invitation gave rise to a lively exchange of notes, ${ }^{2}$ as is only natural considering the departure in part from the tendency which had aimed at the propagation of the „Declaration ${ }^{\prime}$ of 1875 . Germany and Italy as well made declarations on this point. The real state of things was that only Switzerland and France " had decidedly endorsed the "Declaration" of 1875 , in consequence of the propaganda made in 1876, in the time of Count Gyula ANDŔssy and Visconti Venosta; while Switzerland had long ago proposed an international conference without achieving any result. France seemed to all appearances to be ignoring the preliminaries and starting a new action as it were.

The circumstantial nature of diplomacy was responsible for the protraction of uncertainty until 1895, on April 15 of 1895 . which year the French Government was able to renew its invitation to meet in the following June. By this the first Paris International Conference for the discussion of birdprotection had become a "fait accompli“.4

Just before the opening of the Conference the AustroHungarian Foreign Ministry confidentially informed the Hungarian Ministry of the attitude the Italian Government intended to adopt at the Conference. ${ }^{5}$

1 Min. Pub. Instr. No. 25,439 (June 17, 1893) ; Min. Agr. No. 26,447, 16,676 and 27,144 (1893).

For. Min. No. 11,131/11 (Apr. 4, 1893); No. 18,050/11 (May 5, 1894) ; No. 44,942/11 (1894); Hung. Min. Agr. No. 77,420/VII/1 a (Dec. 24, 1894) ; For. Min. No. 53,244/11 (1895); No. 15,876/11 (Apr. 17, 1895); Hung Min. Agr. No. 20,563/VII/1 a (Apr. 26, 1895).

${ }^{3}$ v. the chapter on "Developments" (1876).

${ }^{4}$ For. Min. No 24,308/11. June 10, 1895.

${ }^{5}$ For. Min. No. 23,782/11. June 14, 1895. 
The Conference was summoned for June 25, 1895: but the Hungarian, Austrian and German Government decided that their delegates should meet, those of the first two States at Vienna, those of all three States at Berlin, before proceeding to Paris, that they might come to a mutual understanding in advance.

This mutual understanding was all the nore urgent, for, thought the Hungarian Government could enact uniform regulations for the whole of the territory of Hungary, Austria was unable to do so, seeing that many of its provinces possessed organisations differing from one another in many respects and that, in the matter of bird-protection, the several provinces possessed laws that were in many points diverse. Further, the inclinations of the peoples had to be taken into account, being as they were utterly different among the Italians of the South and the German and Slav elements of the rest of the Empire.

The position of Germany was in many points similar, some of the States having very old (Lippe-Detmold had one dating from 1777) laws and regulations still in force. It was no easy task to find a solution in Paris that should smooth over all there difficulties.

The Hungarian Ministry of Agriculture was then under Count ANDOR FESTETICS, who decided that Hungary should be represented by FRANCIS SAÁROSSY-KaPELlER, Ministerial Councillor, who naturally took part in the preliminary discussions too. His official report, ${ }^{1}$ with its supplements, forms the basis of the following description of the proceedings at Paris.

The preliminary conference held at Vienna between the Hungarian delegate and the Austrian Ministry of Agriculture

${ }^{1}$ Hung. Min Agr. No. 64,921/VII. Sept. 2, 1895. 
or rather the delegates of the same, led to a complete understanding to the effect that the resolution or international convention to be carried at Paris "should not be of a different character to that of the Hungaro-Austro-Italian Declaration of 1875 ; $i$. e. the latter should constitute the starting-point for the negotiations".

Then the Hungarian delegate started for Berlin in the company of the Austrian delegate, Dr. MAX WLADIMIR BECK - then Chief of Department in the Austrian Ministry of Agriculture, when these lines were written, now Prime Minister of Austria: the two delegates met the German representatives at the Foreign Office, Berlin, on June 9, and entered into a discussion. The German delegates were: Dr. THIEL, Geheimer Oberregierungsrat, Dr. LeHMAnN, Geheimer Botschaftsrat, and Dr. Koenig and Dr. Selenka, Professors of Zoology in the Universities of Bonn and Erlangen respectively.

The German delegates declared that they could only accept the "Declaration" of 1875 or any new convention which could be reconciled with the German Imperial Act for the protection of birds passed in 1888. In the course of the proceedings it was agreed that the „Declaration" of 1875 , which no longer answered its purpose, should be remodelled.

The following meeting was attended by the Italian delegate, who had just arrived in Berlin. This delegate, EnRICo GigloliHillyer, Professor at the Higher Scientific Institute of Florence, announced that he agreed to the modification of the „Declaration" of 1875: it must not be forgotten that, at the First International Congress held at Vienna in 1884, this same delegate, acting on the instructions of his Government, declared that he must abide by the "Declaration" and could not accept any other proposal. It is true that even the present change of attitude did not in any way restrict the liberty of action of the Italian Government. 
As resolutions in point of principle the Hungarian and Austrian delegates proposed the following three axioms:

1. The protection should be extended to all birds except those noxious to agriculture and forestry.

2. The Game Laws to decide which birds may figure as "game".

3. Wholesale taking of birds to be forbidden; the transport of the same to be restricted.

These axioms were readily endorsed by the German delegates. But the Italian delegate declared that the prohibition of wholesale bird-catching in Italy was impossible and that he had instructions not to agree to any convention which contained a stipulation of that kind.

In deference to the opinion of the German delegates it was agreed that efforts must be made to secure a form of state treaty which offered better guarantees that those contained in ministerial declarations, - this referred, of course, to the „Declaration" of 1875.

Nevertheless the meeting accepted the principle that the international convention to be framed at Paris should be endowed with the legal nature of the "Declaration" of 1875 , i. e. that it should be binding only on the governments; and the right of making a fresh statement in this sense at the Paris international conference was reserved. ${ }^{1}$

It is easily understood that this recurrence to 1875 was done to pacify the Italian delegate, for only by so doing would it be possible for a resolution accepted by Hungarians, Austrians, Germans and Italians to be presented at Paris.

The Berlin resolution consisted of 15 clauses and avoided everything that could have affected Italy. In $\S 3$, which recapitulates the methods of taking, no mention is made of the

1 Report of Francis SaÁrossy-Kapeller. 
roccolo or the pressanella; in $\S 4$, which declares for the prohibition of wholesale bird-taking, the right of special legislation of the part of the States is reserved; while there are no schedules.

The pith of the resolution was as follows:

"The introduction treats of the duty of protecting birds useful to agriculture.

$\S 1$. Proclaims the duty of protecting wild birds.

$\S 2$. Protects nests, broods, and fledglings, and forbids all traffic in the same. It makes exceptions in the case of owners or occupiers of land and any persons authorised by the same, in respect of houses and yards. Exception made in the case of the eggs of water-fowl.

$\S 3$. Forbids the use of instruments for catching birds: and prohibits the taking of birds at night, in time of snow, or beside water in time of drought, with seeds mixed with poison or narcotics, with traps, snares etc., with the Dalmatian "plocke", with the "lanciaxera" or the "paratelle".

$\S 4$. Absolutely forbids wholesale taking of birds. The Parliaments of the respective countries to legislate on their own initiative concerning the methods of taking birds, as the agricultural interest of the country may demand.

$\S 5$. Open season to be from Sept. 15 till the end of February.

$\S 6$. Regulations concerning captive birds.

$\S 7$. Provides for defence against birds found doing damage in vineyards, gardens, nurseries etc. In such cases use of guns permissible. Traffic in birds killed forbidden.

$\S 8$. Exceptions to be made for scientific purposes.

$\S 9$. Where shooting is regulated by law, the convention not to be in force in preserves etc. Where it is not regulated, the respective Parliaments shall frame laws respecting winged game. 
$\S 10$. The Parliaments of the respective countries may make exceptions $a$ ) in the case of thrushes, $b$ ) in the cases of noxious birds generally, $c$ ) in respect to birds noxious to agriculture.

The remaining clauses deal with the manner of carrying out the enactments

On arriving at Paris, the Hungarian, Austrian, German and Italian delegates were told that the French Government intended to present a ready draft to the Conference; upon which they mutually agreed to wait until this draft was presented and to take no further steps until they knew its contents.

The International Conference for the discussion of birdprotection met at Paris on June 25, 1895. The members of the same were as below: it must be remarked here that the Heads of the various States appointed expert advisers („Beiräte"), for the most part famous ornithologists, to assist the delegates in their work. Ritter VICTOR TschusI von Schmidthoffen was wired for to attend the conference as the expert adviser of Austria-Hungary. The following States, arranged in alphabetical order according to their French names, were represented as follows:

Germany (Allemagne):

Dr. THIEL, Geheimer Haupt-Regierungsrat. in the German Ministry of Agriculture.

Count D'ARCo, Botschafts-Rat, Second Secretary of the German Embassy at Paris.

Prof. Koenia, Prof. of Zoology at the Univ. of Bonn.

[Bavaria (Bavarie)]:

Prof. Selenka, Prof. of Zoology at the Univ. of Erlangen. 
Austria-Hungary (Autriche-Hongrie):

Dr. Max Wladimir Beck, Chief of Dept. in the Austrian Ministry of Agriculture.

VICTOR TSCHUSI de Schmidthoffen, expert adviser. Francis SAÁROSSY-Kapeller, Chief of Dept. in the Hung. Ministry of Agriculture.

Count Paul Eszterházy, First Secretary of the A.-H. Embassy at Paris.

Belgium (Belgique):

PROST, agricultural superintendent.

GILBERT, game overseer.

Spain (Espagne):

Marquis DE Novallas, First Sec. to the Spanish Embassy at Vienna.

Richard Moragas y Ucelay, Sec. of the Madrid Roy. Agricultural Society.

France (France):

MÉline, Deputy.

TISSERAND, State Councillor, Director of Agriculture. BROCHCHI, Prof. of the National Agricultural Institute.

Oustalet, Assistant in the Nat. Hist. Museum.

Charles Gérard, Chef de cabinet in the Min. of Agriculture.

Polrson, Chief of the Dept. of Public Safety in the Ministry of the Interior.

Hennequin, Chief of the Game Dept. of the Min. of Interior.

BlanChaRd DE FARGes, consul de la première classe in the Foreign Ministry.

SAGNiÉR, Member of the French Agricultural Society. MARCHAND, Bureau-Chef in the Ministry of Agriculture. 
Great Britain (Grande-Bretagne):

Sir Herbert Eustace Maxwell, Bart. M. P.

Howard Saunders, Member of the Zoological and Linné Society.

Francis Dundas-Harford, Second Secretary of the British Embassy at Paris.

Greece (Grèce) :

Criesis, Greek Minister at Paris.

TyPaldo, Assistant Prof. at the Univ. of Athens.

Italy (Italie):

Enrico Giglioli-Hillyér, Commandatore, Prof. of

Zoology at the Higher Institute of Florence.

Luxemburg:

Vannerus, President of the Council of State, Minister at Paris.

Monaco:

Louis MAyer, Chief of the Prince's Cabinet. Holland (Pays-Bas):

Bultman, President of the Dutch Economic Committee.

Dr. Ritzema-Bos, Prof. of the Agricultural School at Wageningen.

Portugal:

Bartholomeo Fereira, First Sec. of the Portuguese Legation,

Russia (Russie):

Kulagin, Prof. in the Agricultural Institute in Moscow. Sweden (Suède):

Baron Bonde, Member of the Second Chamber. Norway :

SVERDRUP, Equerry to the king.

Switzerland:

Dr. Victor FATIO. 
The French secretaries were SAGNier and MARCHAND who were assisted by POYARD, an Editor.

The heart of the Balkans, right up to the Danube, was unrepresented.

The Conference was opened by the then French Minister of Agriculture, Gadaut, in person, who was succeeded in the chair by MÉLINE, the active president.

The French Government did actually present a ready draft to the Conference, which consisted of 10 clauses and included three schedules of birds, the first of which contained a list of useful birds to be protected, the second that of winged game, the third that of noxious birds.

The pith of the enactments included in the draft is as follows:

$\S 1$. Mutual obligations respecting the protection by law of birds useful to agriculture.

$\S 2$. Defends nests and broods of birds contained in List I; and prohibits any traffic in the same. Forbids the use of nets, snares, bird-lime etc. But permits the extermination from time to time of over-stocks of sparrows and crows, without, however, endangering other species.

$\S 3$. Outside the close season the killing of winged game (List II) is permissible. Only guns may be used. Import of birds forbidden except in open time. Protects the nests and broods of winged game, granting exemptions only to owners, occupiers or tenants of land, who may collect and may have hatched the eggs discovered in nests found in harvest-time. The destruction of noxious birds (List III) permitted if carried out without danger to other species.

$\S 4$. Prohibitions not in force in respect to farmyards or captive birds kept in cages.

$\S 5$. Exceptions may be made for scientific purposes. 
$\S 6$. The States to communicate any measures they may take to one another.

$\S 7$. Provides for the periodical international revision of such measures.

$\S 8$. Deals with the endorsement of the States.

$\S 9$. Treats of the carrying out of the Convention.

$\S 10$. Deals with the ratification of the same.

\section{Schedule of useful birds.}

Buzzard (Buteo); Buse vulgaire.

Rough-legged Buzzard (Archibuteo); Buse pattue.

Honey Buzzard (Pernis); Buse bondrée.

*Red-footed Kestrel (Cerchneis vespertina); Faucon Kobez.

*Common Kestrel (Cerchneis tinnunculus); Faucon cresserelle.

*Naumann Kestrel (Cerchneis Naumanni); Faucon cresserine.

Snowy Ow1 (Nyctea); Harfang des neiges.

*Little Ow1, Pigmy Ow1 (Athene, Glaucidium); ChevêchesChevêchettes.

*Hawk Ow1 (Surnia); Chouettes.

*Tawny Ow1 (Syrnium); Hulottes.

*Barn Ow1 (Strix); Effraie commune.

*Shorteared Ow1, *Longeared Ow1 (Otus; Hiboux et Moyen Duc.

*Small tufted Ow1 (Scops); Scops d'Aldrovande.

*Woodpeckers, all sorts of (Picus, Dendrocopus, Dryocopus etc.); Pics, toutes espèces de.

*Wryneck (Yunx); Torcol vulgaire.

*Cuckoo (Cuculus); Coucou chanteur et glandivore.

*Common Roller (Coracias); Rollier ordinaire. 
*Bee-eater (Merops); Guèpier.

${ }^{*}$ Hcopoe (Upupa); Huppe vulgaire.

*Wall Creeper (Tichodroma); Tichodrome.

*Nuthatch (Sitta); Sitelle.

"Tree Creeper (Certhia); Grimpereau.

*Swift (Cypselus); Martinet.

*Nightjar (Caprimulgus); Engoulevent.

Rock Thrush (Monticolae); Merle de Roche.

Dipper (Cinclus); Merle d'eau.

*Nightingale (Lusciniae); Rossignol.

*Blue-throat, Blue-breast (Cyaneculae); Gorge bleue.

Calliope (Calliopae) Calliope.

*Red-starts (Ruticillae); Rouge queue.

*Furze-chats (Pratincolae); Traquets.

*Wheatears (Saxicolae); Traquets.

*True Accentors (Acsentores); Accenteurs.

*Warblers, all sorts of (Sylviae); Fauvettes.

*Aquatic Warblers (Acrocephali): Fauvettes aquatiques.

*Fantail Warbler (Cisticola); Fauvette cisticole.

*Willow Warbler (Phylloscopus); Pouillots.

*Common Tree Warbler (Hypolais); Fauvettes icterines.

*Golden-crested Wren (Regulus); Roitelets.

*Wren (Troglodytes); Troglodytes.

*Titmice, all sorts of (Parus, Orites, Panurus); Mésanges de toutes sortes.

Shrikes (Lanius); Pies-grièches.

*Flycatchers (Muscicapa); Gobe mouches.

*Swallows, all sorts of (Hirundo, Chelidon, Cotyle); Hirondelles de toutes sortes.

Waxwing (Ampelis); Jaseur de Bohême.

Oriole (Oriolus); Loriot jaune. 
*Wagtails (Motacilla, Budytes); Lavandières et Bergeronnettes.

*Pipits (Anthus); Pipits.

Sparrows (Passer); Moineaux

Bullfinch (Pyrrhula); Bouvreuils.

Oriental Bullfinch (Carpodacus); Roselins.

Pine Grosbeak (Corythus); Dur-bec ordinaire.

*Crossbills (Loxiae); Becs-croisés.

Bullfinch (Coccothraustes); Gros-bec vulgaire.

Greenfinch (Ligurinus); Verdier ordinaire.

Chaffinch (Fringilla); Pinson ordinaire.

Bramble-finch (Montifringilla); Pinson d'Ardennes.

*Goldfinch (Carduelis); Chardonneret.

*Siskin (Chrysomitris); Tarin.

*Serin (Serinus); Serin.

*Buntings (Emberiza); with the exception of the Ortolan ;

Bruants à l'exception de l'Ortolan.

*Linnets (Linariae); Linottes.

*Snow Bunting (Plectrophanes); Bruants des neiges.

*Starling (Sturnus); Étourneau.

*Rose-coloured Starling (Pastor); Martin.

Crows, all sorts of, except the Raven (Corvus); Corbeaux à l'exception du Grand Corbeau.

Pratincole (Gloreola); Glaréole.

Thickknee (Oedicnemus); Oedicnème.

Cream-coloured Courser (Cursorius); Court-vite.

Plovers (Charadrii); Pluvians.

Storks (Ciconiae); Cigogne blanche et noire.

Cranes (Grus); Grues.

Ibis (Ibis, Falcinellus); Ibis et Falcinelles.

Flamingo (Phoenicopterus); Flamant rose.

Ruff-backed Heron (Bubulcus); Garde-boeuf Ibis. 
II. Winged Game (Game Birds) birds considered as game "Oiseaux considérés comme gibier".

Blackbirds (Merula): Merles.

Thrushes (Turdus); Grives.

Larks, all sorts of (Alaudae); Alouettes de toutes sortes.

Ortolan (Ortolan, Emberiza hortulana); Ortolan.

Ring Dove (Palumbus); Pigeon ramier.

Rock Dove (C. livia); Pigeon biset.

Stock Dove (C. oenas); Pigeon colombin.

Turtle-Dove (Turtur); Tourterelle.

Sand-Grouse (Pterocles); Gangas.

Pallas Sand-Grouse (Syrrhaptes); ${ }^{1}$ Syrrhaptes.

Willow-Grouse (Lagopus); Logopèdes ou Grouses.

Tetraonides (Tetrao); Tétras ou Coqs de bruyères.

Hazel Hen (Bonasa); Gelinotte.

Francolin (Francolius); Francolin.

Partridge (Perdix); Perdrix grise.

Greek Partridge (Caccabis); Perdrix rouge.

Quail (Coturnix); Caille.

Pheasant (Phosianus); Faisan.

Bustards (Otis, Honbara); Outardes.

Plovers (Charadrius); Pluviers de toutes sortes.

Peewits, Lapwings (Vanellus, Chettusia, Hoplopterus);

Vanneaux.

Oyster-catcher (Haematopus); Huîtrier pie.

Turnstone (Strepsilas). Tourne-pierre.

Curlews (Numenii); Courli.

Godwit (Limosa); Barge.

1 This bird appears rarely in large flocks, coming from the deserts of Central Asia, and migrates to the French Coast of the Atlantic, only to disappear again. 
Woodcocks and Snipes (Scolopax, Gallinago etc.); Bécasses.

Stints (Tringae); Bécasseaux.

Sandpipers (Totani); Chevaliers et Guignettes.

Ruff (Machetes); Combattants.

Phalarope (Phalaropus); Phalaropes.

Avocet, Avoset (Avozetta); Avocettes.

Stilt (Himantopus); Echasses.

Water Rail, Land Rail, Crake (Rallus, Crex, Porzana); Râles.

Moor-Hen, Purple-Hen (Gallinula, Porphyrio); Poules d'eau et sultanes.

Coot (Fulica); Foulques.

[Wild]Swan (Cygnus); Cygne sauvage.

Wild Geese (Anseres); Oies sauvages.

Brent Goose (Bernicla); Bernaches.

Sheldrake (Chenalopex); Oies d'Égypte.

Wild Ducks (Tadorna, Anas, Chaulelasmus, Mareca, Dafila, Querquedula, Fuligula, Brenta, Clangula, Harelda, Somateria, Oidemia etc.); Canards.

Gulls (Larus); Mouettes et Goélands.

Terns (Sterna, Anous, Hydrochelidon); Hirondelles de mer.

III. Noxious Birds.

Vuitures, all kinds of (Vultur, Gyps, Otogyps, Neophron); Vautours.

*Bearded Vuiture (Gypaetos); Gypaète barbu.

*Eagles, all species of (Aquila, Nisaetus, Circaetus);

Aigles, toutes les espèces.

*Sea Eagles (Haliaetus); Pygargues, toutes espèces.

* Osprey (Pandion); Balbuzard fluviatile. 
*Kites, all species of (Milvus, Elanus, Nauclerus); Milans, toutes espèces.

*Falcons, with the exception of the Red-footed Kestrel, the Common Kestrel and the Naumann Kestrel (Falco); Faucons à l'exception des Faucons kobez, cresserelle et cresserine.

*Goshawk (Astur); Autour ordinaire.

*Sparrow-Hawk (Accipiter); Épervier.

*Harriers (Circus); Busards.

*Eagle Owl (Bubo maximus); Grand-duc vulgaire.

Kingfisher (Alcedo); Martin-pêcheur vulgaire.

*Raven (Corvus corax); Grand Corbeau.

*IMagpie (Pica); Pie voleuse.

*Common Jay (Garrulus); Geai glandivore.

*Nutcracker (Nucifraga); Casse-noix ordinaire.

*Herons (Ardea); Hérons, cendré et pourpré.

Little Herons (Ardeola); Blongois.

*Bittern (Botaurus); Butors.

*Night Heron (Nyctycorax); Bihoreaux.

Great Heron (Buphus); Héron crabier.

Spoonbill (Platalea); Spatule blanche.

*Pelican (Pelecanus); Pélicans.

Gannet (Sula); Fous.

*Cormorant (Cormoranus); Cormorans.

Frigate-bird (Fregata); Frègate.

Phaeton (Phaeton); Phaéton.

Albatross (Diomedea); Albatros.

Scouts (Procellaria, Puffinus, Thalassidroma); Pétrels, Puffins, Thalassidromes.

Bonxie (Lestris); Stercoraires.

*Smews (Mergus); Harles. 
*Grebes (Podiceps); Grèbes.

*Divers (Colymbus); Plon reons.

Razorbill (Alca); Pingouins.

Puffin (Fratercula); Macareux.

Merganser (Mergulus); Mergules.

Tystie = Black Guillemot (Uria); Guillemot.

It is evident that the draft including these three lists was meant to cover the North Polar regions and the North of Africa, an enormous stretch of land; besides, it combined protection, shooting (Game Legislation) and extermination, a vast combination.

The effect of earlier deliberations was seen in the draft contained the lists then so urgently insisted on.

From a Hungarian point of view, the list of birds to be protected might easily have been reconciled with the existing Hungarian one (§§ 57-58 of Act XII of 1894); but this was impossible in Austria where incalculable difficulties might have arisen in the various provinces. In Germany too the schedules could not have reckoned on ready acceptance on the part of the federal States.

The delegate of Italy acting on the instructions of his government, decidedly declared that Italy could not accept any proposal including a binding schedule and added that no agreement refused by Italy could be of any advantage to Hungary or Austria.

The inclusion of game legislation still further complicated the state of affairs as it affected many existing laws.

The French president, however, used every effort to have the draft discussed and accepted without delay, a course only impeded by the motion of the Hungarian delegate, which was accepted, to allow time for the study of the same.

The delegates of Hungary, Austria, Germany and Italy, 
taking advantage of this respite, met at the German Embassy, discussed the French proposal and went through that of Germany too which had been agreed upon at the preliminary conference at Berlin and, as we know, avoided including any schedules with the object of maintaining the support of Italy.

At the following plenary session the Berlin draft was read as an amendment to the French one, a fact which, however, opened up a long-winded discussion that led to no result. Finally the British delegate proposed that a sub-committee be appointed containing a representative of each State, to attempt to reconcile the two proposals.

This sub-committee, too, contained 15 members; it met, but its discussions led to no result. The dispute was all about the "Schedules"; and the question to be decided was, whether a schedule of birds should be attached to the agreement or not; if the schedule should be there, it should at least not be binding. The latter view was adopted by the Hungarian, Austrian, German, Italian, British and Dutch delegates but was opposed by the others.

THIELE's proposal for a compromise, whereby the French "schedule" principle should be defined as a desirable end in the future, could not be carried through; consequently the conference had a negative result.

Then the turn of affairs threatened the Berlin proposal, if taken before the plenum, with being out-voted: seeing this danger, the Hungarian, Austrian, German and Italian delegates determined that, if such a thing happened, they would, each independently, declare that they could take no further part in the conference and would only undertake to inform their respective governments of the results of the debates held without their assistance.

At the full assembly of the plenum held in the afternoon, 
a fresh attempt at friendly agreement having proved unsuccessful, the Italian delegate made the declaration previously formulated, a step in which he was followed by the Hungarian, German, Austrian, British and Dutch delegates.

At this critical juncture the delegate of Luxemburg stated that an agreement would be impossible if so large a proportion of the States withdrew, and proposed that a limited committee be appoint to attempt a reconciliation. This proposal was accepted and the said committee was constituted as follows: Tisserand, Tiliel, Fatio, Prost, with the Austrian and Hungarian delegates.

At the meeting of the same TISSERAND yielded on some points; and then the Berlin clauses were taken as basis, a fact which resulted in a similar compliancy on the part of the creators of the Berlin draft. Thus in a comparatively short time absolute unanimity was attained.

The draft of an agreement, with XV clauses and two schedules (useful and noxious birds) attached, was prepared. This draft was presented to the plenum of the International Conference on June 29, 1895 and was unanimously adopted. The minutes of this meeting were signed by all delegates including the representative of Italy.

According to the minutes (protocol) the delegates were to take over the draft of the agreement with the object of submitting the same to the approval of their respective governments.

Before following the further progress of the Convention, we must remark that the middle "schedule", which in the French draft dealt with winged game, was left out, for it appeared that on this point there was a great diversity of opinion between the various States, a fact that made agreement unfeasible.

It appeared, further, that expert ornithologists had, in most 
cases, absolutely opposite opinions concerning the usefulness and noxiousness of the various species: in the words of the reports "hardly had one finished his brilliant lecture proving the usefulness of one species, when another rose and just as brilliantly proved the undoubted noxiousness of the same species."

This was a clear proof of the want of biological research based on direct experience, a fact which produced results in the further development of the cause.

The epitome of the text of the draft of the convention as finally adopted is as follows:

$\S 1$. Deals with the schedules of birds voted useful or noxious, but recognises the right of signatory States to enlarge the schedules to meet the requirements of their own interests.

$\S$ 2. Protects nests, broods and fledglings, but admits the right of independent regulations concerning houses and the interior of courtyards.

$\S 3$. Prohibits instruments adapted to the wholesale taking of birds (expressis verbis: „la destruction en masse des oiseaux"), viz. nets, gins, snares, bird-lime etc.

$\S 4$. Deals with the enforcing of the foregoing clause, which may be done gradatim: but the prohibition remains in force as ultimate aim.

$\S 5$. Arranges for close season for birds to be protected, to last from March 1 to Sept. 15, except in cases provided for in $\S \S 8-9$; regulates import, transport and "transito" traffic.

$\S 6$. Defines modifications permissible by authorities.

$\S 7$. Defines exceptions to be made in the interests of science and regulates the keeping of living birds.

$\S 8$. Contains regulations relating to the poultry yard, winged game, birds living on preserves, guns and sale. 
$\S 9$. Defines the exceptions which the respective States may make.

$\S 10$. Binds the signatories to adapt their own laws to suit the Convention, within a period of three years from date.

$\S 11$. Binds the signatories to communicate to each other any laws or municipal decrees relating to the matter in question.

$\S 12$. Provides for the settling of all questions that may arise in connexion with the carrying into effect of the Convention.

$\S 13$. Deals with the eventual acceptances later on of other States.

$\S 14$. Deals with the date for the coming in force of the Convention and the conditions for withdrawal.

$\S 15$. Deals with the sanctioning of the Convention and the interchange of documents.

We have not published the full text of this draft of the Convention for the simple reason that the divergencies between the same and the text finally ratified are pointed out below.

Before passing on to relate the further history of this draft, we must give an epitome of the memorial presented by the sportsmen of France to the French Minister of Agriculture, the arguments adopted in which make it interesting and are characteristic. It occupies a position here because it owed its origin to the idea of holding the International Birds Protection Conference.

It was presented by „L Union des Sociétés de Chasseurs de France", dated Paris, June 18, 1895, signed by the Sec. JEAN ROBERT; and was annexed as a document to the archives of the "Convention".

The memorial deals with those birds of passage, which, in France, are treated as game: „les migrateurs qualifiés gibier, ou traités comme tels"! 
What the French mean thereby, we know: so in this place we need only emphasise the argument used to support the three points presented by pointing to the quail above all and, in some respects thrushes, woodcocks and larks.

It is pointed out that the quail and thrushes are to a great extent insect-eaters, a fact of great significance. In Africa (i. e. Algiers) these birds carry on a real war of extermination against the grasshoppers, which they consume wholesale. It is particularly the quail, which, since the extinction of the ostrich and the thinning of the ranks of the Houbara Bustard (Otis houbara), offers the only appreciable resistance to the "grasshopper danger" and is, therefore, of extraordinary importance to the French colonies.

The French sportsmen are sorry that the Declaration of 1875 , entered into by Germany (!), Austria and Italy, took no notice of this point. ${ }^{1}$

The French sportsmen finally presented the following three points to the approval of the International Conference:

1. Absolutely to be forbidden, on plains, in the forests or on marshes, the use of nets, snares, traps and bird-lime - filets, lacets, gluaux, trébuchets, pièges de toutes sortes in fact, every kind of bird-catching instrument except the gun, which is suitable enough (v. supra: BERLEPSCH's proposal).

2. During the close time the traffic in, the "transito" transport or colportage of birds of passage reckoned as game to be forbidden: „we Frenchmen particularly demand the prohibition of the sale and "transito" transport of quails, the example

1 The ignorance of the French sportsmen is best displayed by their writing that the Convention of 1875 was entered into in 1893 (!) by „L'Allemagne, l'Autriche et l'Italie“ : but such things, from Frenchmen, surprise us no longer. 
having been set by France, as included in the prohibitive convention."

3. An absolute prohibition to be laid on the destruction of nests, the stealing of eggs, any traffic in the same or their transport, including both those of birds figuring as game and those of small birds.

Of Points 1 and 3 we may say that they are already "public opinion": in Point 2 the "transito" transport is an important element, of great significance, not only in the case of the quail but of those of our most useful and noblest singing birds.

The noble "Association de Chasseurs" is rather mistaken in believing that all the States of Europe, apart from France, practise the taking of quails. The danger to quails hinges on two points, the wholesale taking of them in Southern Europe and in Africa and the consumption of the great Capitals of Europe. What the French chasseurs say concerning Algiers is very instructive and a warning respecting our great Hungarian plains. The Hungarian Lowlands (Alföld) have, in point of agriculture, undergone radical changes, of late quails have become very scarce, and we only occasionally come across a specimen of the once common breed of Bustard, the Little Bustard (Otis Tetrax). The draining of the country has resulted in the disappearance of the grasshoppereating gulls too. On the other hand locust-plagues are becoming more frequent: we do not mean the historical breed but the much smaller Stauronotus maroccanus, i. e. the grasshopper of Morocco; and this has become a danger. 


\section{The further progress of the Convention.}

"Re optime gesta", the delegates dispersed, each taking a copy of the draft of the Convention as accepted to his respective Government, with the minutes of the session and the appendices.

And then began the rolling of the rock of Sisyphus to the top of the hill, i. e. of course, to the top, if successful.

Those States or rather Governments which did not wish to participate, withdrew: they were Great Britain, Holland and Russia. They could do so, seeing that the fact that their delegates had signed the minutes on June 29, 1895 did not bind the States and Governments to anything, as the protocol distinctly says that the draft shall be submitted to the approval of the Governments, i. e. the final decision was reserved.

Italy lost no time in declaring ${ }^{1}$ that, for the reasons 1895 . adduced by her delegate, Prof. Gigliol, acting under instructions, first at the preliminary conference at Berlin and then at Paris, she could not accept the draft.

There is no doubt that the withdrawal of Italy was a matter of great significance, seeing that, in that country, useful birds were not only not protected but were liable, and are still liable, to the most brutal methods of wholesale destruction; and these birds were for the most part not native to Italy but merely birds of passage driven by the stress of the seasons to pass through that country, and therefore alien property as far as Italy is concerned.

This conception is not expressed here for the first time. Wild birds are, unfortunately, practically „res nullius", especially when, taking flight, they traverse zones to change their

${ }^{1}$ For. Min. No. 36,540/11. Sept. 2, 1895. 
abode: but the conception here expressed has a certain ethical, if not a legal basis, which ought to be insisted on. For the agriculture of great civilised States, which are from day to day becoming more sensible of the dearth of useful birds, this is an important matter, which demands attention from the point of view, not only of the several States concerned, but of humanity, and must not be contemplated with indifference.

The minutes of the Conference (referring to the draft of a Convention) were presented, through the Austro-Hungarian Foreign Ministry, ${ }^{1}$ to the Royal Hungarian Government, on Aug. 26, 1895: on Sept. 2. of the same year the Hungarian delegate presented his excellent report with 8 appendices. ${ }^{2}$ So, as far as Hungary was concerned, there was nothing to impede the way to the codification of the Convention, as the Government took no exception to it.

Before proceeding further, we must make a few remarks "pro domo".

On reading the certainly brilliant list of delegates, it must at once strike us that the Austrian and Hungarian delegates had one common expert adviser, whereas the two States cannot be treated as one, either politically, territorially or, in the matter of bird-protection, socially.

We must admit that in 1891 , i. e. before the Second International Ornithological Congress, there might have been some excuse for this slight: but it was out of place in 1895, since at the International Congress of 1891, Hungary displayed a galaxy of ornithologists that secured Hungary no small share of international recognition. I will go further: in

1 For Min No. 38,850/11. Aug. 26, 1895.

${ }^{2}$ Hung. Min. Agric. 64,921/VII. Sept. 2, 1895. The Report is, however, dated July $30,1895$. 
1895 the Hungarian Central Office of Ornithology was also active, consequently Hungary could have supplied an expert adviser of her own. This is not meant as a detraction from the excellent merits of Ritter von TschusI.

The progress made by the Convention henceforward was very slow, for exceptions were taken, stipulations made and hair-splitting objections to points of style, concerning all of which all the States concerned had to be approached to give an opinion before the convention could become a fait accompli.

There was, moreover, a desire expressed in some quarters for the addition of a $16^{\text {th }}$ Clause.

Of particular significance was the demand of Switzerland referring to $\S 5$ of the draft to the effect that "the protection of birds during the close season be confined to those figuring in Schedule I, i. e. that there be no reservations."

The French Government deemed the refusal of the Swiss 1899. demand to be an absolute impediment and added that without Switzerland the Convention would have no practical value. ${ }^{1}$

The Austrian Minister of Agriculture considered the Convention as a whole of trifling value and was of opinion that steps should be taken to make the French Government prevail on Switzerland to withdraw her demand. ${ }^{2}$

The Austro-Hungarian Foreign Minister informed the Hungarian Minister of Agriculture that the French Government considered the Swiss demand unacceptable and begged for the opinion of the Hungarian Minister of Agriculture, at the same time asking the latter, in case he was in favour of refusing the demand, to justify his position. ${ }^{3}$

${ }^{1}$ Hung. Min. Agric. No. 38,056/11. (No. of For. Min.), June 30, 1899.

2 Hung. Min. Agric. No. 15,368:11. (No. of For. Min.), July 5, 1899.

${ }^{3}$ For. Min. No. 38,056/11. July 7, 1899. 
In the opinion of the German Government the fulfilment of the demand of the Swiss Government would mean that the insect-eaters would not be protected at all, although they deserved to be. But, though this would be a decided weakening of the Convention, the German Government would accept it, if the Convention were not feasible otherwise; for at any rate it was or would be the first step of any moment in the cause of the international protection of birds. It would be only too glad to acquiesce if the Hungarian and the Austrian Governments, with whom it wished to go hand in hand, would do likewise. ${ }^{1}$

The Austrian Government made known that the French Government had not yet made any statement rê the Swiss alteration; but that if the refusal of the same really did involve the non-accomplishment of the Convention, the Austrian Government would accept the same on condition of being allowed to arrange the schedule for its own territory. ${ }^{2}$

This view was endorsed by the Hungarian Government too, acting on advice given by the Hungarian Central Office of Ornithology. ${ }^{3}$

The change was made.

When this serious danger had been averted and it seemed as if the States joining the movement could think of having the Convention ratified and codified, Sweden came forward, declaring that, in certain parts of the country, for the taking of certain birds, which from the point of view of bird-protection were of no consequence, the Swedish people used nets as instruments of capture, though the latter, according to $\S 3$ of the Convention, were prohibited.

${ }^{1}$ Hung. Min. Agr. 2410/eln. Sept. 22, 1899.

2 Hung. Min. Agr. 22,522/1764. Nov. 29, 1899.

${ }^{3}$ Hung. Min. Agr. 12,298/eln. Dec. 24, 1899. 
The desire of the Swedish Government was that an exception should be made in favour of this one case.

Though this fell foul of one of the chief principles of the Convention, viz. that of forbidding wholesale taking of birds, the same opportunism which had predominated during the negotiations and a desire to do something, however trifling, to further the international protection of birds, led to this request also being accepted. To this end $\S 16$ was constructed, to modify the second paragraph of $\S 8$, in which only the use of firearms is permitted. According to this alteration the employment of another method (i. e. nets) was permitted.

This was the stage in which the cause of the Convention 1900. entered the year of Grace 1900, which, as we know, the French nation was desirous of making a World's Jubilee by the holding of a World Exhibition. The brilliant occasion was utilised to arrange international worldcongresses in which every sphere of interest was concerned. In this brilliant array of international assemblies was included the Third International Ornithological Congress, which, like its Hungarian predecessors, instituted a special section for economic ornithology.

At the time of the Congress, and for some time previously, IGNÁCZ DARÁNYI was at the head of Hungarian agricultural affairs, and, interested as he was to an extraordinary extent, not only by insight but from predilection, in the cause of bird-protection, he caused the present writer to represent him at the Paris Congress, since he himself, as Hon. President of the International Agricultural Congress which was being simultaneously held, was engaged elsewhere.

The two Congresses joined hands in the cause of international bird-protection, if for no other reason, because of the predilection and enthusiasm of the President, MÉLINE 
(Chairman of the International Conference in 1895) and the Hon. President IGNáCZ Darányi. In this question each of the two statesmen influenced the other, a fact which was of inestimable advantage to the cause of international birdprotection.

The International Ornithological Congress held at Paris in 1900 is of particular significance in the history of the international protection of birds because of two events.

The first event was that the delegates of the Paris feathermerchants and of the millinery houses, - two branches which demanded and still demand the sacrifice of billions of poor birds (here I would only mention the $6,000.000,000$ hummingbirds recorded, the 400,000 pairs of lark-wings, as well as the fact that special prohibitions had to be issued to prevent the entire extinction of the birds of paradise), appeared at the Ornithological Congress to raise their voices in opposition to the cause of bird-protection which threatened to injure their material interests.

The second event implied progress in the cause of birdprotection, for the Ornithological Congress passed a resolution (with which the International Agricultural Congress identified itself) to request the respective Governments to institute thorough researches into the question of the feeding of birds to form a basis for deciding the questions of usefulness and noxiousness. This was an implicit confession that, up till 1900 , expert ornithologists had decided the question of usefulness and noxiousness rather at random, a fact which accounted for the anomaly, witnessed at the Paris International Conference of 1895 , that expert ornithologists who were asked their opinion in the matter expressed absolutely antagonistic views.

A report of the results of the researches was to have been delivered at the Fourth International Ornithological Con- 
gress held at London in 1905. But the fact is that only the Hungarian Central Office for Ornithology (an institution belonging directly under the control of the Ministry of Agriculture) gave any account of itself at London, a fact which proves that the period of 5 years was insufficient to cope with the difficulties of the question, as experts who had entered into the matter with any amount of thoroughness knew at the time.

After this digression let us return to the history of the Convention.

Owing to a dearth of data this sketch cannot pretend to cover all the side-issues of the negotiations abroad: consequently we must confine ourselves to what happened in Austria and Hungary, the Governments of which two countries continued, partly through the intervention of the AustroHungarian Foreign Minister, to actively participate in the consummation of the cause.

In 1903 the question of the Convention was a fait accompli, as far as the Hungarian Ministry of Agriculture was concerned. A memorial to the Cabinet was ready, containing the text of the Convention in the form an Act with the necessary arguments to support it. ${ }^{1}$ In the early part of this year the Hungarian Ministry of Justice sent the Ministry of 1903. Agriculture a legal report ${ }^{2}$ on the Convention and towards ${ }^{1904 .}$ the end of the same year handed in to the same Ministry its final revision ${ }^{3}$ of the text of the Convention.

But the Convention could not yet be placed on the table of the House, for it had to include Croatia as federal State, a fact which necessitated the translation of the documents

2 Hung. Min. Agr. No. 845/eln. Feb. 10, 1903.

s Hung. Min. Just. No. 38,343/I. M. II. Jan. 10, 1903.

${ }^{3}$ Hung. Min. Just. No. 42,043/I. M. II. Dec. 24, 1903. 
into Croatian, a task which, particularly in the case of the schedules, required particular attention. This was done too. ${ }^{1}$

Finally the Austro-Hungarian Foreign Minister announced that His Majesty the Emperor of Austria and Apostolic King of Hungary had, on Oct. 15, 1904, ratified the International Convention for the Protection of Birds signed at Paris on March 19, 1902."

The Hungarian Premier, on May 10, 1905, informs the Minister of Agriculture that the day for exchanging the papers relating to the International Convention has not yet been fixed. ${ }^{3}$

The Austrian Minister of Agriculture informs the Hungarian Minister of Agriculture that, according to intimation received from the Austro-Hungarian Ambassador in Paris, the ratification of the International Convention may be undertaken without delay: in the opinion of the Austro-Hungarian Foreign Minister, this step may be taken without anxiety. If there be no objection, room should be left in the protocol for Portugal and Greece too. ${ }^{4}$

The Hungarian Minister for Agriculture informs his Austrian colleague that the cause of the protection of birds is ordered in Hungary. It is regulated by Act XX of 1883 (Game Laws), Act XII of 1894 (dealing with agriculture and field police), as well as by a decree of the Hungarian Minister for Agriculture (No. 24,655/VII. 1. March 18, 1901) based on the foregoing Acts. ${ }^{5}$

1 Hung. Min. Agr. No. 9056/eln. Sept. 24, 1904.

2 For. Min. No. 76,130/11. Oct. 18, 1904.

${ }^{3}$ Hung. Pres. No. 2065. M. E. May 10, 1905.

4 Aust. Min. Agr. No. 21,487/4957. Aug. 2, 1905.

5 Hung. Min. Agr. 1090/eln. Aug. 2, 1905. (Austrian question No. $17,137 / 3991$. June 20,1905$)$. 
The said Hungarian Minister at the same time informs the Austro-Hungarian Foreign Minister that he has no objection to make to the exchange of papers nor to the leaving of room in the protocol for Portugal und Spain. ${ }^{1}$

Then the first step towards codification was taken; the discussion of the Convention in Parliament, that fell into periods of Cabinet, parliamentary and constitutional crises respectively.

The draft of the Act, with it appended motivation (dated March 23, 1904), was presented to the House by BÉLA TALlián, the successor of IGNÁCZ DARÁNYI: after having been discussed by the Economical Committee it was laid before the House on Aug. 8 of the same year. It was read a third time withont amendments and sent over to the Upper House for ratification or rather approval; there it was accepted without demur.

The Act that had been accepted by one factor of constitutional legislation was then presented to His Majesty the King for ratification.

Finally, on June 9, 1906, the Premier of the new constitutional Cabinet, Dr. Alexander Wekerle, informed the Minister of Agriculture, IGNÁCZ DARÁNYI, who had resumed his former position, that His Majesty had, as far back as Jan. 26, 1906, sanctioned the Act dealing with the codification of the International Convention for the Protection of Birds, and that, under the same date (June 9, 1906) the said Convention should be incorporated in the "Corpus Juris" of Hungary as Act I of 1906. And this was carried out in effect.

Those who had coöperated and taken pains to aid the cause had the delight of knowing that they had helped to

1 Hung. Min. Agr. 5431/eln. Sept. 18, 1905. 
incorporate the first absolutely legal document dealing with the International Protection of Birds in the "Corpus Juris" of their country, a work done in the service of humanitarianism and of inestimable value to agriculture and forestry.

The translation of the said Act dealing with the International Convention, and including the full text of the same, is as follows:

\section{ACT I OF 1906}

concerning the codification of the International Convention for the Protection of Birds useful to Agriculture signed at Paris on March 19, 1902 as well as of the two schedules forming the appendices of the same.

(Sanctioned on Jan. 26, 1906. - The papers relating to the Convention were exchanged at Paris on December 6, 1905).

\section{$\S 1$.}

The International Convention for the Protection of Birds useful to Agriculture signed at Paris on March 19, 1902 is, together with its two appendices, herewith incorporated in the laws of the country

\section{Convention}

for the protection of birds useful to agriculture.

His Majesty the Emperor of Austria, King of Bohemia etc. and Apostolic King of Hungary, in the name of His Highness Prince Liechtenstein as well; His Majesty the German Emperor, King of Prussia, in the name of the German Empire; His Majesty the King of the Belgians; His Majesty the King of Spain, and, in his name, Her Majesty the Queen-Regent of the Kingdom; the President of the French Republic; His 
Majesty the King of the Hellenes; His Royal Highness the Grand Duke of Luxemburg; His Highness the Prince of Monaco; His Majesty the King of Portugal and Algarbia; His Majesty the King of Sweden and Norway, in the name of Sweden; and the Federal Council of Switzerland, considering the adoption by the various States of an uniform procedure concerning the protection of birds useful to agriculture, have determined to make a Convention and have appointed as their respective plenipotentiaries for this purpose the following gentlemen:

On behalf of His Majesty the Emperor of Austria, King of Bohemia etc., and Apostolic King of Hungary:

His Excellency Count Wolkenstein-Trostburg, Ambassador Extraordinary and Plenipotentiary to the President of the French Republic;

O. b. of His Majesty the German.Emperor, King of Prussia:

His Serene Highness Prince Radolin, Ambassador Extraordinary and Plenipotentiary to the President of the French Republic;

O. b. of His Majesty the King of the Belgians:

Baron D'ANEThan, Minister Extraordinary and Plenipotentiary to the President of the French Republic;

O. b. of His Majesty the King of Spain and, in his name, Her Majesty the Queen-Regent of that Kingdom:

His Excellency the Marquis DE LeON Y Castillo del Muni, Ambassador Extraordinary and Plenipotentiary to the President of the French Republic;

O. b. of The President of the French Republic:

His Excellency Theophilus Delcassé, Member of the Chamber of Deputies, Foreign Minister;

O. b. of His Majesty the King of the Hellenes,

M. N. Delyannis, Minister Extraordinary and Plenipotentiary to the President of the French Republic; 
O. b. of His Royal Highness the Grand Duke of Luxemburg:

M. Vannerus, Chargé d'affaires at Paris;

O. b. of His Highness the Prince of Monaco:

M. I. P. Depelley, Chargé d'affaires at Paris;

$\mathrm{O}$. b of His Majesty the King of Portugal and Algarbia:

M. T. DE SouZA, Minister Extraordinary and Plenipotentiary to the President of the French Republic;

O. b. of His Majesty the King of Sweden and Norway, in the name of Sweden:

M. H. ÁKERMAN, Minister Extraordinary and Plenipotentiary to the President of the French Republic; and the

On behalf on Swiss Federal Council:

M. Charles LaRdy, Minister Extraordinary and Plenipotentiary to the President of the Republic of France:

The said plenipotentiaries, after an intercommunication of their powers of attorney found good and sufficient, agreed upon the following clauses:

\section{Article 1.}

Birds useful to agriculture, particularly the insect-eaters and namely those birds enumerated in the first Schedule attached to the present Convention (which Schedule the Parliaments of the several countries may enlarge by additions) shall be unconditionally protected by a prohibition forbidding them to be killed in any way whatsoever, as well as the destruction of their nests, eggs and broods.

Until such time as this result shall be completely realised, the high contracting parties bind themselves to take, or to propose to their Parliaments to take, all such measures as are necessary to carry the resolutions contained in the following clauses into effect. 
Art. 2.

It shall be forbidden, at any season and in any manner whatsoever, to steal nests and eggs, to take or destroy nestlings.

The import of these nests, eggs and nestlings, their transport, the colportage of the same, their putting up to sale, their sale and purchase shall be prohibited.

This prohibition does not concern nests built by birds in dwelling-houses, or any kinds of buildings, on the same or in the interior of court-yards, which may be destroyed by owners, occupiers or any person authorised by the same. /Further the enactments of the present Clause may be considered invalid in the case of the eggs of lapwings and gulls]. ${ }^{1}$

Art. 3.

The construction and employment of traps, cages, nets, nooses, lime-twigs or any other kind of instruments used for the purpose of rendering easy the wholesale capture or destruction of birds, shall be forbidden.

Art. 4.

In case the high contracting parties should not be in a position to enforce the prohibitions included in the preceding clause at once and in their entirety, they may mitigate the severity of the said prohibitions as required, but engage to restrict the use of methods, weapons and instruments of capture and killing in such a manner that the protective measures contained in Art. 3 may be carried into effect gradatim.

1 Later addition.

Herman: Conv. for the Prot. of Birds. 
Art. 5.

Besides the general prohibitions enacted in Art. 3, it shall be forbidden, from March 1 to Sept 15 of each year, to take or kill /those useful birds which are enumerated in the first Schedule attached to this Convention]. ${ }^{1}$

The sale or offering for sale of the same is also, during the same period, forbidden.

The high contracting parties engage, as far as their respective laws permit, to prohibit the import and delivery as well as the transport of the said birds from March 1 till Sept. 15.

/The duration of the close season prescribed in this Article may be modified in the countries of Northern Europe]. ${ }^{2}$

\section{Art. 6.}

The respective authorities may give exceptional, temporary licences to the owners of vineyards, orchards and gardens, of nurseries, afforested ground or cornfields or to the cultivators of the same or to individuals entrusted with the control of the same, for the shooting of birds whose presence is harmful and causes real damage.

However, the sale or offering for sale of birds shot under such circumstances shall be forbidden.

\section{Art. 7.}

The respective authorities may grant exemptions from the enactments of this Convention for scientific purposes or to

- Original: „les oiseaux quelconques, sauf les exceptions indiqués aux articles 8 et 9."

Modified: „les oiseaux utiles énumérés dans la liste No. 1 annexée à la Convention."

2 Additional. 
encourage the propagation of birds, in single instances and after taking all measures of precaution necessary to prevent any abuse of the same.

Permission may be granted, - similar preventive measures being taken in every case - for the taking, sale and keeping of birds intended to be kept in cages. Permission to be granted by the respective authorities.

Art. 8.

The enactments of the present convention do not apply to poultry, nor to birds regarded as game (winged game) which are on preserves and are included by the Parliaments of the respective countries among birds considered as game.

The destruction of winged game, on any other territory whatsoever, is permitted with firearms only and in the period prescribed by law.

The signatory States [are requested] ${ }^{1}$ to prohibit the sale, transport and delivery of any winged game the shooting of which is forbidden in their own country, as long as this prohibition lasts.

Art. 9.

Each of the contracting parties may grant exemption from the enactments of the present Convention,

1. In the case of birds, the shooting and destruction of which, as noxious to the interests of shooting sport and fishing, is permitted by the Parliament of the respective country;

2. In the case of birds branded as noxious to the agri-

"Originally: "s'engagent". 
culture of the country by the Parliament of the respective State.

In case there should not be an official schedule compiled by the respective legislature, $\left[\$ 2\right.$ of the present Clause] $^{1}$ shall be enforced in the case of those birds which are enumerated in Schedule 2 annexed to this Convention.

\section{Art. 10.}

The high contracting parties will take steps to have their laws brought into harmony with the enactments of the present Convention /within three years from the datel ${ }^{2}$ of the signing of the said Convention.

\section{Art. 11 .}

The high contracting parties engage to intercommunicate, through the medium of the French Government, all laws and municipal measures which are at present in force or have lately come into being regarding the subject of the present Convention.

\section{Art. 12 .}

The high contracting parties, should they find it expedient, shall have themselves represented at an international conference deputed to discuss questions that may arise in connexion with the carrying into effect of the Convention and to propose any modifications, the expediency of which has been justified by experience.

1 Originally: „l'article 9 sera appliqué".

2 Originally: „du jour fixé pour la mise en vigeur de la Convention". 
Art. 13.

Those States which have not participated in the present Convention may join the same, if they wish to do so. Any such intention must be diplomatically communicated to the Government of the French Republic and by the same to the Governments of the other signatory Powers.

\section{Art. 14}

The present Convention shall come in force at latest within a year from the date of the interchanging of papers.

It remains in force for all the signatory Powers for an indefinite period. Should any one of the same withdraw, such withdrawal does not affect the other Powers, and comes in force only one year from the day on which the withdrawal was brought to the notice of the other signatory States.

\section{Art. 15.}

The present Convention shall be ratified and the ratified documents shall be interchanged at Paris within the shortest time possible.

[Art. 16.

The enforcing of the measures contained in the second paragraph of Clause 8 of the present Convention may be dispensed with exceptionally in the Northern provinces of Sweden, owing to the absolutely peculiar climatic conditions of those regions]. ${ }^{1}$

In confirmation of which the respective plenipotentiaries 
have signed the present Convention and affixed their seals thereto.

Paris, March 19, 1902.

\section{(Signed)}

In the name of Austria and Hungary, the Ambassador of Austria-Hungary,

A. WOLKENSTEIN.

(Signed) Radolin.

(Signed) Baron d'ANETHAN.

(Signed) F. LeON y Castillo.

(Signed) Delcassé.

(Signed) N. S. Delyanni.

(Signed) VANNerus.

(Signed) I. Depelley.

(Signed) RozA DE SouzA.

(Signed) ÅKerman.

(Signed) LARDY.

\section{Schedule I.}

Us e f $u \mathbf{l}$ b ir d s.

Night birds of prey:

$$
\text { (Owls) : }
$$

Little Owl - Athene.

Pygmy Ow1 - Glaucidium.

Hawk Owls - Surnia.

Tawny Ow1 - Syrnium.

Barn Owl - Strix flammea.

Short-eared Ow1 - Brachyote.

Long-eared Ow1 - Otus.

Small tufted Owl - Scops giu, Scop. 


\section{Picariae:}

Woodpeckers, all sorts of - Picus, Gecinus etc.

\section{Syndactyles:}

Common Roller - Coracias garrula.

Bee-eater - Merops.

\section{Perching-birds :}

Hoopoe - Upupa epops.

Tree-creeper, Wall-creeper, Nuthatch - Certhia, Tichodroma, Sitta.

Swift - Cypselus.

Nightjar - Caprimulgus.

Nightingale - Luscinia.

Blue-throat - Cyanecula.

Redstart - Ruticilla.

Red-breast - Rubecula.

Furze-chat, Wheatear - Pratincola et Saxicola.

Accentor - Accentor.

All sorts of Sylvinae:

Common Warbler - Sylvia.

Lesser White-throat - Curruca.

Common Tree-Warbler - Hypolais.

Aquatic Warbler - Acrocephalus.

Great Warbler - Calamodyta.

Reed Warbler, Sedge Warbler, Grasshopper Warbler - Locustella etc.

Fantail Warbler - Cistiscola.

Willow Warbler - Phylloscopus.

Gold-crested Wren, Wren - Regulus, Troglodytes. Titmice, all sorts of - Parus, Panurus, Orites etc. Flycatcher - Muscicapa. 
Swallows, all kinds of - Hirundo, Chelidon, Cotyle. Wagtails - Motacilla, Budytes.

Pipits - Anthus, Corydala.

Crassbill - Loxia.

Bunting, Serin - Citrinella et Serinus.

Goldfinch, Siskin - Carduelis et Chrysomitris.

Starling, Rose-coloured Starling - Sturnus etPastor etc.

Waders:

White and black Storks - Ciconia.

\section{Schedule II. \\ Noxious Birds.}

Birds of prey.

Bearded Vulture - Gypaetus barbatus.

Eagles, all kinds of - Aquila, Nisaetus.

Sea Eagles, all sorts of - Haliaetus.

Osprey - Pandion haliaetus.

Kites, Blackshouldered Kites, Swallowtailed Kites, all sorts of - Milvus, Elanus, Nauclerus.

Falcons, Gyr-falcons, Peregrine Falcons, Hobby, Merlin-Stone Falcon, all sorts of, except the Redfooted Kestrel, the Common and Lesser Kestrel Falco. ${ }^{1}$

Common Goose-Hawk - Astur palumbarius.

1 The three species excepted belong therefore to Schedule I. O. H. 
Sparrow-Hawk - Accipiter.

Harriers - Circus.

\section{Owls:}

Eagle Ow1 - Bubo Maximus Flem.

\section{Perching-birds :}

Raven - Corvus corax.

Magpie - Pica rustica Scop.

Common Jay - Garrulus glandarius.

\section{Herons:}

Grey and Purple Herons - Ardea.

Bittern - Botaurus.

Night Heron - Nycticorax.

Swimming-birds:

Pelican - Pelecanus.

Cormorant - Phalacrocorax, Graculus.

Smews - Mergus.

Divers - Colymbus.

\section{$\S 2$.}

The carrying into effect of the Convention in this Act is entrusted to the Royal Hung. Minister for Agriculture and, in Croatia-Slavonia-Dalmatia, to the Banus of those countries. 


\section{Concluding words.}

If we take a look at the schedules of useful and noxious birds, we shall at once be struck by an error in the drafting: viz. the Red-footed Kestrels, Common and Lesser Kestrels are not included in Schedule I but have found their way in to Schedule II (of noxious birds) as exceptions. The same fault is to be found in the original French Text annexed to this book, - „Faucons.... à l'exception des Faucons Kobez, cresserelle et cresserine."

The Convention takes no account of the glory of the forests, the Golden Oriole, nor of any species of thrush. The discussion of this question is reserved for another place.

Yet we must admit that, if all the States of Europe should endorse the Convention, that would mean a great progress indeed: so the propaganda is entirely justified.

The chief question, one which is now, so to say, on the lips of every man, is, "What will Italy do? Is there any hope of improvement?"

To day there is none!

Nay, the state of things has deteriorated. The acceptance of the Paris Convention has invalidated the "Declaration" of 1875, the work of Count Gyula ANDRÁsSY and VisconTI VENOSTA, the only document which bound Italy to protect useful birds.

We know that the taking of birds forms an essential element of the being of the Italian people: it is connected moreover with vast material interests; and we know how difficult it is to do away with any tendency of the kind, especially where the people is inclined to give way to the temptations of games of chance and is, therefore, only too ready to engage in any work (such as bird-catching) which, in the conceptions of the world at large, requires a certain 
amount of "luck". What an enormous pressure this brings to bear even upon the most enlightened statesmen!

It is only the thought of such mighty pressure that can reconcile us to Game Laws such as those of Italy, the most important Clause (5) of which is an encouragement of the passion of bird-extermination.

When, on June 27, 1904, Luigi Rava, the Minister for Agriculture, laid the Game Laws on the table of the House, he rose to poetic heights in pleading their justification, saying:

"Nè ai nostri giorni, nei quali deve muovere la fede degli educatori la virile sentenza: "mens sana in corpore sano", sarebbe perdonabile il disconoscere la utilità dell' esercizio fisico della caccia, onde

\section{Manet sub Jove frigido}

\section{Venator, tenerae conjugis immemor}

come canta Orazio".1

But if we examine everything included in the Italian draft under the title of really invigorating, genuine hunting, we shall find, not only that the catching and wholesale butchery of snipe ${ }^{2}$ is practised just in spring when they are flocking up, and that of quails when, after passing the sea, they seek rest, half-dead with fatigue, on the beautiful coasts of Italy, but that the Permanent Committee of the Italian Senate, during the 1904-1905 Session, while discussing the said Laws proposed to draft "Articolo 5“, as far as birds are concerned, as follows:

"It shall be permitted to shoot, permanent birds from Aug. 15 till Jan. 31;

1 Camera dei deputati. Dissegno di legge presentato dal ministro di agricoltura industria e commerzio, Rava. 1902-1904. Documenti etc. No. 618.

Unfortunately it is so elsewhere too! 
birds of passage from Aug. 15 till March 31;

swimming and shore birds from Aug. 15 till April 15;

quails from Aug. 15 till May 15: but, from April 15 till May 15, only at a distance of one kilometre from the seashore and only with fire-arms."

Which means that all birds of passage are given over to their fate just in autumn and spring, the periods of passage.

"Tabelia $A$ “ annexed to the Game Laws enumerates all instruments with which, in return for a certain fee, birds may be taken: among these are the „Roccolo“, the „Pressanella“, all traps and nets, closed as well as open, removable ones as well as those fixed to a particular spot, suitable for the taking of tiny birds. In brief: „Permesso di caccia con reti aperte e copertoni, solchetti fissi o vaganti agli uccelletii".

Here the lofty words of HoRATIus are out of place; they should be replaced by the words of DANTE:

„Lasciate ogni speranza ...".

But perhaps there is some hope, for everybody would believe that the same Monarch who conceived the idea of an International Agricultural Institute, will advocate the rights of the farmers' best friends, the useful little birds.

Yet we must unfortunately admit that, at the first meeting. of the International Agricultural Institute at Rome in May-June, 1905, the Hungarian delegate, Count RoBert ZselÉNSZKY, despite the support afforded his proposal by delegates of high standing, and notwithstanding his every exertion, could not succeed in having the question of the protection of birds put on the order of the day. The President displayed wonderful ingenuity in evading the question.

Now there can be no doubt that the question of the protection of birds cannot be settled all along the line, internationally and to the advantage of the agriculture of Europe as well as in the interests of humanitarianism, without the 
cooperation of Italy. It is particularly our most valuable birds of passage which, as we know, are disappearing by tribes, their extinction being helped on more rapidly by the improvements made by factories in the enormous nets and all instruments adapted to the wholesale taking of birds, which are set up in the ordinary and unchanging route of birds of passage and so are really exterminating in their effect.

In the course of the discussions held on the International Convention a hope was expressed that its endorsement would have a beneficial effect on those States in which wholesale bird-taking is in vogue. It would be matter for infinite regret should this hope prove to be entirely unfounded. 

THE PROTECTION OF BIRDS IN HUNGARY.

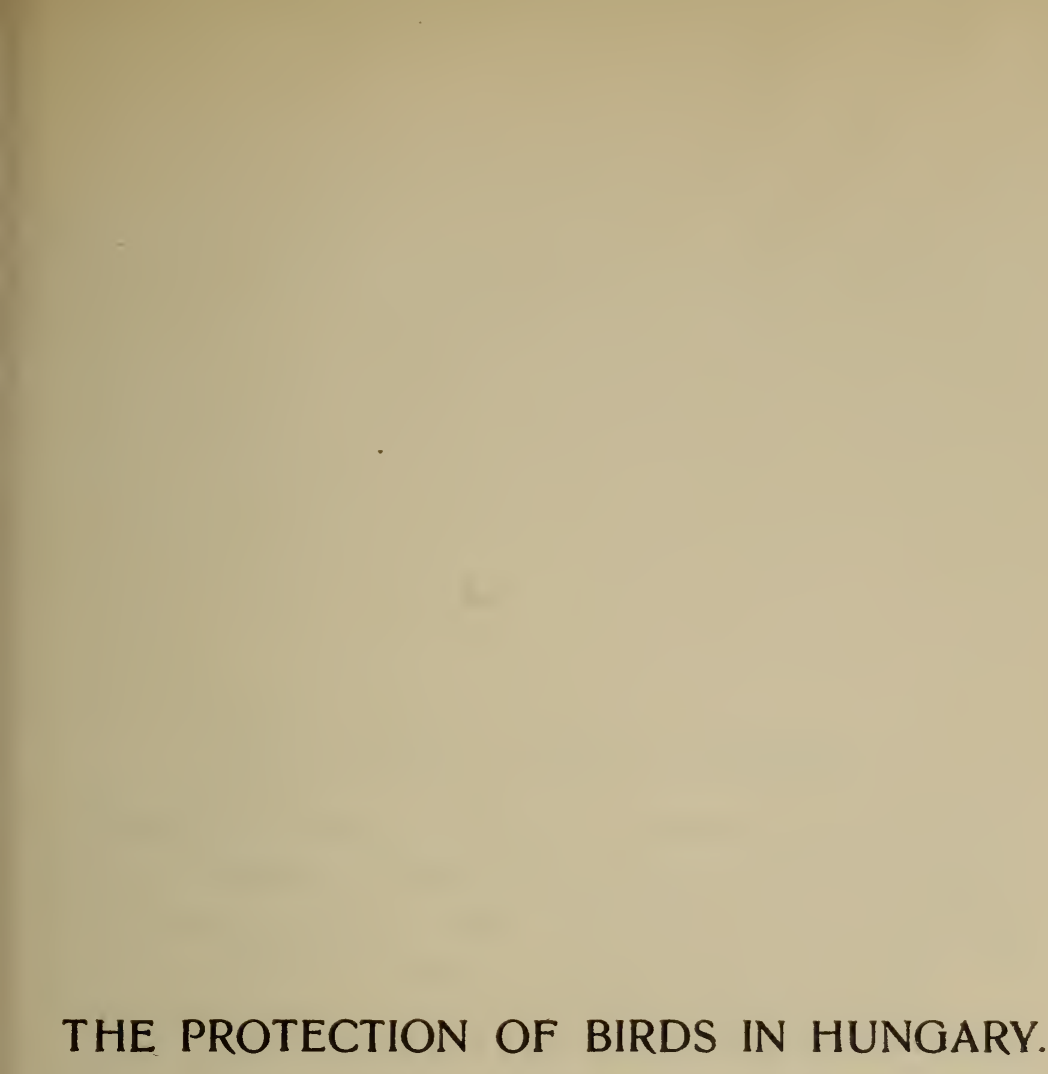





\section{The Protection of Birds in Hungary.}

The incorporation, in 1906, of the International Convention for the Protection of Birds in the "Corpus Juris" of Hungary, i. e. its being endowed with the force of law, found the rational protection of birds in Hungary a fait accompli.

As we know from what has been already stated, the protection of birds useful to agriculture is effectively enough provided by $\S \S 57-58$ of Act XII of 1894 (dealing with agriculture and field police), the carrying into effect of which is entrusted to the Royal Hungarian Ministers for Agriculture and Home Affairs.

But as is everywhere the case, it has been proved in Hungary too that the protection of birds is one of those tasks for the fulfilling of which the best-drafted Acts, though carried into effect by the authorities with the utmost severity, if done only by the State and municipal officials, is insufficient; it can only be carried into effect completely and happily by the interest and with the cooperation of the public at large.

When constitutionalism was revived, the protection of animals was revived too: but at first no particular attention was paid to birds. The first efforts were rather directed not so much towards the prevention as towards the mitigation of the cruelty to animals so prevalent everywhere. 
The Hungarian Penal Code in force, or rather those parts of it concerned with this affair, punish with a fine or retortion only those cases of cruelty to animals perpetrated publicly and in a scandalising manner: and this is not enough to check those cases of cruelty perpetrated publicly, in which the force of habit or still more indifference has seen and, in part at least, still sees nothing to scandalise.

The prevention of cruelty to animals laid the greatest stress on the protection of domestic animals, particularly dogs and horses: it could boast of undeniable successes, particularly in the Capital of Budapest, where the National S. P. C. A. was organised, and, besides that of its many enthusiastic members, gained the support of the Government and the State Police, a fact which led to splendid success.

The agitation initiated by the N. S. P. C. A. resulted in the creation of branch societies in many parts of the country; and what particularly characterised the movement was that it maintained a rational tendency. There was no drifting into the paths of the familiar "lamenting sentimentality "; and though here and there voices were raised to insist upon that tendency, common sense always won the day, such being indeed a characteristic trait of the Hungarian spirit.

The protection of birds in particular had its origin apart from the general movement for the prevention of cruelty to animals, and, in its own way, attained its present organisation and reached its culmination unaided.

As we have seen in Part I, the Second Ornithological Congress was held at Budapest, in 1891; and, as is generally admitted, the splendid preparations made for it and the excellent material discussed secured a significant success.

This success inspired Count Albin Cś́kY, then Minister for Public Instruction, with the idea of further developing this success by some permanent institution. The Minister 
consequently called upon the President of the Hungarian Scientific Committee entrusted with the organisation of the Congress, the writer of the present sketch, to prepare a suitable plan. This was how the Hungarian Central Office of 1894. Ornithology was instituted, in 1894.

This Institute had at once two tasks to perform, viz. the scientific development of the ornithology of Hungary and the thorough investigation of the phenomenon of migration. It is in the latter field particularly that, during the last ten years, the Institute has, internationally, taken a foremost place.

It is quite natural that many questions were addressed by the Government and still more by the general public to an Institute devoted solely to the development of ornithology, the institute giving an opinion and information on every point.

The decrease in the number of birds so generally felt was by many people considered to be in causal interdependence on the continual increase of insects, against which the State, roused particularly by the great blows dealt by the phylloxera plague, was already fighting with the aid of an institute, the Royal Hungarian Entomological Station.

But the discussion of the Game Laws (Act X of 1883) and the Act dealing with agriculture and field-police (Act XII of 1894) had made it clear that there was every need of works which should give the general public and farmers a true picture of birds and their life and thus acquaint them with the enormous economic significance of these pretty winged creatures. This necessity was all the more burning, as even in the civilised West, where the cause of the protection of birds had been espoused with great warmth, there was no concealing the want of objective knowledge on the part of society; and this, notwithstanding the fact that, particularly in Germany, there existed a very advanced scientific and popular literature, which, however, laid most emphasis on the natural-historical 
and sentimental side of the question and, in consequence, did not throw into relief the enormous economic interests latent in the work of birds, thus avoiding side-issues which, if only on account of their importance, might have proved of advantage even to the aesthetic point of view.

There was another question which demanded attention, viz. in the relation of the State towards bird-protection we must admit that, if the State, in the interests of the community, undertakes the protection, prohibits and punishes, the State must itself declare to what the prohibition and punishment respectively refer.

For merely to say "I defend birds useful to agriculture and forestry with prohibitions and punish him who defies the prohibition" gives rise to a whole series of questions : which birds? what are their names? what are they like? why are they useful? And if there are noxious birds too, why are they so? what are their names? what are they like? what is the damage they do? etc.

It is perfectly clear and natural that it cannot be the duty of Parliament to make the text of Acts do what the schools ought to do: but in cases where the correct application of the prohibition as well as the proper infliction of the punishment depends upon a strict definition of the objects of living Nature, the State should, even if obliged to do so outside the law itself, take steps to make everyone clearly understand what the State, by its laws, forbids or punishes. This cannot be left entirely to private enterprise, for it is not impossible that definitions and views entirely at variance with the intentions of the laws arise and involve in trouble people who have only the best intentions.

The Hungarian Central Office for Ornithology had this fact in view when it turned its attention to economic ornithology as well. The younger generation was encouraged to 
cultivate this particular branch, especially as the systematic part of ornithology, which almost entirely dropped the biological basis and devoted itself to formalism, had become very sensibly one-sided.

The creation of a work which, treating birds in the light of their agricultural significance, should satisfy expert ornithologists, give thorough information to farmers and act upon every grade of farm-labourer, was indeed a difficult task, but not an impossible one, seeing that, apart from technicalities, the highly important language question caused no particular difficulty.

The Hungarian Central Office for Ornithology was then attached to the Ministry of Public Instruction, its maintenance was secured by the Budget: so it first of all sounded its natural superior, but without success. There were doubts as to the text and the illustrations. It is undeniable that the Ministry had, in the past, had many disagreeable experiences, which obliged it to reserve in dealing with new undertakings.

The cause of the international protection of birds, however, developed, and, after the International Congress held at Budapest in 1891, followed a course which aimed at the creation, on a concrete basis, of an international convention for the protection of birds, i. e. the emphasising of general principles was given up and its place taken by a tendency which laid the chief stress on the compilation of schedules of useful and noxious birds. After half a century's work we had arrived at the point from which Baldamus in 1845 and 1856, had desired to start.

It is only natural that, after the preliminaries, a true appreciation of the cause of bird-protection could be expected only in the Agricultural Ministry of Hungary, particularly because, in the international negotiations, as we know, it was the Hungarian Ministry of Agriculture which from the very begin- 
ning, i. e. from 1868, took a direct part in the negotiations, generally as final court of appeal, - for, as is well known, in the case of international negotiations the opposition of one single party may overthrow the whole action.

Henceforward, as we know, the question of international bird-protection was always treated in organic connexion with agriculture: so, as is quite natural, the literature of the West began slowly to follow the same tendency which was made to serve the purposes of private enterprise too.

1892. As early as 1892 , a foreign firm ${ }^{1}$ applied to the Hungarian Ministry of Agriculture, offering a work published by them („Deutschlands nützliche und schädliche Vögel“) for translation.

As the Ministry had no special expert among its officials at the time, it applied to the Royal Hungarian NaturalHistorical Society for an opinion. The latter referred the matter to the present writer, who in his report, which included a thorough criticism of the work, opposed the idea of taking it over and emphatically declared for the publication of an original work for the writing of which, in his opinion, there were plenty of experts available.

But the changes in the construction of the Cabinet, which always affect tendencies, delayed the carrying out of the plan, though they did not discourage the efforts of the experts whose collaboration had been invited, who continued to make preparations.

The writer of the work had long been fixed upon in the person of Stephen Chernel de Csernelház who had not merely the expert knowledge but also, as we say, the pen to overcome the difficulties of language: while as illustrator, who could devote himself entirely to the work, the choice

${ }^{1}$ Parey, of Berlin. 
fell upon STEPHEN NÉCSEY, who, though indeed engaged particularly in the production of entomological drawings, after a comparatively short study of the subject, based on the works of the classical British illustrators, Keulemans, ThORbURN etc. and on an observation of living birds, was able to offer pictures of birds that, by the aid of skilful, softening reproductions, could hold their own with those of his masters. NÉCSEY was assisted by Gyula HÁRY, our eminent painter, whose brush knows no difficulties.

The fate of the work dealing with economic ornithology was, however, not decided till IGNÁCZ DARÁNYr took office; for among the Ministers for Agriculture of the constitutional era he was the first to bring the necessary feeling and indomitable energy to bear on the development of an agricultural literature in a manner that would make agricultural knowledge accessible to the humblest agricultural labourer.

To return to the subject of our sketch, IGNÁCZ DARÁNYI was thoroughly convinced of the great economic significance of birds, a conviction due, in his case, to his practical experience of agricultural life, and was, consequently, inclined to adopt the system of rational bird-protection. So it is quite natural that, recognising the necessity of publishing a book on economic ornithology, he used all the influence he could command to carry out the plan.

He addressed a Rescript to the Hungarian Central Office for Ornithology, entrusting the same with the carrying out of the work: and, as thorough preparations had been made for the publication (some parts of the book were already written by this time), the two volumes of the book, which was every inch of it Hungarian, were ready for publication within two years (1898-99). The full title of the work was 1898. as follows: „A földmivelésügyi magyar királyi Minister kiadványai. | Magyar Ornithologiai Központ. | Magyarország mada- 
rai | különös tekintettel | gazdasági jelentőségökre. | A földmívelésügyi magyar királyi Minister megbízásából | írta | CHERNELHÁzi ChERnEl IsTVÁN. | Képekkel ellátták Háry Gyula és NÉCSEY IstVáN, | intézte Herman OtTó | Budapest, 1898, első kötet, 1899, második kötet".1

The reproduction of the coloured illustrations was carricd out by the firm Czettel ÉS Deutsch, under the personal supervision of Gyula Czettel; and a German expert reviewer ${ }^{2}$ acknowledged that the illustrations compared favourable with those of British masters.

The Minister took care that presentation copies of the work should reach the proper quarters, a course which did much to advance its real object.

But the book could not be anything other than what it was intended for, i. e. a scientific text-book of Hungarian economic ornithology, the bulkiness of which alone was sufficient to prevent its having any direct effect on the labouring classes as a whole, who required a book of much smaller dimensions.

For this reason IGNÁCZ DARÁNYI entrusted the present writer with the compilation of a smaller work suitable for distribution among field labourers at large and adapted to the furtherance of the interest of economic ornithology and rational birdprotection.

1901. This smaller work (18 sheets in all) appeared in 1901 with the following title:

1 „Publications of the Royal Hung. Ministry of Agriculture. / Hung. Central office for Ornithology. | The Birds of Hungary | with particular regard | to their economic significance | written, | by order of the Royal Hung. Minister for Agriculture | by Stephen Chernel de chernelház |, with illustrations | by Gyula Háry and Stephen NÉCSEY published under the direction of Отто Herman / at Budapest. Vol I, 1898. Vol II, 1899.

"Reichenow, in "Ornithologische Monatsberichte", Berlin. 1899. 
„A m. kir. földmivelésügyi Minister kiadványai. | A madarak hasznáról és káráról | DARÁNYı IGNÁcz $\mid \mathrm{m}$. kir. földmívelésügyi minister megbízásából | irta | HERMAN OTTó, képekkel ellátta Csörgey Tirusz. Budapest, 1901 ". ${ }^{1}$

This little book did its best, by appealing to the feelings and taking into consideration the peculiar conceptions of the lower classes, to take hold of them, and, devoting special chapters to the more important, often very attractive features of bird-life, gradually passes over to the drier, descriptive part; here, too, only what is necessary was given, all superfluous matter was avoided and no attempt made at triviality, which is common enough in popular works; particular efforts were made to shun any tone of pedantry and sententiousness.

The little book, in its first edition, sold to the extent of 20,000 , in its second, somewhat enlarged edition, of 15,000 copies: it was published in German too.

The German translation was excellently done by JOHN Charles Rösler, Professor of the Gymnasium (Middle School) at Szászrégen: it was published by FrEDERICK EUGENE KöHLER at Gera (Reuss), with the following title: „Nutzen und Schaden der Vögel | Verfasst von | Otto Herman | Chef der st. ung. ornithologischen Centrale in Budapest. / Ins Deutsche übersetzt von | JOHANN CARL RöSLER, Gymnasial-Professor in Szászrégen. | Mit 100 Abbildungen von TITUS CsöRGEY. | Herausgegeben mit Unterstützung des königlich ungarischen Ackerbau-Ministeriums. ${ }^{2}$ | Gera-Untermhaus | 1903“.

1 „Publications of the Royal Hung. Minister of Agriculture | The Usefulness and Noxiousness of Birds | written | by order of IGnÁcz DarányI, Royal Hungarian Minister of Agriculture | by Отто Herman, illustrated by Titus Csörgey. Budapest, 1901“.

2 This referred to the fact that the Hung. Ministry of Agriculture allowed the use of the clichés free of charge. 
German criticism, based on the fact that the book contained exhaustive knowledge, acknowledged that the same was an exemplary popular book: it is given as a prize by many foreign societies. ${ }^{1}$

The expert critic pointed out that the work, with all its conciseness, was particularly rich in material and praised the splendid, life-like qualities of CsörGEV's drawings, qualities that are perhaps only natural in an artist who was at the same time an ornithologist.

It was particularly the chapter of this little book dealing with the protection of birds which attracted the attention of the German champions of the cause to Hungary, more especially as the tendency of the same was identical with that carried to victory in our days, not without a struggle, by Baron John BerlepsCh-SeEbaCH, a worthy son of the great German apiarist: of this mention is made below.

After this digression we must return to the year 1901, the culmination, through the writing and publishing of the work on the usefulness and noxiousness of birds, of an era, the moments of which connect the present with the First International Ornithological Congress, lasting for 10 years (18911901).

IGNÁCZ DARÁNYI considered the time was ripe for the taking of determined measures for the protection of animals, and particularly of birds, useful to agriculture, such measures to be given the binding force of law.

1901. Consequently on March 18,1901, after careful preparation and thorough investigations, he issued, in conjunction with the Ministers for Home Affairs and Commerce a circular decree (24655/VII. 1.), which, being founded on existing

1 Reichenow, in "Ornithologische Monatsberichte“. Berlin, 1903. 
laws, has the binding force of law, for the protection of animals useful to agriculture. It runs as follows:

Royal Hungarian Minister of Agriculture.

No. 24655.

VII. 1. 1901.

\author{
Circular Decree, \\ addressed to all local authorities.
}

On the basis of $\S \S 57$ and 58 of Act XII of 1894 (dealing with agriculture and field-police), in the interests of the protection of animals useful to agriculture, after having given due consideration to the views of the local authorities, in conjunction with the Ministers of Home Affairs and of Commerce I decree:

$\S 1$.

The following animals shall be afforded due protection:

\title{
I. Mammalia.
}

1. Bats, all kinds of, at any period.

2. Moles, except in flower and kitchen gardens and nurseries, where the may be destroyed.

3. Shrew-mice, all kinds of, except the water-shrew, which in noxious to fishing.

4. Hedgehogs.

II. Birds.

${ }^{*}$ Kestrel - Cerchneis tinnunculus. ${ }^{1}$

*Red-legged Falcon - Cerchneis vespertina.

${ }^{1}$ The birds which are asterisked $\left(^{*}\right)$ are in the schedule of the International Convention. The three species of falcon were included on the basis of the ratified Convention. 
*Naumann Kestrel - Cerchneis Naumanni.

*Short-eared Owl - Asio accipitrinus.

*Barn Owl - Strix flammea.

${ }^{*}$ Little Owl - Glaucidium noctuum.

*Pygmy Ow1 - Glaucidium passerinum.

*Tengmalm Owl - Nyctale Tengmalmi.

*Scops Ow1 - Pisorhina scops.

*Oriole - Oriolus galbula.

Rose-coloured Starling - Pastor roseus.

*Starling - Sturnus vulgaris.

* Roller - Coracias garrula.

*Hoopoe - Upupa epops.

Cuckoo - Cuculus canorus.

*Wryneck - Yunx torquilla.

Jackdaw - Corvus monedula.

*Pied Woodpecker - Dendrocopus maior.

*Middle-Spotted Woodpecker - Dendrocopus medius.

*White-backéd Woodpecker - Dendrocopus leuconotus.

*Barred Woodpecker - Dendrocopus minor.

*Three-toed Woodpecker - Picoides tridactylus.

*Great black Woodpecker - Dryocopus martius.

${ }^{*}$ Green Woodpecker - Picus viridis.

*Grey Woodpecker - Picus canus.

*Nuthatch - Sitta europaea.

*Tree Creeper - Certhia familiaris.

*Wall Creeper - Tichodroma muraria.

*Snow Finch - Fringilla nivalis.

*Chaffinch - Fringilla coelebs.

*Brambling - Fringilla montifringilla.

*Serin Finch - Serinus serinus.

*Siskin - Chrysomitris spinus. 
*Linnet - Cannabina cannabina.

*Mealy Redpoll - Cannabina linaria.

${ }^{*}$ Greenfinch - Chloris chloris.

*Goldfinch - Carduelis carduelis.

Bullfinch - Pyrrhula pyrrhula.

*Snow Bunting - Calcarius nivalis.

*Meadow Bunting - Emberiza cia.

*Yellowhammer - Emberiza citrinella.

*Ortolan - Emberiza hortulana.

${ }^{*}$ Corn Bunting - Emberiza calandra.

*Reed Bunting - Emberiza schoeniclus.

${ }^{*}$ Crested Lark - Alauda cristata.

${ }^{*}$ Wood Lark - Alauda arborea.

*Skylark - Alauda arvensis.

${ }^{*}$ White-winged Lark - Alauda sibirica.

*Shore Lark - Otocoris alpestris.

*Tree Pipit - Anthus trivialis.

*Water Pipit - Anthus spipoletta.

*Tawny Pipit - Anthus campestris

*Titlark - Anthus pratensis.

${ }^{*}$ Red-throated Pipit - Anthus cervinus.

*White Wagtail - Motacilla alba.

*Blue-headed Wagtail - Motacilla flava.

*Yellow Wagtail - Motacilla campestris.

*Black-headed Wagtail - Motacilla melanocephala.

${ }^{*}$ Grey Wagtail - Motacilla boarula.

*Great Titmouse - Parus maior.

*Coal Titmouse - Parus ater.

*Marsh Titmouse - Parus palustris.

*Sombre Titmouse - Parus lugubris. 
*Azure Titmouse - Parus cyaneus.

*Blue Titmouse - Parus coerulaeus.

*Crested Titmouse - Parus cristatus.

*Long-tailed Titmouse - Aegithalus caudatus.

* Penduline Titmouse - Remiza pendulina.

*Bearded Reedling - Panurus biarmicus.

*Golden-crested Wren - Regulus regulus.

*Fire-crested Wren -- Regulus ignicapillus.

*Wren - Troglodytes troglodytes.

${ }^{*}$ Dipper - Cinclus cinclus. ${ }^{1}$

*Hedgesparrow - Accentor modularis.

*Alpine Accentor - Accentor collaris.

*Blackcap - Sylvia atricapilla.

*Barred Warbler - Sylvia nisoria.

*Garden Warbler - Sylvia simplex.

*Orphean Warbler - Sylvia orphaea.

*Whitethroat - Sylvia sylvia.

* Lesser Whitethroat - Sylvia curruca.

*Great Reed Warbler - Acrocephalus arundinaceus.

*Marsh Warbler - Acrocephalus palustris.

*Reed Warbler - Acrocephalus streperus.

*Mustached Swamp Warbler - Calamodus melanopogon.

*Sedge Warbler - Caiamodus schoenobaenus.

*River Warbler - Calamodus aquaticus.

*Grasshopper Warbler - Locustella maevia.

*Savi's Warbler — Locustella luscinioides.

*Icterine Warbler - Hypolais hypolais. 
*Wood Wren - Phylloscopus sibilator.

*Willow Wren - Phylloscopus trochilus.

*Bonelli's Warbler - Phylloscopus bonellii.

*Chiffchaff - Phylloscopus acredula.

*Blackbird - Turdus merula.

* Mistletoe Thrush - Turdus viscivorus.

*Song Thrush - Turdus musicus.

*Redwing - Turdus iliacus.

*Ringed Ousel - Turdus torquatus.

*Rock Thrush - Monticola saxatilis.

*Blue Thrush - Monticola solitaria.

*Wheatear - Saxicola oenanthe.

*Whinchat - Pratincola rubetra.

*Stonechat - Pratincola rubicola.

*Black Redstart - Ruticilla tythis.

* Garden Redstart - Ruticilla phoenicura.

*Redbreast - Erythacus rubecula.

*Red-spotted Bluethroat - Cyanecula cyanecula.

*Nightingale - Luscinia luscinia.

*Thrush Nightingale - Luscinia philomela.

*Spotted Flycatcher - Muscicapa grisola.

*Pied Flycatcher - Muscicapa atricapilla.

*White-collared Flycatcher - Muscicapa collaris.

*Red-breasted Flycatcher - Muscicapa parva.

*Swallow - Hirundo rustica.

*House Martin - Chelidonaria urbica.

*Sand Martin Cotile riparia.

*Swift - Cypselus apus.

* Nightjar - Caprimulgus europaeus. 
*Golden Plover - Charadrius pluvialis.

*Dotterel - Charadrius morinellus.

*Kentish Plover - Charadrius alexandrinus.

*Grey Plover - Charadrius squatarola.

${ }^{*}$ Little Ringed Plover - Charadrius dubius.

${ }^{*}$ Ringed Plover - Aegialitis hiaticula.

${ }^{*}$ White Stork - Ciconia alba. ${ }^{1}$

*Black Stork - Ciconia nigra.

${ }^{*}$ Lapwing - Vanellus vanellus.

*Black-headed Gull - Larus ridibundus.

*Black Tern - Hydrochelidon nigra.

*White-winged Black Tern - Hydrochelidon leucoptera.

\section{$\S 2$.}

Any person who destroys the mammals and birds enumerated in $\S 1$, takes the birds' nests and eggs or young ones or puts them up for sale without the leave of the authorities, is guilty of an offence against $\S 95$ of Act XII of 1894 and is liable to a fine not exceeding one hundred (100) crowns (£ 4. 3. 4.).

\section{$\S 3$.}

The taking alive or killing of the animals enumerated in $\S 1$ of my present decree, the taking of the birds' nests or eggs is permitted only for scientific purposes and with the leave of the authorities.

The transport of birds' nests and eggs as well as that of the animals enumerated in $\S 1$, whether alive or dead, is permissible only with the leave of the authorities.

1 The two species of storks were included on the basis of the ratified Convention. 
$\S 4$.

Any person desirous of obtaining a licence for the capture of the animals enumerated in $\S 1$, for the taking of birds' nests or eggs or for the transport of any one of the same must produce a commission or order in writing from some Hungarian scientific institute, some expert or individual who can prove that he is engaged in natural-historical research.

Such licence may be granted by any of the first-grade authorities enumerated in $\S 102$ of Act XII of 1894.

\section{$\S 5$.}

In addition to the restrictions enumerated in $\S 4$, the authorities can grant a licence only for the capture of not more than 10 animals or the taking of not more than 10 birds' nests or eggs: this maximum to be permitted only in cases where such would not further the extinction of the said animal.

\section{$\S 6$.}

The licence for the capture of the animals enumerated in $\S 1$ or for the taking of birds' nests and eggs must be drawn up after the following pattern:

\section{Licence.}

The undersigned (authorities) grants to residing at , who has received an order from (scientific institute, school etc. name of expert engaged in physical research) an order to supply (nests, eggs, head of animals) , permission to capture or take (nests, eggs, head of animals) and keep the said animals either alive or dead in his Herman: Conv, for the Prot. of Birds. 
possession, such permission to be in force for a period of two weeks dating from today.

Dated

(signed)

(seal).

$\S 7$.

The licence to transport in any way whatsoever the animals enumerated in $\S 1$ or birds' nests and eggs is given in the following form :

\section{Transport Licence.}

The undersigned (authorities), on the basis of a legal licence from the authorities, herewith produced, for the capture of (animals, birds' eggs or nests) …..........., permit , residing at ..........., to transport the (animals, eggs or nests) above enumerated to ..... by rail, by water, by post or by hand.

Dated ..... (signed)

(seal).

$\S 8$.

The licence mentioned in $\S 6$ is avaitable for 14 days only. The transport licence, if the transport is effected by rail, by water or by post, must be taken over and retained by the forwarding agency concerned.

A licence for transport by hand or by cart can also be made available for 14 days only.

Both licences (that mentioned in $\S 7$, and that mentioned in $\S 8$ ) entitle the concessionee to capture, take or transport the number and species of animals, eggs or nests defined therein only, and may not be used more than once.

\section{$\S 9$.}

My present decree shall be published in all parishes or communities in the usual manner, the rank and file of the 
field police are to be instructed concerning its enactments and the carrying into effect of the said enactments shall be made the duty both of the forestkeepers and the surveyors of the roads.

Budapest, March 18, 1901.

(Signed)

DARÁNYI.

\section{A Comparison.}

According to the decree, which acts with the binding force of law, there are in Hungary 132 species of birds afforded protection, a number which practically contains all species of any account to agriculture in that country.

The French draft suggested about 149 species of useful birds, including such as do not exist in Hungary at all or are extremely rare (Flamingo, Cursorius, Bubulcus, some species of Ibis etc.), and included the long-eared owl as well as all species of crow exclusive of the raven.

The Convention, now figuring as Act I of 1906, in Schedule 1 containing useful species, includes approximately 103. It does not include the Little Bustard and the Bustard, which are undoubtedly useful, and play the part to which, at the International Economic Congress held at Vienna in 1873, AlfRed BREHM, in contrast to Gloger, attached so much importance (v. sub 1873) and which the French "Chasseurs" (v. sub 1895) displayed so clearly and effectively. This is of account in Hungary too, for in the Lowlands (Alföld) the damage done by insects, particularly by locusts, is on the increase, while the Bustard and Little Bustard is a continually disappearing quantity, the Quail is rarely heard of and the insectivore Gulls have been deprived of their nesting places. 
Before proceeding further with the treatment of the question in Hungary, let us take by way of comparison the condition of things in Germany.

The German Imperial Act sanctioned in 1888 (No. 1784, sanctioned on March 22, 1888) consists of 10 clauses in all, and contains, as we know from what has been already said, no schedule of species requiring protection, but contents itself with a list of those which may be considered noxious, viz. in $\S 8$ :

1. Day Birds of prey, except falcons (v. supra.)

2. Eagle Owl.

3. Shrikes.

4. Crossbills.

5. Sparrows.

6. Hawfinch.

7. Crows (Raven, Black Crow, Grey Crow, Rook, Jackdaw, Magpie, Jay, Nutcracker).

8. Wild Doves (Wood Pigeon, Wild Pigeon, Turtle Dove).

9. Moorhens (Coot etc.).

10. Herons (Night Heron, Bittern, Heron).

11. Goosanders.

12. Seagulls.

13. Cormorants.

14. Grebes.

According to this the other species of birds should be protected. But the statements of the Federal States and the towns, which were annexed to the documents supporting the Bill, are in many points at variance with the Imperial Law, as the schedule appended below will show us. These Federal States etc. are as follows: 
Aachen (1883), ${ }^{1}$ Baden (1864), Bavaria (1879), Bremen (1849), Bromberg (1883), Alsace-Lorraine (1883), Hesse (1837), Lippe-Detmold (1777), Mecklenburg-Schwerin (1879), Oldenburg (1873), Reuss-Greiz (1870), Reuss-Gera (1855), Schwarzburg-Rudolstadt (1849), Schwarzburg-Sondershausen (1860), Sachs-Altenburg (1870), Sachs-Coburg (1809), Sachs-Meiningen (1878), Saxony (1878), Sachs-Weimar (1852), Waldeck (1868), Württemberg (1878).

The schedules of all these, taken together, contain the following species:

Oriole (1) Oriolus" - Goldamsel.

Owls (6) Strix - Eule.

Hoopoe (1) Upupa - Wiedehopf.

Wagtail (3) Motacilla - Bachstelze.

Crested Lark (1) Alauda cristata - Schopflerche.

Furze-chat (2) Pratincola - Wiesenschmätzer.

Siskin (1) Chrysomitris - Zeisig.

Jackdaw (1) Corvus monedula - Dohle.

Waxwing (1) Ampelis - Seidenschwarz.

Nuthatch (1) Sitta - Spechtmeise.

Titmouse (10) Parus - Meisen.

Black-headed Gull (1) Larus ridibundus - Möve.

Buzzard (2) Buteo - Mäusebussard.

Wood Lark (1) Alauda arborea - Baumlerche.

Tree Creeper (1) Certhia - Baumläufer.

Swallows (6) Hirundo, - Schwalben.

Wrens (5) Phylloscopus etc. - Laubvögel.

Partridge (1) Perdix - Repphuhn.

1 The numbers in brackets here indicate the date of the laws and ordinances respectively of the various states and towns.

\& The numbers in brackets here indicate the number of species included in the respective genus. 
Redstart (2) Ruticilla - Rotschwänze.

Shrikes (4) Lanius - Würger.

Storks (2) Ciconia - Störche.

Curlew (1) Numenius - Sichler.

Wheatear (3) Saxicola - Steinschmätzer.

Woodpecker (8) Picus - Spechte.

Cornish Chough (1) Pyrrhocorax - Alpendohle.

Kingfisher (1) Alcedo - Eisvogel.

Cuckoo (1) Cuculus - Kukuk.

Nightjar (1) Caprimulgus - Nachtschwalbe.

Red-spotted Bluethroat (1) Cyanecula - Blaukehlchen.

Linnet (1) Cannabina - Hänfling.

Gold-crested Wren (2) Regulus - Goldhähnchen.

Flycatchers (4) Muscicapa - Fliegenschnäpper.

Plover (1) Charadrius - Regenpfeifer.

Moorhen (1) Gallinula - Moorhuhn.

Aquatic Warblers (8) Acrocephalus etc. - Rohrsänger.

Wryneck (1) Yunx - Wendehals.

Mealy Redpoll (1) Acanthis - Leinzeisig.

Wren (1) Troglodytes - Zaunkönig.

Larks (2) Alauda - Lerche.

Finches (2) Fringilla - Fink.

Pipits (5) Anthus - Pieper.

Warblers (7) Sylvia - Grasmücken.

Thrushes (8) Turdus - Drosseln.

Swift (1) Cypselus - Turmsegler.

Buntings (7) Emberiza - Ammern.

Single Snipe (1) Gallinago - Moorschnepfe.

Starling (1) Sturnus - Staar.

Bullfinch (2) Pyrrhula - Gimpel.

Jays (2) Garrulus stb. - Häher.

Roller (1) Coracias - Mandelkrähe.

Accentor (2) Accentor - Flüevögel. 
Goldfinch (1) Carduelis - Stieglitz.

Rock Dove (3) Columba stb. - Wildtauben.

Wild Duck (8) Anas - Enten.

Crow (3) Corvus - Krähen.

Hawfinch (1) Coccothraustes - Kernbeisser.

Sparrow (2) Passer - Sperling.

Rook (1) Corvus frugilegus - Saatkrähe.

Dipper (1) Cinclus - Wasseramsel.

Redbreast (1) Erithacus - Rotkehlchen.

The total of birds protected in the Federal States of Germany (the schedules begin in 1777 - Lippe-Detmold) amounts to about 152 species over against the 132 species protected in Hungary; but we must not forget that it is just the oldest schedule which defends the wild ducks and the hawfinch, while Bremen protects the sparrows, several states the shrikes, Bavaria the kingfishers and all the jays, while both buzzards and all species of crow are afforded protection. The falcons are not protected by a single one and owe their safety to the Imperial Act of 1888. So from the 150 species protected in Germany we must subtract 24 species that are unprotected; and then we shall find that Hungary protects six more such birds as deserve protection.

This will show us that IGNÁcZ DARÁNYI's intuition and energy succeeded in doing justice to all the conditions of bird-protection and made progress feasible. The actual carrying out of the same depends on the officials but more particularly on society.

And still all these facts, which excite the envy of foreign countries, do not afford complete satisfaction, for the destruction in Italy and indeed in the South generally still goes on uninterruptedly; and the number of birds is so strikingly on the decrease that Great Britain, otherwise so obstinate in clinging to her "splendid isolation", started the cry asking, 
almost in terror, what was the cause of the rapid decrease of swallows?

Great Britain's isolation is comprehensible, for the insular conditions of that country are quite different. The British Birds Protection Act, to continental conceptions, is not what it should be, but Game Laws, which hinge on the strict observance of the close time.

The Act at present in force is really an amendment of the older laws: it was passed on sept. 7, 1880, its "short title" being "The Wild Birds Protection Act, 1880".

The enactments of the said law run as follows: „§ 3 . Any person who between the first day of March and the first day of August in any year after the passing of this Act shall knowingly and wilfully shoot or attempt to shoot, or shall use any boat for the purpose of shooting or causing to be shot, any wild bird, or shall use any lime, trap, snare, net, or other instrument for the purpose of taking any wild bird, or shall expose or offer for sale, or shall have in his control or possession after the fifteenth day of March, any wild bird recently killed or taken, shall, on conviction of any such offence before any two justices of the peace in England and Wales or Ireland, or before the Sheriff in Scotland, in the case of any wild bird which is included in the schedule hereunto annexed, forfeit and pay for every such bird in respect of which an offence has been committed a sum not exceeding one pound, and, in the case of any other wild bird, shall for a first offence be reprimanded and discharged on payment of costs, and for every subsequent offence forfeit and pay for every such wild bird in respect of which an offence in committed a sum of money not exceeding five shillings, in addition to the costs, unless such person shall prove that the said wild bird was either killed or taken or bought or received during the period in which such wild 
bird could be legally killed or taken, or from some person residing out of the United Kingdom. This section shall not apply to the owner or occupier of any land, or to any person authorised by the owner or occupier of any land, killing or taking any wild bird or such land not included in the schedule hereto annexed. $\S 4$. Where any person shall be found offending against this Act, it shall be lawful for any person to require the person so offending to give his Christian name, surname, and place of above, and in case the person so offending shall, after being so required, refuse to give his real name or place of abode, or give an untrue name or place of abode, he shall be liable on being convicted of any such offence to forfeit and pay, in addition to the penalties imposed by section three, such sum of money not exceeding ten shillings sterling as to the justices or sheriff shall seem meet".

The schedule annexed to the Act is as follows:

1. American Quail - Ortyx virginianus. ${ }^{1}$

2. Auk - Alca torda.

3. Avocet - Avozetta recurvirostra.

*4. Bee-eater - Merops apiaster. ${ }^{2}$

5. Bittern - Botaurus stellaris.

6. Bonxie - Lestris catarrhactes.

7. Colin - Ortyx virginianus.

8. Cornish Chough - Pyrrhocorax graculus.

9. Coulterneb - Fratercula arctica.

10. Cuckoo - Cuculus canorus.

1 I have to thank Dr. E. H. Dresser, the eminent British ornithologist and the Tring Museum for translating the names included in the schedule into their scientific nomenclature.

2 The species marked by an asterisk are protected by the Convention. 
11. Curlew - Numenius arcuatus.

12. Diver - Colymbus.

13. Dotterel - Charadrius morinellus.

14. Dunbird - Fuligula ferina. 9 .

15. Dunlin - Tringa alpina.

16. Eiderduck - Somateria mollissima.

*17. Fern owl - Caprimulgus europaeus.

18. Fulmar - Fulmarus glacialis.

19. Gannet - Sula bassana.

*20. Goatsucker - Caprimulgus europaeus.

21. Godwit - Limosa melanura.

*22. Goldfinch - Carduelis carduelis.

23. Grebe - Podiceps.

24. Greenshank - Totanus nebularius.

25. Guillemot - Uria troile.

26. Gull - Larus (except Black-backed Gull).

*27. Hoopoe - Upupa epops.

28. Kingsfisher - Alcedo ispida.

29. Kittiwake - Rissa tridactyla.

30. Lapwing - Vanellus vanellus.

31. Lark - Alauda.

32. Loon - Colymbus septentrionalis.

33. Mallard - Anas boschas.

34. Marrot - Uria et Alca.

35. Merganser - Mergus serrator.

36. Murre - Mergulus alle.

*37. Night Hawk - Caprimulgus europaeus.

*38. Nightjar - Caprimulgus europaeus.

*39. Nightingale - Luscinia luscinia.

40. Oriole - Oriolus galbula.

41. Oxbird - Tringa alpina.

*42. Ow1 - Strix.

43. Oystercatcher -- Haematopus ostrilegus. 
44. Peewit - Vanellus vanellus.

45. Petrel - Procellariae.

46. Phalarope - Phalaropus.

47. Plover - Charadrius.

48. Ploverspage - Aegialitis.

49. Pochard - Fuligula ferina. $\sigma^{*}$.

50. Puffin - Puffinus anglorum.

51. Purre - Tringa alpina.

52. Razorbill - Alca torda.

53. Redshank - Totanus calidris.

54. Reeve or Ruff - Pavoncella pugnax.

55. Roller - Coracias garrula.

56. Sanderling - Calidris arenaria.

57. Sandpiper - Totanus.

58. Scout - Stercorarius parasiticus.

59. Sealark -... Aegialitis hiaticula.

60. Seamew - Larus.

61. Sea Parrot - Fratercula arctica.

62. Sea Swallow - Sterna.

63. Shearwater - Puffinus.

64. Sheldrake - Tadorna tadorna.

65. Shoveller - Rhincapsis clypeata.

66. Skua - Stercorarius.

67. Smew - Mergus albellus.

68. Snipe - Gallinago.

69. Solan Goose - Sula bassana.

70. Spoonbill - Platalea leucorodia.

71. Stint - Tringa minuta.

72. Stone Curlew - Oedicnemus crepitans.

*73. Stonechat - Pratincola rubicola.

74. Summersnipe - Totanus hypoleucos.

75. Tarrock - Rissa trydactyla.

76. Teal - Anas crecca. 
77. Tern - Sterna.

78. Thickknee - Oedicnemus crepitans.

79. Tystey - Uria grylle.

80. Whaup - Numenius arcuatus.

81. Whimbrel - Numenius phaeopus.

82. Widgeon - Anas penelope.

83. Wild Duck - Anates ferae.

84. Willock - Uria troile.

85. Woodcock - Scolopax rusticola.

*86. Woodpecker - Picus.

From the British schedule it is evident that the birds are protected not by species but on the basis of names in general use: that is why the Caprimulgus europaeus is protected under 4 names, viz: Tern Owl, Goatsucker, Night Hawk and Nightjar, while the Alca torda is given 2 names, viz: Auk and Razorbill, the Vanellus vanellus 2, viz: Lapwing and Peewit, the Oedicnemus crepitans 2, viz: Stone Curlew and Thickknee. The system followed is identical with that of the Hungarian "Circular Decree“.

We look in vain in this schedule for those species on the protection of which the continental states laid the greatest stress; to mention only a few; swallows and swift, bluethroat, redbreast, wheatear, accentor, warblers (of this genus only the nightingale is protected), grasshopper warbler, flycatchers, wagtails, wren, gold-crested and fire-crested wren, - all are missing from the British schedule.

On the other hand the schedule includes species which, in continental conception, are among the greatest foes of fishing: to mention only a few; the merganser, smew, diver, grebe, not to speak of the bonxie etc.

The British Act was further degraded into a mere Game Law by the fact that it did not protect nests and broods; 
but this was noticed in 1894 and, in a singular way, repaired by the "Wild-Birds Act, 1894".

The protection afforded to the broods, however, is not general and does not apply to all time. The Government is empowered, on an application by the county council, to issue an order prohibiting "the taking or destroying of wild birds eggs in any year or years in any place or places in that county". The limits of the place or places, or otherwise, the particular species of wild birds" shall be specified. The Government may "on the representation of the council of any administrative county, order that the principal Act shall apply within that county or any part or parts thereof to any species of wild birds not included in the schedule of that Act".

The protection of birds which would fulfil the requirements of continental conception, is, in Great Britain, entrusted to society and controlled by the "Royal Society for the protection of Birds".

In England „birds' " and "trees' days" are indeed in vogue: and the Royal Society for the Protection of Birds, in the customary way reward, by the presentation of shields, books and medals those who write the best essays on trees and the protection of birds.

Of late the same Royal Society has espoused the cause of artificial nesting-boxes and has erected a central warehouse near the Tower Bridge in London. ${ }^{1}$

The above comparative treatment has in any case taught us two lessons, 1. that the International Convention of 1902 offers a good basis for a uniform settlement and 2 . that the cause of bird-protection in Hungary is, for the time, in perfect order.

1 "Bird Notes and News, Circular Letter issued Quarterly by the Royal Soc. for the Protection of Birds. Vol II. No. 3."London. Sept. 1906. 


\section{The Future.}

Those who are not initiated into the secrets of the science do not remark the continual decrease of permanent nonmigrating useful birds whose work the woods and garden cannot dispense with, but they may notice the increase of worms.

Popular fancy has always considered titmice to be permanent residents: the latter are on the decrease; in fact they have entirely disappeared from places where once they existed in large quantities and did their work. Where do they go?

These too appear from time to time in the markets of the South, where they are sold by the dozen - for culinary purposes!

The next and natural question is: what drives these winged creatures to migrate, or rather to emigrate? The answer, as we know, is a very simple one, viz. that there birds nest in hollows, whereas modern forestry and gardening does not tolerate old trees, which with their hollows allured birds that lay in hollows, and so has rendered the same literally homeless: to save themselves they must wander! This point was emphasised long ago by ALFRED BREHM.

Homeless too have become our noblest song birds, most of them insect-eaters, that make their nests in bushes, for modern farming requires clear fields and so cannot tolerate the presence, here and there, of bushes and shrubs, the homes of those winged creatures which are the unpaid and faithful guardians of the crops.

All these circumstances prevailed upon Baron HANS BERLEPSCH, that truly ideal champion of the bird-world, to set down as the line to be followed what may be expressed in a short sentence: "Keep what we can".

And he has come to the conclusion that we must restore to useful birds all that the modern system has deprived them of. But as the progress of economy precludes a return to a 
primitive state of things, we must artificially restore what has been taken away.

This conviction led Baron BERLEPSCH to make a study of natural nesting-hollows and to construct a machine for tie hollowing out of artificial nesting-boxes; it led him, moreover, to the cultivation of bushes, by cutting and partly also by grafting, which should tempt birds looking for suitable nestingplaces to settle there. Of his success living examples may be send in the town-park of Cassel and the estate at Seebach, which Baron BERLEPSCH has converted into a real nesting colony.

The most surprising success attained was when, after artificial nesting-boxes fixed on stakes had been placed on the colonies on the sand-hils of North Germany, not less than $90 \%$ of the same became inhabited, within the first year, by titmice up till that time unknown in the district.

This attracted the attention of Ignácz DARÁNYı too.

Supported by the Hungarian Ministry of Commerce the first Hungarian Factory for the production of nesting-boxes has already been started, and there has appeared, from the pen of Titus CsöraEy, published by the H. O. C., a compendium of instructions dealing with the treatment and the use of nesting-boxes as well as with nesting bushes.

On June 12, 1906 the Minister (No. 3686) ordered the Hungarian Central Office for Ornithology to present a scheme for the supplying of artificial nesting-boxes to the State forests (5 million acres). This work is now in hand.

At the same period Count Albert Apponyi published his decree providing for the inclusion of birds' and trees' days in the scheme of work of elementary schools.

Thus ends the history, for the present, of the International Convention of the protection of birds. 



\section{SYNOPSIS OF EVENTS LEADING UP TO THE}

INTERNATIONAL CONVENTION

\section{FOR THE PROTECTION OF BIRDS.}





\section{Synopsis of events leading up to the International Convention.}

1845. Baldamus, at the first German Ornithological Assembly held at Köthen suggests the idea of protecting useful animals, particularly birds. Rejected.

1846. Baldamus renews his suggestion at the meeting of the Saxon Agricultural Societies. Shelved.

1856. Baldamus repeats his proposal at the second great assembly of German ornithologists, suggesting a schedule of useful birds. Ignored.

1868. The Twenty-sixth great assembly of German agriculturists and foresters held at Vienna hits upon the idea of international protection of birds, and requests the AustroHungarian Foreign Minister to take measures to secure the formation of international treaties and agreements. The first states to join are Switzerland and Italy.

1869. France approves of the scheme but attaches importance to the cooperation of Switzerland, Italy and Spain.

1871. The governments of Austria and Hungary agree to adopt the form of an agreement.

1872. Switzerland proposes the summoning of an international assembly. The Austrian Government deputes Ritter von Frauenfeld to treat with Targioni-Tosetti at Florence: 
the delegates settle 6 points, which are modified at Vienna and them presented to the Italian Government. 1873. The International Economic and Forestry Congress held at Vienna treats exhaustively of the international protection of birds. Its resolutions:

1. Agreement (Convention); points I-IX.

Schedules of birds to be protected and those to be hunted down.

Prohibitions.

International Committee. (Tschudi.)

2. Agreement (Convention), points I-III. Schedules, $A$ ) useful, $B$ ) noxious birds. (Marenzeller.)

3. The cause of the decrease in numbers of birds is modern agriculture: by overcrowding of products their enemies are increased.

It is not the taking of birds, but the destruction of nesting that is responsible for the decrease in birds. Bushes and shrubs must be replaced; hedges must be grown.

Handbooks to be distributed gratis. (A. Brehm.)

4. An international convention to be drawn up. (Settegast.)

5. Compromise; accepts the appointment of an international committee and settles points I--VII. of the basis of the Convention.

1874. The Hungarian Ministry of Agriculture accept the Vienna points as a basis for negotiations and considers them good.

1875. Count Gyula Andrássy and Visconti-Venosta sign the Austro-Hungaro-Italian „Declaration“ and decide upon the text of the protocol of acceptance. The Declaration consists of 9 clauses and does away with the most powerful Italian instruments, the Roccolo, the Pressanella and the Passata The Protocol contains 3 points. 
1876. The Austro-Hungarian Foreign Ministry commences an action in favour of the "Declaration", on the basis of the Protocol.

The majority of the states find difficulties in the way of carrying the project through.

Switzerland and France definitely join the movement. Most of the countries, however, decide to wait until the passing of the German Imperial Bill.

1884. First International Ornithological Congress at Vienna, under the patronage of the Crown Prince Rudolf. Very exhaustive treatment of the question of the international protection of birds.

1. The aesthetic interest is placed side by side with the economic one, to which it is to be subsidiary only when the latter is vital.

All birds to be protected, exceptis excipiendis. (Altum.)

2. A set of prohibitory statutes to be arranged.(Fatio.)

3. Convention urged; some conditions suggested. (Borggreve.)

4. The representative of the Italian Government declares that he must abide by the "Declaration" of 1875 .

5. The decision of the Congress is a compromise, the 2 points of which are far behind that of 1873 .

6. A Permanent International Ornithological Committee (PIOC) organised, entrusted with the creation of a network of observatories and the preliminaries of the following Congress.

7. Budapest chosen as the scene of the Second International Ornithological Conrgess.

1887. The organisation of the Second Congress taken over by the Hungarian Ministry of Public Instruction: date fixed, 1888. Bitter conflict between the Pres. and Sec. 
of the PIOC, which impedes any progress. 1889 fixed as the date for the Congress.

1889. The Crown Prince Rudolf asked to give an opinion: shortly after, his death. Later on, the revival of the idea of a Congress : negotiations.

1890. The Hungarians take into their own hands and carry through the organisation. Date finally decided on: Whitsuntide, 1891.

Meeting of Hungarian Ornithologists.

Final scheme of Congress.

Invitations sent out.

Organisation of Classes, among others that for „Economic Ornithology".

Speakers called upon: for bird-protection, Th. Liebe, Jacoby v. Wangelin and Izidor Máday.

1891. Second International Ornithological Congress at Budapest. Formation of an economic class, with Major Alexander Homeyer (Greifswald) as Chairman.

The German and Austrian proposals withdrawn in favour of that of Máday, which proposed a return to and the propagation of the Hungaro-Austro-Italian „Declaration" of 1875.

A synopsis of the treatment of the question of birdprotection in Hungary attached.

Baron Berlepsch delivers an address on the extermination of birds.

1892. Germany endorses the Declaration of 1875 .

1893. France invites all the States of Europe to attend a conference to be held at Paris to discuss the question of international bird-protection.

Beginning of negotiations.

1895. France repeats the invitation. The States accept it and appoint delegates. 
Preliminary meeting at Vienna of the Hungarian and Austrian delegates.

Preliminary meeting at Berlin of the German, Hungarian, Austrian and Italian delegates.

International assembly opens on June 25 .

French draft ready with schedules of useful and noxious birds.

Italy declares unwillingness to accept any proposals including schedules.

Compromise (§§ 1-9), with schedules of useful and noxious birds.

Draft of convention accepted.

1899. Switzerland's post facto condition rê $\S 5$. of the convention.

Sweden's post facto demand rê $\S 3$ of the convention.

1900. Third International Ornithological Congress at Paris. A study of the food of birds decided upon; reports to be sent in by 1905, at London.

1902. The International Convention for the protection of birds signed by the delegates of the signatory powers.

1903. The Convention made ready for presentation to the Hungarian Parliament.

1904. The Convention placed on the table of the Hungarian Parliament.

1906. The Convention sanctioned by Royal consent on Jan. 26; incorporated in the Corpus Juris of Hungary on Jun. 9.

The history of the protection of birds in Hungary.

1883. The Game Laws ( $\S \S 9,12,15,20$ and 30 of Act XX) regulate the condition of birds.

1894. §§ 57-58 of Act XII (dealing with agriculture and field police) settles the protection of birds. 
1901. Decree (March. 18: No. 24.655/VII. 1.) in which the Minister of Agriculture, acting in conjunction with the Ministers for Home Affairs and for Commerce, orders the protection by law of 189 species of useful birds.

1906. Ignácz Darányi, Royal Hung. Minister of Agriculture, orders the state forests to be supplied with artificial nesting-boxes (1906. July, 17 : No. 55.326/I-A. 1.). The same Minister also decrees that measures be taken that the artificial nesting-boxes be supplied by Hungarian industry.

It consequence of salutary measures taken by the Hungarian Minister of Commerce, the first Hungarian Artificial Nestingbox Factory (as department of Kühnel's Saw Mills) begins activity at Baranya-Kárász.

In consequence of measures taken by His Excellency Ignácz Darányi, and with the permission of H. I. R. H. the Archduke Joseph, a nesting and bird-feeding settlement is established on the Sct. Margaret Island. (Budapest).

In connection with the above an enquête was held, under the personal guidance of the Minister, to fix points for experiments with the artificial nesting boxes and to decide upon the means of control (Dec. 1906). An important event in this year was the decree of the Minister of Public Instruction providing for the introduction of "Birds' and Trees' Days" into the elementary schools.

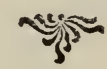


INDEX OF NAMES OF PERSONS OCCURRING IN THIS BOOK. 

Index of names of persons occurring in this book.

This index does not profess to a biographical value. Its object is merely to show, as far as possible, the position or sphere of action of those men who have worked in the interests of the international protection of birds.

Explanation of signs:

* = signed the Paris Convention of 1902.

$\Delta=$ took part in the conference at Paris in 1895 .

$t=$ deceased.

†His Imp. and R. H. the Crownprince RUDOLF.

His Imp. and R. H. the Archduke JOSEPH.

*ÅkERMAN, H., Minister Extraordinary of Sweden and Norway at Paris.

†Altum, Dr. Bernhard, celebrated Professor of the Academy of Forestry at Eberswalde.

†ANDRÁssY, Count GYuLA, sen., world-famed Hungarian statesman. Cooperated with Francis Deák, Prince Bismarck, Lord Beaconsfield and other celebrated contemporaries.

*D'ANETHAN, Baron, signed the Paris Convention. Belgian Ambassador, Paris.

APPONYI, Count ALBERT, Hungarian Minister for Public Instruction, famous orator and statesman.

$\triangle_{\mathrm{D}}$ 'ARCO, Count, Councillor to the German Embassy in Paris, 1895. 
BACHNER, ADOLF, champion of the prevention of cruelty to animals in Russian Poland, Warsaw.

+BAldamus, Dr. EDWARD, Pastor oy the Evangelical Church, famous ornithologist, Coburg.

†BÁTHORY, NÁNDOR (FERDINAND), Director of a Realschool (Modern School), Budapest.

$\triangle$ BECK, Dr. MaX Wladimir, Austrian Prime Minister, Vienna. At the time of the Conference at Paris (1895) was chief of department in the Austrian Ministry of Agriculture.

BERG, Baron H., Forester in 1891, Strassburg.

BERLEPSCH, Baron HANS, son of the great apiarist, founder of the system of rational bird-protection, Cassel.

Berzeviczy, Dr. AlBerT de, Secr. of State in 1891, later Minister of Public Instruction, Budapest.

†BETHLEN, Count ANDREw, Hungarian Minister of Agriculture.

BIKKESY, GUIDO, private gentleman, Magyar-Óvár.

BISHOP, Dr. LEWIS, ornithologist, New-York.

$\triangle$ BLANCHARD DE FARGES, consul de la première classe, Paris.

BlasiUS, Dr. RUDOLF, Professor, famous German ornithologist, Brunswick.

Blasius, Dr. William, Professor, prominent German ornithologist, Brunswick.

BLOMEYER, champion of the protection of animals, Leipsic.

BorTEL, M., Superintendent in the French Ministry of Agriculture, Paris.

$\triangle$ BONDE, Baron, member of the Swedish second chamber, Stockholm.

Borgareve, Dr. B., Professor of the Academy of Forestry at Münden.

BOSSI-FEDRIGOTTI, Rovereto.

+BREHM, Dr. AlFRED, world-famed German animal-biologist, Berlin.

$\triangle \mathrm{BROCCHI}$, Professor of the National Agricultural Institute, Paris.

BüCHNeR, Eugene, Russian Zoologist, St. Petersburg.

$\triangle$ BultmanN, President of the Dutch Agricultural Committee.

BÜTTIKOFER, JOHN, Dutch Zoologist, Leyden (later Rotterdam).

CAstıllo, LeON Y, Marquis del Muni, Minister Extraordinary of Spain, Paris. 
Chadbourne, Dr. ARThur, Ornithologist, New-York.

Chernel, Stephen de Chernelháza, Eminent Hungarian Ornithologist, writer of the Hungarian work on Economic Ornithology, Kőszeg.

Chlumetzky, Baron JoHN, prominent Austrian politician, later Minister, Vienna.

+Claus, Dr. Charles, Professor, eminent Zoologist, Vienna.

COllet, ROBERT, eminent Norwegian ornithologist, Christiania.

†CORdeaux, John, eminent English urnithologist, Great Cotes.

$\triangle$ CRIESIS, Greek Legate at Paris in 1895.

Csáky, Count AlBIN, formerly Hungarian Minister of Public Instruction, Budapest.

CSATÓ, JOHN, eminent Hungarian ornithologist, Nagy-Enyed.

CsÖRGEY, TrTUS, ornithologist and eminent bird painter, Budapest.

CzetTel, Gyula, owner of a lithographic institute, Budapest.

TDANTE, AlighIERI, great Italian poet, author of the Divina Commedia.

DARÁNYI, Dr. IGNÁCZ de, Hungarian Minister of Agriculture, founder of the system of rational bird protection in Hungary and of many institutions of advantage to the general public.

*Delcassé, Theophilus, formerly French Foreign Minister, Paris.

*Delvanni, N., Extraordinary Legate of Greece, Paris.

*Depelley, J. B., Chargé d'affaires for Monaco, Paris.

DunaY, Baron Hugo, Dunavecse.

$\triangle$ Dundas-HARFORD, Frederick, Second Sec. to the British Embassy in Paris.

ENTZ, GÉZA Dr., University Prof., well-known Hungarian zoologist, Budapest.

$\triangle$ Esterházy, Count PAUL, first Sec. of the Austro-Hungarian Embassy in Paris in 1895.

†FATIO, Victor, Prof., eminent zoologist, Geneva.

$\triangle$ Fereira, BARTOLOMEO, first Sec. of the Portuguese Legacy in Paris in 1895 .

FINSCH, Dr. OTTO, celebrated New-Guinea explorer, ornithologist and ethnograph, Delmenhorst (later Brunswick). 
Forgách, Count Charles, eminent Hungarian African traveller and ornithophaenologist, Ghymes.

tFrauenfeld, Antony Ritter von, Keeper of the Vienna Imp. Museum.

†FRIVALDSZKY, JOHN, celebrated Hungarian coleopterologist, chief of the Zoological section of the National Museum, Budapest.

†FULTON, ROBERT, inventor of the steamship.

FÜRBRINGER, Dr. MAX, University Prof. celebrated German anatomist, Jena (later Heidelberg).

GADAUT, French Minister of Agriculture in 1895, Paris.

TGAETKE, HENRY, celebrated ornithobiologist, who for 50 years observed the passage of birds on the Island of Heligoland.

$\triangle$ Gérard, ChaRles, Chef de Cabinet of the French Minister of Agriculture.

GHYCZY, BÉLA, Field-Marshal-Lieutenant ret., enthusiastic champion of birds protection, Budapest.

$\triangle$ GigliOli-Hillyer, ENRICO, celebrated Italian ornithologist, since 1884 delegate of Italy at every Ornithological Congress and Conference, Florence.

$\triangle$ GILBERT, Contrôleur des chasses, Brussels.

GioRghiefF, S., Prof., Sofia.

Girard, Charles, Chef de Cabinet of the French Ministry of Agriculture, Paris.

GiRTANNER, Dr. A., prominent Swiss ornithologist, St-Gallen.

Grobben, Dr. C., Prof. of Zoology at the Univ. of Vienna.

†D'HAMONVILLE, Baron, celebrated French ornithologist, Château Manonville.

HARTERT, Dr. ERNEST, celebrated German (later English) ornithologist, Tring.

HÁRY, GYULA, prominent painter, Budapest.

HAYEK, Dr. Gustavus, Regierungsrat, Vienna.

$\triangle$ HENNEQUiN, Chief of the Department for hunting in the French Ministry of the Interior, Paris.

Herman, OtTo, in 1891 Member of the Hungarian Parliament, later Director of the Hungarian Central Office for Ornithology. 
†Homeyer, Eugene Ferdinand von, celebrated German ornithologist, Stolp.

†HOMEYER, Major AlEXANDER von, prominent German African traveller and zoologist, Greifswalde.

†Horatius, Quintus Flaccus, prominent Latin Poet of the Augustan Age, called by Italians "Orazio".

HoRvÁTH, Dr. GÉZA, eminent Hungarian hemipterologist, Director of zool. Section at the National Museum, Budapest.

†KÁllay, BENJAmin, renowned Hungarian statesman, Austro-Hungarian Minister of Finance, organisator of Bosnia and Herzegovina.

KARGL, Champion of the protection of animals, Linz.

KeUlemans, celebrated English bird painter, London.

KERMENIČ, AURELIUS, Champion of the protection of animals, Vienna.

KOENIG, Baron RICHARD, von Warthausen, enthusiastic German ornithophaenologist, Warthausen.

$\triangle$ KoeniG, Dr. AleXander, Prof. of Zoology at the Univ. of Bonn, celebrated ornithologist.

Koppély, GÉZA, Landowner, Hatvan.

$\triangle$ Koulagin, Prof. of the Agric. Acad. in Moscow.

*LARDY, ChARLES, Extraordinary Legate and Minister Plenipotentiary of Switzerland in Paris.

LeHMANN, Geh. Legationsrat, Berlin.

†LIEBE, Dr. TH., celebrated German champion of the protection of birds, Gera.

†LIEBIG, JUSTUS, world-famed German chemist.

LÖCHERER, ANDOR, Editor, Budapest.

LORENZ, Dr. LoUIS de Liburnau, Keeper of the Imperial Museum, Vienna.

MADARÁSz, Dr. Gyula de, eminent ornithologist, Budapest.

MÁDAY, IZIDOR de Maros, Ministerial Councillor ret., Hungarian referendary of bird protection at the International Ornithological Congress of 1891, Budapest.

MALtZAN, A., hereditary Chief Chamberlain, Berlin.

$\triangle$ MARCHAND, Chef de Bureau in the French Ministry of Agriculture, Paris. 
Marenzeller, EMIL von, eminent Austrian zoologist, Keeper of the Imperial Museum, Vienna.

$\triangle$ MaXwell, Sir Herbert Eustace Bart. M. P. London.

AMAYER, LODOVICO, Chief of Cabinet, Monaco.

$\triangle$ Méline, Felix Jules, Deputy, eminent French statesman, Min. of Agriculture in the Ferri Cabinet, Paris.

MIDDENDORFF, ERNEST von, celebrated Livonian ornithologist, Hellenorm.

†MIDDENDORFF, AlEXANDER von, celebrated Russian traveller and observer of birds, St-Petersburg.

$\triangle$ MORAGaS Y UCELAY, RICHARD, Sec. of the Madrid Royal Agricultural Society, Madrid.

+NAUMANN, father and son, the family name of two celebrated German ornithologists.

†NÉCSEY, STEPHEN, painter, Verebély.

NEWTON, AlFrED, Prof., the eminent English ornithologist, Cambridge.

$\triangle$ Novallas, Marquis de, first Sec. of the Spanish Embassy at Paris in 1895, Madrid.

$\triangle$ fOustalet, Dr. EMILE, official of the Musée d'histoire naturelle, ornithologist, Paris.

PAlaCKY, Dr. JOHN, Univ. Professor, Prague.

PALlisCH, C., Engineer, Vienna.

PAlmén, J. A., Professor, eminent Finnish ornithologist, Helsingfors.

PAREY, Publisher, Berlin.

PASZlavsZKY, JOSEPH, in 1891 Principal Secretary of the Royal Hungarian Natural History Society.

†Petényi, J. SOlOMON, eminent Hungarian ornithologist, founder of Hungarian scientific ornithology.

$\triangle$ POIRSON, Chief of the Department of Public Safety in the French Ministry for Home Affairs, Paris.

Pollen, Dr. FranCis, doctor, Scheveningen.

$\triangle$ PROST, Belgian agricultural superintendent, Brussels. 
fPulszKY, FRANCIS, famous Director of the Hungarian National Museum, Budapest.

†RADDE, Dr. GUSTAVUS, celebrated traveller, Russian ornithologist, Tiflis.

*Radolin, Prince, German Ambassador, Paris.

RaOul, E., Paris.

RAVA, LUIGI, Italian Minister of Agriculture and Commerce, Rome.

REICHENOW, Dr. ANTON, eminent German ornithologist, Berlin.

RITZEMA-BOS, Dr., celebrated Prof. of the State Agricultural School at Wageningen, Holland.

tRuss, Dr. Charles, eminent German bird-fancier, Berlin.

$\triangle$ SAÁROSSY-KaPELlER, FrANCIS, Ministerial Councillor, Imp. Roy. Lord High Stewart, Budapest.

$\triangle$ SAGNIÉR, Member of the French Agricultural Society, Paris.

SALVADORI, Count THOMAS, eminent Italian ornithologist, Turin. $\triangle$ SAUNDERS, HOWARD, prominent English ornithologist, London.

SCHÄFF, Dr. ERNEST, Berlin.

†SCHRENCK, LEOPOLD von, celebrated Russian traveller, St-Petersburg.

SCHALOW, HERman, eminent German ornithologist, Berlin.

SClater, PH. LUTLEY, Keeper of the British Museum, eminent ornithogeograph, London.

$\triangle$ SELENKA, Dr., Prof. of Zoology at the University, Erlangen.

SHARPE, Dr. R. BowDLER, eminent British ornithologist, British Museum, London.

SEIDL, J., Bosewitz.

†Settegast, Dr. H., celebrated German economist and writer, Proskau.

*SouzA, RozA de, Plenipotentiary Minister of Portugal, Paris.

$\triangle$ SVERDRUP, in 1895 Equerry-in-chief to the King, Christiania.

SZALAY, IMRE, Ministerial Councillor, later Director of the Hungar ian National Museum, Budapest.

SzENICZEY, EDMUND, in 1891 Member of the Hungarian P., Budapest. 
SzILY, Dr. KÁlmáN, in 1891 Pres. of the Royal Hungarian Natural History Society, Budapest.

SzÖGYÉNY-MARICH, LADISLAS de, eminent Hungarian politician, at present Ambassador in Berlin.

Taeschlein, L., Augsburg.

TALlı́ÁN, BÉlA, formerly Hung. Min. of Agriculture, Budapest.

TALSKY, Prof. JOSEPH, Neutitschein.

TARgioni-TozetTi, Prof., Florence

THORBURN, ARCHIBALD, celebrated bird painter, London.

$\triangle$ THIEL, Dr., Geheimer Oberregierungsrat, Berlin.

TISCHER, BENEDICT, ornithologist, Augsburg.

$\triangle$ TISSERAND, FELIX, French State Councillor, Paris.

TORELLI, Italian delegate, Rome.

†TSCHUDI, FREDERICK, eminent Swiss politician and natural historian, Bern.

$\triangle$ TSCHUSI, VICTOR Ritter, de Schmidthofen, prominent Austrian ornithologist, expert adviser at the Paris Conference in 1895, Hallein.

$\triangle$ TYPALDO-BASSIA, Greek Univ. Professor, Athens.

VADAS, EugENE, Chief Councillor for Forestry, Prof. of the Academy of Forestry, eminent writer on forestry questions, Selmeczbánya.

VADÁSZFY, E., Forester, Budapest.

VALLON, Prof, Udine.

$\triangle *$ VANNERUS, in 1895 Legate of Luxemburg at Paris.

VISCONTI-VENOSTA, celebrated Italian statesman, signed „Declaration" of 1875 .

WANGELIN, JACOBY von, Regierungs- und Forstrat, one of the referendaries on the question of bird-protection at the Second Intern. Ornith. Congress, Merseburg.

†WATT, JAMES, inventor of the steam engine.

Wekerle, Dr. Alexander, P. C., Hungarian Premier, who in 1906 incorporated the Intern. Convention in the "Corpus Juris" of Hungary. 
WEŠNIAKOFF, Russian State Councillor, St-Petersburg.

WOLFFERSDORFF, E. v., Lieut-Colonel, Germany.

*WolKenSTEIN-TROSTBURG, Count, Austro-Hungarian Ambassador, Paris.

†XANTHUS, JOHN, eminent Hungarian traveller in America, Budapest.

Zeller, Frederick, Vienna.

†ZEPPELIN, Count MAX, eminent ornithologist, Stuttgart.

†ZichY, Count Francis, P. C., Budapest.

ZIMMERMANN, THEODOR, champion of the protection of animals, Königsberg i. P.

ZSELÉNSZKY, Count ROBERT, P. C., Member of the House of Magnates, Delegate of Hungary at the International Economic Institute's Congress held at Rome in 1905. 



\title{
INDEX OF BIRD-NAMES
}

\author{
(IN SIX LANGUAGES).
}





\section{Index of Bird-names.}

I thought it expedient to add a short dictionary to concentrate the names of the birds which occur in this historical sketch. The system followed is to give the English name first and to add the scientific Graeco-Latin names as well as those of the other languages concerned. In doing so I hope I shall have rendered some service to those who may in the future concern themselves with this question in its international aspects.

The sources from which I have derived the various names are

1. For the English and French names:

Dresser, H. E.: „A Manual of palaearctic Birds. London, 1902."

2. For the German names:

NAUMANN: "Naturgeschichte der Vögel Europas". Zweite Ausgabe. Bd. I-XII. Éditio HenNiCKE.

Brehm, Alfred : "Thierleben." Bd. I-X.

3. For the Italian names:

ARRIGONI DEGLI ODDI, conte: "Manuale di Ornithologia Italiana. 1904." 
Explanation of signs :

$\mathrm{O}=$ protected in Hungary.

$L .=($ Graeco-)Latin scientific name.

$F$. $=$ French name.

$G .=$ German name.

$I_{\text {. }}=$ Italian name.

$H .=$ Hungarian name.

- ? - , the name in this particular language is unknown to me.

OAccentor, Alpine, v. Alpine Accentor.

Adriatic Gull. L. Larus melanocephalus Nat. $F$. Goéland mélanocéphale. G. Mohren-Möve. $I$. Gabbiano corallino. $H$. Szerecsensirály.

Albatross. $L$. Diomedea exulans. F. Albatros. G. Kapschaf. - ?$H$. Tengeri behemót.

OAlpine Accentor. $L$. Accentor alpinus. $F$. Fauvette des Alpes. $G$. Alpen-Fluevogel. I. Sordone. $H$. Havasi szürkebegy.

Alpine Finch. $L$. Fringilla nivalis. $F$. Pinson des Alpes. $G$. Schneefink. I. Fringuello alpino. $H$. Havasi pinty.

Alpine Ptarmigan. L. Lagopus mutus. $F$. Perdrix blanche. $G$. Schneehuhn. I. Pernice bianca. $H$. Hófajd.

Alpine Swift. L. Cypselus melba. F. Grand Martinet. G. Alpensegler. $I$. Rondone alpino. $H$. Havasi fecske.

American Quail. L. Ortyx virginianus Gould. - ?- G. Baumwachtel. I. Quaglia virginiana. $H$. Amerikai fürj.

Aquatic Warbler. L. Calamodus aquaticus. - ?- - ?- I. Pagliardo. H. Csikosfejü sitke.
Arctic Skua. $L$. Stercorarius crepidatus Banks. $F$. Labbe parasite. G. Schwarze Raubmöve. I. Labbo coda lunga. $H$. Élősdi halfarkas.

Auk. L. Alca torda. F. Pingouin macroptère. G. Tordalk. I. Gazza marina. $H$. Alka.

Auk, Little, v. Murre.

Avocet. $L$. Avocetta recurvirostra. $F$. Avocette à nuque noire. $G$. Avosett-Säbler. I. Avozetta. H. Gulipán.

OAzure Titmouse. $L$. Parus cyanus Pall. - ?- $G$. Lazurmeise. I. Cinciarella cyana. $H$. Lazurczinege.

OBarn Owl. $L$. Strix flammea. $F$. Effraie. $G$. Schleiereule. I. Barbagianni. $H$. Gyöngybagoly.

CBarred Warbler. L. Sylvia nisoria Bechst. $F$. Fauvette épervière. $G$. Sperbergrasmücke. I. Bigia padovana. $H$. Karvalyposzáta.

OBarred Woodpecker. L. Dendrocopus minor. $F$. Pic épie chette. $G$. Kleiner Buntspecht. I. Picchio rosso minore. $H$. Kis fakópáncs.

Bar-tailed Godwit. L. Limosalapponica. $F$. Petite Barge. $G$. Kleine Uferschnepfe. I. Pittima minore. $H$. Kis goda. 
Bean Goose. $L$. Anser fabalis Lath. $F$. Oie vulgaire. $G$. Saatgans. $I$. Oca granaiola. $H$. Vetési lúd.

Bearded Reedling. L. Panurus biarmicus. $k$. Mésange à moustaches. $G$. Bartmeise. I. Basettino. $H$. Bajszos czinege, Szakállas czinege.

Bearcied Vulture. L. Gypaëtos barbatus. F. Gypaète barbu. $G$. Bartgeier. I. Avvoltoio degli agnelli. $H$. Szakállas saskeselyü. Bee-eater. $L$. Merops apiaster. $F$. Guêpier. $G$. Bienenfresser. $I$. Gruccione. H. Gyurgyóka.

Bittern. L. Botaurus steliaris. $F$. Grand Butor. G. Rohrdommel. I. Tarabuso. H. Bölömbika.

Bittern, Little, v. Little Bittern. Black-belied Sand-Grouse. $L$. Pterocles arenarius Pall. $F$. Corticole. G. Sandhuhn. I. Ganga. $H$. Pusztai tyúk.

Blackbird. $L$. Turdus merula. $F$. Merle noir. G. Schwarzamsel. $I$. Merlo nero. $H$. Fekete rigó.

CBlackcap. L. Sylvia atricapilla. $F$. Fauvette à tête noire $G$. Mönchgrasmücke. I. Capinera. H. Barátkaposzáta.

Black Crow. L. Corvus corone. $F$. Corneille noir. G. RabenKrähe. $I$. Cornacchia nera. $H$. Fekete varjú.

Black Grouse. $L$. Tetrao tetrix F. Tetras lyrée. G. Birkhuhn. I. Fagione di monte. $H$. Nyirfajd.

OBlack-headed Gull. L. Larus rudibundus. $F$. Goéland rieur. $G$. Lachmöve. $I$. Gabbiano commune. $H$. Dankasirály.

OBlack-headed Wagtail. L. Motacilla melanocephala Liecht. -?- G. Schwarzköpfige Bach- stelze. $I$. Cutrettola capinera. $\boldsymbol{H}$. Kucsmás billegető.

Black Kite. L. Milvus migrans. $F$. Milan noir. G. Schwarzer Milan. $I$. Nibbio bruno. $H$. Fekete kánya.

OBlack Redstart. L. Ruticilla titis. $F$. Rougequeue des Murailles. G. Hausrotschwanz. 1. Codirosso spazzacamino. $H$. Házifüstfark. Black Scoter. $L$. Oidemia nigra. F. Macreuse. G. Trauerente. I. Orchetto marino. $H$. Fekete récze. CBlack Stork. L. Ciconia nigra. $F$. Cigogne noire. $G$. Schwarzer Storch. I. Cicogna nera. $H$. Fekete gólya.

C Black Tern. L. Hydrochelidon nigra. $F$. Guifette noire. $G$. Schwarze Seeschwalbe. I. Mignattino. $H$. Kormos szerkö.

Black-throated Diver. L. Colymbus arcticus. $F$. Plongeon à gorge noire. $G$. Polartaucher. I. Strolaga mezzana. $H$. Sarki buvár.

Black Vulture. $L$. Vultur monachus. $F$. Vautour moin. $G$. Kuttengeier. I. Avvoltoio. H. Barátkeselyü.

Black-winged Stilt. L. Himantopus candidus, Bonnat. $F$. Échasse blanche. G. Strandreiter, Stelzenläufer. $I$. Cavalier d'Italia. $H$. Gólyasnef.

Black Woodpecker. L. Dryo copus martius. $F$. Pic noir. $G$. Schwarzspecht. I. Picchio nero. $H$. Fekete harkály.

OBlue-headed Wagtail. L. Motacilla flava. $F$. Bergeronette printannière. $G$. Gelbe Bachstelze. $I$. Cutrettola gialla. $H$. Sárga billegető.

Bluethroat, Red-spotted, v. Redspotted Bluethroat.

CBlue Thrush. L. Monticola so- 
litaria. $F$. Pétrocincle blue. $G$. Blaumerle. I. Passera solitaria. H. Kék kövirigó.

OBlue Titmouse. $I$. Parus coeruleus. $F$. Mésange bleue. $G$. Blaumeise. $I$. Ciciarella. $H$. Kék czinege.

OBonelli's Warbler. L. Phylloscopus Bonellii. $F$. Becfin-Bonelli. $G$. Berglaubvogel. I. Lui bianco. $H$. Bonelli füzike.

Bonxie, v. Great Skua.

OBramble-finch, v. Brambling.

OBrambling. $L$ Fringilla montifringilla. $F$. Pinson d'Ardennes $G$. Bergfink. $I$. Peppola. $H$. Fenyőpinty.

Brent Goose. $L$. Branta bernicla. $F$. Bernache cravant. $G$. Ringelgans. $I$. Oca colombaccio. $H$. Örvöslúd.

Buff-backed Heron. $L$. Ardea bubulcus. $F$. Héron garde-boeuf. G. Kuhreiher. I. Airone garda buoi. $H$. Pásztorgém.

Buffon Skua. $L$. Stercorarius parasiticus. $F$. Labbe à longue queue. $G$. Kleine Raubmöve. $I$. Labbo. $H$. Nyílfarkú halfarkas.

Bullfinch. $L$. Pyrrhula pyrrhula. F. Bouvreuil. G. Dompfaff. $I$. Ciuffolotto maggiore. $H$. Süvöltő.

Bunting. $L$. Emberiza. $F$. Bruant G. Ammer. I. Zigolo. H. Sármány.

Bunting, Cirl, v. Cirl Bunting.

OBunting, Corn, v. Corn Bunting. OBunting, Meadow, v. Meadow Bunting.

OBunting, Reed, v. Reed Bunting. OBunting, Snow, v. Snow Bunting.

Bustard. L. Otis tarda. F. Outard G. Grosstrappe $I$. Otarda. $H$. Túzok.

Bustard, Houbara, v. Houbara Bustard.

Bustard, Little, v. Little Bustard.
Buzzard. $L$. Buteo buteo. $F$. Buse vulgaire. $G$. Mäusebussard. $I$. Pojana. $H$. Egerészölyv.

Buzzard, Honey, v. Honey Buzzard.

Buzzard, Rough-legged,v. Roughlegged Buzzard.

Capercailly, Capercailzie. $L$. Tetrao urogallus. $F$. Coq de bruyère. G. Auerhahn. I. Gallo cedrone. $H$. Siketfajd.

Caspian Tern. $L$. Sterna caspia Pall. $F$. Sterne tschegrava. $G$. Raub-Seeschwalbe. I. Rondine di mare maggiore. $H$. Lócsér.

Caucasian Rose-finch. L. Carpodacus rubicilla. $F$. Roselin de Caucase. $G$. Rosengimpel. $I$. Ciuffolotto. $H$. Rózsapirók.

Chaffinch. L. Fringilla coelebs. $F$. Pinson ordinaire. G. Buchfink, Edelfink. $I$. Fringuello. $H$. Pintyőke.

Chiffchaff. L. Phylloscopus acredula. $F$. Becfin veloce. $G$. Weidenlaubvogel. $I$. Lui piccolo. $H$. Csil-csal füzike.

Chough, Cornish, v. Cornish Chough.

Cirl Bunting. L. Emberiza cirlus. $F$. Bruant zizi. G. Zaunammer. $I$.Zigolo nero. $H$. Sövénysármány.

OCoal Titmouse. L. Parus ater. $F$. Mésange noire. $G$. Tannenmeise. $I$. Cincia mora. H. Fenyves czinege.

Colin, v. American Quail.

Common Crossbill. $L$. Loxia curvirostra. $F$. Bec-croisé. G. Kreuzschnabel. $I$. Crociere delle pinete. $H$. Keresztcsőrü.

Common Gull. L. Larus canus. $F$. Goéland cendré. G. SturmMöve. I. Gavina. H. Viharsirály.

Common Tern. $L$. Sterna hirundo. F. Pierre Garin. G. Fluss-Meer- 
schwalbe. $I$. Rondine di mare. $H$. Küszvágó csér.

Coot. $L$. Fulica atra. F. Foulque noire. $G$. Blässhuhn. I. Folaga. H. Szárcsa.

Cormorant. L.Phalacrocorax carbo. $F$. Grand Cormoran. G. Kormoran-Scharbe. $I$. Marangone. $H$ Kárakatna.

Corn Bunting. L. Emberiza calandra. F. Bruant Proyer. $G$. Grauammer. I. Strillozzo. $H$. Sordély.

Corncrake. $L$. Crea pratensis Bechst. $F$. Râle des prés. $G$. Wachtelkönig. $I$. Re di quaglie. $H$. Haris.

Cornish Chough. L. Pyrrhocorax graculus $\mathrm{Cm}$. F. Crave. G. Steindohle. I. Gracchio. H. Havasi csóka.

Courser, Cream-coloured, v. Cream-coloured Courser.

Crake, Little, v. Little Crake.

Crake, Pigmy, v. Pigmy Crake.

Crake, Spotted, v. Spotted Crake.

Crane. $L$. Grus cinerea. F. Grue. G. Kranich. I. Gru. H. Daru.

Cream-coloured Courser. $L$. Cursorius gallicus. $\boldsymbol{F}$. Courvite isabelle. G. Rennvogel. I. Corrione biondo. $H$. Futólile.

Creeper, Tree, v. Tree Creeper.

Creeper, Wall, v. Wall Creeper.

Crested Lark. L. Alauda cristata. F. Cochevis huppée. G. Schopflerche. 1. Cappellaccia. $H$. Búbos pacsirta.

Crested Titmouse. $L$. Parus cristatus. $F$. Mésange hupée. G. Haubenmeise. $I$. Cincia col ciuffo. $H$. Búbos czinege.

Crossbill, Common, v. Common Crossbill.

Crossbill, Two barred, v. Twobarred Crossbill.
Crow. L. Corvus. $F$. Corbeau. G. Krähe. I. Corvo. H. Varjú.

Crow, Black, v. Black Crow.

Crow, Grey, v. Grey Crow.

O Cuckoo. $L$. Cuculus canorus. $\boldsymbol{F}$. Coucou chanteur. G. Kukuk. $I$. Cuculo. H. Kakuk.

Curlew. $L$. Numenius arcuatus. $F$. Courlis. Gr. Sichler, Brachvogel. I. Chiurlo maggiore. $H$. Póling.

Curlew, Pigmy, v. Pigmy Curlew.

Curlew, Slender-billed, v. Slenderbilled Curlew.

Curlew, Stone, v. Thickknee.

ODipper. $L$. Cinclus cinclus. $\boldsymbol{F}$. Merle d'eau. G. Wasseramsel. I. Merlo aquaiolo. $H$. Vízirigó.

Diver, Black-throated, v. Blackthroated Diver.

Diver, Great Northern, v. Great Northern Diver.

Diver, Red-throated, v. Loon.

ODotterel. L. Chardrius morinellus. $F$. Pluvier guignard. G. Mornell Regenpfeifer. $I$. Piviere tortolino. $H$. Havasi lile.

Double Snipe. L. Gallinago maior Gm. $F$. Grande Bécassine. $G$. Doppelschnepfe. I. Croccolone. $H$. Nagy sárszalonka.

Dove. L. Columba. F. Pigeon. $G$. Taube. I. Picchione. $H$. Vadgalamb.

Dove, Rock, v. Rock Dove.

Dove, Stock, v. Stock Dove.

Duck, Long-tailed, v. Long-tailed Duck.

Duck Tufted, v. Tufted Duck.

Duck, White-eyed, v. White-eyed Duck.

Duck White-headed, v. Whiteheaded Duck.

Duck, Wild, v. Wild Duck.

Dunlin. $L$. Tringa alpina. $F$. Bécasseau variable. $G$. Alpen-Strand- 
läufer. I. Piovanello pancia nera. $H$. Havasi partfutó.

Eagle. $L$. Aquila. $k$. Aigle. $G$. Adler. I. Aquila. H. Sas.

Eagle, Golden, v. Golden Eagle. Eagle, Greater spotted,v. Greater spotted Eagle.

Eagle Owl. L. Bubo bubo, Bubo maximus. $F$. Grand duc. $G$. Uhu. I. Gufo reale. $H$. Buhu, Nagy fülesbagoly.

Eagle, Sea, v. Sea Eagle.

Eagle, Short-toed, v. Short-toed Eagle.

Eared Grebe. L. Podiceps nigricollis Brehm. $F$. Grébe oreillard. G. Geöhrter Steissfuss. I. Svasso piccolo. H. Feketenyakú vöcsök.

Egret, Great White, v. Great White Egret.

Egret, Little, v. Little Egret.

Egyptian Vulture. L. Neophron percnopterus. $F$.Vautour d'Égypte. $G$. Schmutziger Aasgeier. I. Capovaccio. $H$. Dögkeselyü.

Eider. $L$. Somateria mollissima. F. Morillon. (i. Eidergans. $I$. Edredone. $H$. Dunnalúd.

Falcated Teal, $L$. Anas falcata Georgi.-?- G. Sichelente.-?H. Sarlós rucza.

Falcon. L. Falco. $k$. Faucon. $G$. Falke. $I$. Falco. $H$. Sólyom.

Falcon, Peregrine, v. Peregrine Falcon.

OFalcon, Red-legged, v. Redlegged Falcon.

Fern Owl, v. Nightjar.

Fieldfare. $L$. Turdus pilaris. $\boldsymbol{F}$. Grive Litorne. G. Wacholderdrossel. I. Cesena. H. Fenyörigó.

OFinch, Alpine, v. Alpine Finch.

OFinch, Bramble, v. Brambling.

CFire-crested Wren. I. Regu- lus ignicapillus Brehm. F. Roitelet à triple bandeau. $G$. Feuerkopf-Goldhähnchen. I. Fioranzino $H$. Tüzesfejü királyka.

Flamingo. $L$. Phoenicopterus antiquorum. $F$. Flamant rose. $G$. Rosenfarbiger Flamingo. I. Fenicottero. $H$. Flamingó.

Flycatcher. L. Muscicapa. F. Gobemouche. $G$. Fliegenfänger. $I$. Balia. H. Légykapó.

OFlycatcher, Pied, v. Pied Flycatcher.

OFlycatcher, Red-breasted, v. Red-breasted Flycatcher.

OFlycatcher, Spotted, v. Spotted Flycatcher.

Flycatcher, White-collared, v. White-collared Flycatcher.

Francolin. $L$. Francolinus vulgaris Steph. F. Francolin. G. Francolinhuhn. $I$. Francolino. $H$. Frankolin.

Frigate-bird. $L$. Tachypetes aquilus Vieill. Fregata. $F$. Frègate. G. Fregatt-Vogel. - ?- H. Tengeri sas.

Fulmar. L. Fulmarus glacialis Steph. F. Pétrel Fulmar. G. Eissturmvogel. - ?- H. Sirályhojsza.

Furze-chat. L. Pratincola. $F$. Tarier. $G$. Wiesenschmätzer. I. Stiaccino. H. Csaláncsúcs.

Gadwall. L. Chaulelasmus streperus. $F$. Chipeau bruyant. $G$. Schnatterente. I. Canapiglia. $\boldsymbol{H}$. Kendermagos rucza.

Gallinule, Purple, v. Purple Gallinule.

Gannet. $L$. Sula bassana. $F$. Fou de Bassan. G. Basstölpel $I$. Sula. H. Buta szula.

Garden Redstart. $L$. Ruticilla phoenicura. $F$. Rouge-queue. $G$. Gartenrotschwanz. I. Codirosso $H$. Kerti füstfark. 
Garden Warbler. L. Sylvia simplex. $F$. Fauvette des jardins. $G$. Gartengrasmücke. I. Beccafico. $H$. Kerti poszáta.

Garganey. $L$. Aras querquedula. $F$. Sarcelle d'été. G. Knäkente. I. Marzaiola. $H$. Böjti rucza.

Glossy Ibis. $L$. Ibis falcinellus. $F$. Ibis falcinelle. $G$. Dunkler Ibis. I. Mignattaio. $H$. Batla.

Goatsucker, v. Nightjar.

Godwit. L. Limosa limosa. $\boldsymbol{F}$. Barge. $G$. Uferschnepfe. I. Pittina reale. $H$. Goda.

Godwit, Bar-tailed, v. Bar-tailed Godwit.

Golden-crested Wren. L. Regulus regulus. $F$. Roitelet ordinaire. G. Gelbkopf-Goldhähn. chen. $I$. Regolo. $H$. Sárgafejü királyka.

Golden Eagle. L. Aquila chrysaëtus. $F$. Aigle royal. $G$. Steinadler, Goldadler. $I$. Aquila reale. $H$. Szirti sas.

Golden-eye. $L$. Fuligula clangula. $F$. Garrot. $G$. Schellente. $I$. Quattr'occhi. H. Kercze rucza.

Golden Oriole. $L$. Oriolus galbula. F. Loriot. G. Goldamsel. I. Pirol; Rigogolo. H. Aranymálinkó.

Golden Plover. $L$. Charadrius pluvialis. $F$. Pluvier doré. $G$. Gold-Regenpfeifer. I. Piviere dorata. $H$. Pettyes lile.

Goldfinch. $L$. Carduelis carduelis. F. Chardonneret. G. Stieglitz. I. Cardellino. $H$. Tengelicz. Goosander. $L$. Mergus merganser. F. Grande Harle. G. Grosser Säger. $I$. Smergo maggiore. $H$. Muszkabuvár.

Goose, Bean, v. Bean Goose.

Goose, Brent, v. Brent Goose.

Goose, Greylag, v. Greylag Goose.
Goose, White-fronted, v. Whitefronted Goose.

Goshawk. L. Astur palumbarius. $F$. Autour. $G$. Hühnerhabicht. $I$. Astore. $H$. Héja.

Orasshopper Warbler. L. Locustella naevia Bodd. - ?- G. Heuschreckensänger, Schwirl. I. Forapaglie macchiettato. $H$. Réti tücsökmadár.

Greatcrested Grebe. L. Podiceps cristatus Lath. $F$. Grebe huppé. $G$. Haubensteissfuss. I. Svasso maggiore. $H$. Búbos vöcsök.

Greater Spotted Eagie. L. Aquila maculata Gm. $F$. Aigle criard. $G$. Schreiadler. I. Aquila anatraia maggiore. $H$. Békászó sas.

Great Grey Shrike. L. Lanius excubitor. $\boldsymbol{F}$. Pie-grieche grise. $G$. Grosser Würger. I. Averla maggiore. $H$. Örgébics.

Great Northern Diver. $L$. Colymbus glacialis. $F$. Plongeon imbrim. G. Eisseetaucher, Imbergans. $I$. Strolaga maggiore. $H$. Jeges búvár.

OGreat Red Warbler. L. Acrocephalus arundinaceus. $F$. Rousserolle. G. Rohrdrossel. I. Cannareccione. $H$. Nádirigó.

Great Skua. $L$ Lestris catarrhactes. $F$. Labbe cataracte. $G$. Grosse Raubmöve. I. Stercorario maggiore. $H$. Halfarkas.

Great Titmouse. L. Parus maior. $F$. Mésange charbonnière. $G$. Kohlmeise. I. Cinciallegra. $H$. Szénczinege.

Great White Egret. L. Ardea alba. $F$. Héron Aigrette. $G$. SilberReiher. I. Airone bianco maggiore. $H$. Lovas kócsag.

Grebe, Eared, v. Eared Grebe.

Grebe, Great-crested, v. Great crested Grebe. 
Grebe, Little, v. Little Grebe.

Grebe, Red-necked, v. Red-necked Grebe.

Greek Partridge. L. Caccabis saxatilis W. M. F. Bartavelle. $G$. Steinhuhn. $I$. Coturnice. $H$. Szirti fogoly.

CGreenfinch. $L$. Ligurinus chloris. $F$. Verdier ordinaire. G. Grünling. $I$. Verdone. $H$. Zöldike.

Green Sandpiper. $L$. Totanus ochropus. $F$. Chevalier cul-blanc. G. Punktierter Wasserläufer. $I$. Piropiro cul-bianco. H. Erdei czankó.

Greenshank. L. Totanusnebularius Gunn. $F$. Chevalier gris. G. Grünfuss-Wasserläufer. I. Pantana. $H$. Szürke czankó.

OGreen Woodpecker. L. Picus viridis. $F$. Pic vert. G. Grünspecht. $I$. Picchio verde. $H$. Zöld küllö.

Grey Crow. $L$. Corvus cornix. $F$. Corneille mantelée.G. Nebelkrähe. I. Cornacchia. H. Dolmányos varjú.

Grey-headed Woodpecker. $L$. Picus canus. $F$. Pic cendré. $G$. Grauspecht. I. Picchio cenerino. $H$. Szürke küllö.

Grey Heron. $L$. Ardea cinerea. $F$. Héron huppé. $G$. Grauer Reiher. $I$. Airone cenerino. H. Szürke gém.

Greylag Goose. $L$. Anser cinereus. $F$. Oie ccndrée. $G$. Graugans. $I$. Oca selvatica. $H$. Nyári vadlúd.

Grey Phalarope. L. Phalaropus fulicarius. $F$. Phalarope gris. $G$. Plattschnäbliger Wassertreter. $I$. Falaropo a becco largo.H.Szárcsa víztaposó.

$\bigcirc$ Grey Plover. $L$. Charadrius squatarola. $F$. Vanneau-Pluvier. $G$. Kibitz-Regenpfeifer. I.Pivieressa. $H$. Ujjas lile.
OGrey Wagtail. L. Motacilla boarula Temm. $F$. Bergeronette grise. $G$ Graue Bachstelze. I. Ballerina gialla. $H$. Hegyi billegetö, Leánykamadár, Leánykabillegető.

Griffon Vulture. L. Gyps fulvus. $F$. Vautour Griffon. G. Gänsegeier. $I$. Griffone. $H$. Fakó keselyü.

Grosbeak, Pine, v. Pine Grosbeak.

Grouse. L. Tetrao. F. Tétras. G. Auerwild. $I$. Tetraone. $H$. Fajd.

Grouse, Black, v. Black Grouse.

Guillemot. $L$. Alca troile. $F$. Guillemot troile. $G$. Lumme. $I$. Uria. $H$. Hülye lumma, Uria.

Gull. $L$. Larus. $F$. Goéland. $G$. Möve. $I$. Gabbiano. $H$. Sirály.

Gull, Adriatic, v. Adriatic Gull.

OGull, Black-headed, v. Blackheaded Gull.

Gull, Common, v. Common Gull.

Gull, Herring, v. Herring Gull.

Gull, Lesser black-headed, v. Lesser black-headed Gull.

Gull, Little, v. Little Gull.

Harrier. $L$. Circus. F. Busard. $G$. Weihe. $I$. Albanella. $H$. Réti héja.

Harrier, Hen, v. Hen Harrier.

Harrier, Marsh, v. Marsh Harrier.

Harrier, Montague's, v. Montague's Harrier.

Harrier, Pallid, v. Pallid Harrier.

Hawfinch. $L$. Coccothraustes vulgaris. $F$. Grosbec vulgaire. $G$. Kernbeisser. I. Frosone. H. Meggyvágó, Vasorrú.

Hawk. $L$. Astur. $F$. Autour. $G$. Habicht. I. Astore. H. Ölyv.

Hawk, Night, v. Nightjar.

Hawk Owl. $L$. Surnia ulula. $F$. Chouette. G. Sperbereule. -?$H$. Karvalybagoly.

Hawk, Sparrow, v.Sparrow-Hawk. 
Hazel Hen. $L$. Tetrao bonasia. $F$. Gelinotte. G. Haselhuhn. I. Francolino di monte. $H$. Császárfajd.

OHedge-sparrow. L.Accentor modularis. $F$. Mouchet. G. HeckenBraunelle. I. Passera scopaiola. $H$. Erdei szürkebegy.

Hen Harrier. $L$. Circus cyaneus. F. Busard St. Martin. G. Kornweihe. $I$. Albanella reale. $H$. Kékes rétihéja.

Hen, Hazel, v. Hazel Hen.

Heron. $L$. Ardea. $F$. Héron. $G$. Reiher. $I$. Airone. $H$. Gém.

Heron, Buff-backed, v. Buffbacked Heron.

Heron, Grey, v. Grey Heron.

Heron, Night, v. Night Heron.

Heron, Purple, v. Purple Heron.

Heron, Squacco, v. Squacco.

Herring Gull. L. Larus argentatus Brün. $F$. Goèland argenté. G. Silbermöve. I. Gabbiano reale nordico. $H$. Ezüstös sirály.

Hobby. $L$. Falco subbuteo. $F$. Hobereau. G. Lerchenfalk. I. Lodolaio. H. Kaba.

Honey Buzzard. L. Pernis apivorus. $F$. Buse bondrée. $G$. Wespenbussard. I Falco pecchialolo. $H$. Darázsölyv.

Hoopoe. $L$.Upupa epops. $F$. Huppe vulgaire. $G$. Wiedehopf. I.Upupa. $H$. Búbos banka.

Houbara Bustard. $L$. Otis houbara Jacq. $F$. Houbara Outarde. $G$. Kragentrappe. I. Oubara. $H$. Galléros túzok.

House-Martin. L. Chelidon urbica. $F$. Hirondelle de fenêtre. G. Hausschwalbe. I. Balestruccio. $H$. Házifecske, Molnárfecske.

Ibis, Glossy, v. Glossy Ibis.

Icterine Warbler. $L$. Hypolais hypolais. $F$. Becfin à poitrine jaune. G. Gelber Spottvogel. I. Canapino maggiore. $H$. Geze.

Italian Sparrow. $L$. Passer Italiae Vieill. $F$. Moineau cisalpin. $G$. Italienischer Sperling. $I$. Passera. $H$. Olasz veréb.

OJackdaw. L. Corvus monedula. $F$. Choucas gris. G. Dohle. I. Taccola. H. Csóka.

Jack Snipe. $L$. Gallinago gallinula. $F$. Bécassine sourde. $G$. Halbschnepfe. $I$. Frullina. $H$. Kis sárszalonka.

Jay. $L$. Garrulus glandarius. $k$. Geai ordinaire. G. Eichelhäher. I. Chiandala. H. Szajkó.

OKentish Plover. L. Charadrius alexandrinus. $F$. Pluvier à collier interrompu. G. See-Regenpfeifer. $I$. Fratino. $H$. Széki lile.

OKestrel. $L$. Cerchneis tinnunculus. $F$. Cresserelle. $G$. Turmfalk. I. Gheppio. H. Vörösvércse.

OKestrel, Naumann, v. Naumann Kestrel.

Kingfisher. $L$. Alcedo ispida. $F$. Martin-pêcheur. G. Eisvogel. I. Martin piscatore. $H$. Jégmadár.

Kite. $L$. Milvus. $F$. Milan. $G$. Milan. I. Nibbio. H. Kánya.

Kite. $L$. Milvus milvus. $F$. Milan Royal. G. Roter Milan. I. Nibbio reale. $H$. Vöröskánya.

Kite, Black, v. Black Kite.

Kittiwake. $L$. Rissa trydactyla. $F$. Mouette tridactyle. $G$. Dreizehige Möve. $I$. Gabbiano tridattilo. $H$. Háromuijú csüllö.

Kivi. L. Apteryx australis, Shaw. Knot. $L$. Tring a canutus. $F$. Bécasseau maubèche. $G$. Rostiger Strandläufer. $I$. Piovanello maggiore. $H$. Izlandi partfutó.

Landrail, v. Corncrake.

Capwing. $L$. Vanellus vanellus. 
F. Vanneau dixhuit. (i. Kiebitz.

I. Pavoncella. H. Bibicz.

OLark, Crested, v. Crested Lark.

OLark, Shore, v. Sinore-Lark.

CLark, White-winged, v. Whitewinged Lark.

OLark, Wood, v. Wood Lark.

Lesser black-headed Guil. L. Larus fucus. $F$. Goéland à pieds jaunes. $(r$. Heringsmöve. $I$. Zaffeiano. $H$. Heringsirály.

Lesser Grey, Shrike, v. Shrike Lesser Grey.

OLesser Whitethroat. L. Sylvia curruca. $F$. Becfin babillard. $G$. Zaungrasmücke. $I$. Bigiazella. $H$. Kis poszáta.

OLinnet. $L$. Cannabina cannabina. $F$. Linotte. $G$. Bluthänfling. $I$. Fanello. $\boldsymbol{H}$. Kenderike.

Litțle Auk, v. Murre.

Little Bittern. $L$. Ardeetta minuta. $F$. Héron blongois. $G$. Zwergrohrdommel. I. Tarabusino. $H$. Poczgém.

Little Bustard. L. Otis tetrax. $F$. Outarde canepetière. G. Zwergtrappe. I. Gallina prataiola. $H$. Reznek.

Little Crake. $L$. Ortygometra parva Scop. $F$. Poule d'eau poussin. G. Kleines Rohrhuhn. I. Schiribilla. $H$. Kis vizicsibe.

Little Egret. $L$. Ardea garzetta. $F$. Héron garzette. $G$. Kleiner Silberreiher. I. Garzetta. H. Fattyú kócsag.

Little Grebe. $L$. Podiceps minor Tunst. F. Castagneux. G. Kleiner Steissfuss. $I$. Tuffetto. $H$. Kis vöcsök.

Lit̂́le Gull. $L$. Larus minutus. $F$. Muette pygmée. G. Zwergmöve. $I$. Gabbianello. $H$. Kis sirály.

OLittle Owl. L. Glaucidium noctuum. $F$. Chevêche. $G$. Todten- vogel, Kauz. I. Civetta. H. Kuvik.

OLittle Ringed Plover. I. Charadrius dubius Scop. $F$. Petit Pluvier à collier. G. Fluss-Regenpfeifer. I. Corriere piccolo. $\boldsymbol{H}$. Kis lile.

OListle Stint. l. Tringa minuta Leisl. $F$. Bécasseau minute. $G$. Kleinèr Strandläufer. I. Gambecchio. H. Apró partfutó.

Little Tern. $L$. Sterna minuta. $\boldsymbol{F}$. Sterne naine. G. Zwerg-Seeschwalbe. I. Fraticello. H. Kis csér.

Long-eared Owl. L. Asio otus. $F$. Hibou vulgaire. (7. Waldohreule. $I$. Gufo comune. $H$. Erdei fülesbagoly.

Long-tailed Duck. L.Fuligula hyemalis. $F$. Harelde glaciale. $G$. Eisente. I. Moretta codone. $\boldsymbol{H}$. Jeges rucza.

OLongtailed Titmouse. L. Aegithalus caudatus. $F$. Mesange à longue queue. G. Schwanzmeise. I. Codibugnolo testa bianca. $H$. Öszapó, Rudas czinke.

Loon. L. Colymbus septentrionalis. $F$. Plongeon catmarin. G. Nordseetaucher. $I$. Strolaga minore H. Északi bukó, Északi buvár. Magpie. $L$. Pica rustica. $F$. Pie ordinaire. G. Elster. T. Gazza. H. Szarka.

Mallard, v. Wild Duck.

Manx Shearwater, v. Shearwater.

Marsh Harrier. L. Circus aeruginosus. $F$. Busard des marais. G. Rohrweihe. I. Albanella. $H$. Barna réti héja.

Marsh Sandpiper. $l$. Totanus stagnatilis Bechst. F. Chevalier stagnatile. $G$. Teich-Wasserläufer. I. Albastrello. H. Tavi czankó.

Marsh Titmouse. L. Parus palustris. $F$. Mésange nonnette. $G$. 
Sumpfmeise. $I$. Cincia bigia. $H$. Barátczinege.

OMarsh Warbler. L. Acrocephalus palustris Bechst. $F$. Rousserolle verderolle. $G$. Sumpfrohrsänger. $J$. Cannaiola verdognola. $H$. Énekes nádiposzáta.

Martin, House, v. House-Martin. Martin, Sand, v. Sand Martin.

OMeadow Bunting. L. Emberiza cia. F. Bruant fou. G. Zippammer. I. Zigolo muciatto. H. Bajszos sármány.

Mealy Redpoll. L. Cannabina linaria. $F$. Sizerin boréal. $G$. Leinfink. $I$. Organetto. $H$. Nyiri zseze.

Merganser, v. Goosander.

Merlin. $L$. Falco merillus Ger. $F$. Faucon émerrillon. G. Zwergfalk. $I$. Imeriglio. $H$. Kis sólyom. Middle Spotted Woodpecker. $L$. Dendrocopus medius. $F$. Picmar. G. Mittelspecht. I. Picchio rosso mezzano. $H$. Középső fakopáncs.

Mistletoe Thrush. $L$. Turdus viscivorus. $F$. Draine. G. Misteldrossel. I. Tordela. H. Léprigó.

Montague's Harrier. L. Circus pygargus. $F$. Busard cendré. $G$. Weisenweihe. I. Albanella minore. $H$. Hamvas réti héja.

Moorhen. L. Gallinula chloropus. $F$. Poule d'eau. G. Teichhuhn. $I$. Gallinella d'acqua. $H$. Vizityúk. Murre. $L$. Mergulus alle Vieil. $F$. Guillemot nain. G. Krabbentaucher. $I$. Gazza marina minore. $H$. Rákevö.

Mustached Swamp Warbler. $L$. Lusciniola melanopogon Tem. $F$. Amnicole à moustaches noires. G. Tamariskensänger. I. Forapaglie castagnolo. $H$. Fülemüle sitke.

Herman: Conv. for the Prot. of Birds.
ONaumann Kestrel. $L$. Cerchneis Naumanni. $F$. Faucon cresserine. $G$. Naumann-Falke. I. Falco grillaio. $H$. Fehérkörmű vércse.

Night Hawk, v. Nightjar.

Night Heron. L. Nyctycorax nycticorax. $F$ Héron bihoreau. $G$. Nachtreiher. $I$. Nitticora. $H$. Vakvarjú.

ONightingale. $L$. Luscinia luscinia. $F$. Rossignol. G. Nachtigall. $I$. Rusignolo. $H$. Kis fülemüle.

Nightingale, Thrush, v. Thrush Nightingale.

ONighijar. L. Caprimulgus europaeus. $F$. Engoulevent. $G$. Ziegenmelker. I. Succia capre. $\boldsymbol{H}$. Kecskefejö.

Nile Tern. $L$. Sterna nilotica Hasselqu. $F$. Sterne rieuse. $G$. Lachseeschwalbe $I$. Fondino di mare gambe nere. $H$. Kaczagó csér. Noddy. L. Anous stolidus Leach. -?- G. Dumme Seeschwalbe. -? - H. Buta szerkő.

Nut́cracker. L. Nucifraga caryocatactes. $F$. Casse-noix. G. Nusshäher. $I$. Nocciolaia. $H$. Mogyorószajkó.

Nuthatch. $L$. Sitta europaea. $\boldsymbol{F}$. Sitelle G. Spechtmeise. I. Picchio muratore. $H$. Csuszka.

COriole, Golden, v. Golden oriole.

Orphean Warbler. $L$ Sylvia orphea Tem. F. Fauvette orphée. $G$. Orpheus Grasmücke. I. Bigia grossa. $H$. Dalos poszáta.

Ortolan. L. Emberiza hortulana. F. Ortolan. G. Gartenammer. $I$. Ortolano. $H$. Kerti sármány.

Osprey. L. Pandion haliaëtos. $F$. Balbusard. G. Fischadler. I. Falco. pescatore. $H$. Ráró.

Ostrich $L$. Struthio camelus. $F$. Autruche. G. Strauss. I. Struzzo. $H$. Strucz. 
Ousel, Ringed, v. Ringed Ousel. Ow1. L. Strix. F. Hibou. G. Eule. I. Gufo. $H$. Bagoly.

Oowl, Barn, v. Barn Owl. Owl, Eagle, v. Eagle Owl.

Owl, Fern, v. Nightjar.

Owl, Hawk, v. Hawk Owl.

COwl, Listle, v. Little Owl.

Owl, Long-eared, v. Long-eared Owl.

Owl, Pigmy, v. Pigmy Owl.

OWl, Scops, v. Scops Owl.

Owl, Short-eared, v. Short-eared Owl.

Owl, Snowy, v. Snowy Owl.

Owl, Tawny, v. Tawny Owl.

Oowl, Tengmalmi, v. TengmalmOwl.

Ow1, Ural, v. Ural Owl.

Oystercatcher. $L$. Haematopus ostralegus. $F$. Huitrier pie. $G$. Austernfischer. I. Beccaccia di mare. $H$. Osztrigamadár, Csiganyitogató.

Pallas's Sand-Grouse. $L$. Syrrhaptes paradoxus Pall. - ? - $G$. Fausthuhn. I. Siratte. $H$. Talpastyúk.

Pallid Harrier. L. Circus macrurus $\mathrm{Gm}$. $F$. Busard pâle. G. Steppenweihe. I. Albanella pallida. $H$. Fakó réthéja.

Partridge. $L$. Perdix perdix. $F$. Perdrix grise. G. Rephuhn. $I$. Starna. $H$. Fogoly.

Partridge, Greek, v. Greek Partridge.

OPeewit, v. Lapwing.

Pelican, Roseate, v. Roseate Pelican.

OPenduline Titmouse. $L$. Remiza pendulina. $F$. Remize penduline. G. Beutelmeise. I. Pendolino. H. Függö czinke.

Peregrine Falcon. $L$. Falco Peregrinus Tunst. $F$. Faucon pèle- rin. $G$. Wanderfalke $I$. Falcone. $H$. Vándorsólyom.

Petrel, v. Stormy Petrel.

Petrel, Stormy, v. Stormy Petrel.

Phaeton. L. Phaëton aethereus. $-?-G$. Tropikvogel. $-?-H$. Kerengö.

Phalarope, Grey, v. Grey Phalarope.

Phalarope, Red-necked, v. Rednecked Phalarope.

Pheasant. $I$. Phasianus colchicus. $F$. Faisan. G. Fasan. I. Fagiano. H. Fáczán.

OPied Flycatcher. L. Muscicapa atracapilla. $F$. Gobe-mouche. $G$. Trauerfliegenfänger. $I$. Balia nera. $H$. Kormos légykapó.

OPied Woodpecker. $L$. Dendrocopus maior. $F$. Pic épièche. $G$. Grosser Buntspecht. I. Picchio rosso maggiore. $H$. Nagy fakopáncs.

Pigeon, Wood, v. Ring-Dove.

Pigmy Crake. $L$. Ortygometra pusilla Pall. $F$. Poule d'eau pygmée. G. Zwerg-Sumpfhuhn. I. Schiribilla. $H$. Törpe vizicsibe.

Pigmy Curlew. $L$. Tringa subarquata. $F$. Bécasseau cocorli. $G$. Bogenschnäbliger Strandläufer. $I$. Piovanello. $H$. Sarlós partfutó. OPigmy Owl. $L$. Glaucidium passerinum. $F$. Chevêchette. $G$. Sperlingskauz. $I$. Civetta minore. $H$. Törpe kuvik.

Pine Grosbeak. $L$. Corythus enucleator. $F$. Durbec. G. Hackengimpel. $I$. Ciuffolotto delle pinete. $H$. Kampóscsörủ süvöltö.

Pintail. $L$. Dafila acuta. $F$. Pilet. $G$. Spiessente. I. Codone. $H$. Nyilas rucza.

OPipit, Red-throated, v. Redthroated Pipit.

OPipit, Tawny, v. Tawny Pipit. 
OPipit, Tree, v. Tree Pipit. OPipit, Water, v. Water Pipit. Plover. L. Charadrius. F. Pluvier. $G$. Regenpfeifer. $I$. Corriere. $H$. Lile.

OPlover, Golden, v. Golden Plover. OPlover, Grey, v. Grey Plover. OPlover, Kentish, v. Kentish Plo. ver.

Plover, Little Ringed, v. Little Ringed Plover.

OPlover, Ringed, v. Ringed Plover. Ploverspage, v. Ringed Plover.

Pochard. $L$. Fuligula ferina. $F$. Milouin. G. Tafelente. I. Moriglione. $H$. Barátrucza.

Pochard. L. Fuligula rufina Pall. $F$. Canard siffleur huppé. $G$. Kolbenente. $I$. Fistione turco. $H$ Üstökös rucza.

Pomatorhine Skua. $L$. Stercorarius-pomatorhinus Temm. $\boldsymbol{F}$. Labbe Pomarin. G. Mittlere Raubmöve. I. Stercorario mezzano. $H$. Szélesfarkú halfarkas.

Pratincole. $L$. Glareola pratincola. $F$. Perdrix de mer. $G$. HalsbandGiarol. $I$. Pernice di mare. $H$. Széki csér.

Ptarmigan, Alpine, v. Alpine Ptarmigan.

Puffin. L. Fratercula arctica. - ?$G$. Lunde. $I$. Polcinella di mare. $H$. Bárdorrú. Késes lunda.

Puffin, v. Shearwater.

Purple Gallinule. L. Porphyrio cocruleus Vand. - ?- G. Purpurhuhn. I. Pollo sultano. $H$. Bibor vizityúk.

Purple Heron. $L$. Ardea purpurea. $F$. Héron pourpré. G. PurpurReiher. $I$. Airone rosso $H$. Vörösgém.

Purple Sandpiper. $L$. Tringa maritima Brün. $F$. Bécasseau violet. G. See-Strandläufer. I. Piova- nello violetto. $H$. Tengeri partfutó.

Purre, v. Dunlin.

Quail. L. Coturnix coturnix. $k$. Caille. G. Wachtel. I. Quaglia. $H$. Fürj.

Quail, American, v. American Q. Rail, Water, v. Water Rail.

Raven. L. Corvus corax. $F$. Corbeau. G. Rabe. I. Corvo. H. Holló.

Razorbill. $L$. Alca torda. F. Pingouin macroptère. $G$. Tordalk. I. Gazza marina. $H$. Alka.

Red-backed Shrike. L. Lanius collurio. F. Pie-grièche écorcheur. $G$. Dorndreher. I. Averla piccola. $H$. Tövisszúró gébics.

ORedbreast. L. Erithacus rubecula. $F$. Gorge rouge. $G$. Rotkehlchen. I. Pettirosso. H. Vörösbegy.

ORed-breasted Flycatcher. $L$. Muscicapa parva Bechst. F. Gobemouche rougeâtre. $G$. Kleiner Fliegenfänger. I. Pigliamosche pettirosso. $H$. Kis légykapó.

ORed-legged Falcon. $L$. Cerchneis vespertinus. $F$. Faucon de soir. G. Rotfussfalk. I. Falco cuculo. $H$. Kékvércse.

Red-necked Grebe. L. Podiceps griseigena Bodd. $F$. Grébe jougris. $G$. Rothals-Lappentaucher. $I$. Svasso dal collo rosso. $H$. Pofás vöcsök.

Red-necked Phalarope. $L$. Phalaropus hyperboreus. $\boldsymbol{F}$. Phalarope cendré. $G$. Schmalschnäbliger Wassertreter. I. Phalaropo a becco sottile. $H$. Víztaposó.

ORedpoll, Mealy, v. Mealy Redpoll.

Redshank. L. Totanus calidris. F Chevalier Gambetta. G. Rotfuss-Strandläufer. $I$. Pettegola. $H$. Vöröslábú czankó. 
Redshank, Spotted, v. Spotted Redshank.

ORed-spotted Bluethroat. L.Cyanecula suecica. $F$. Gorge bleue. G. Blaukehlchen. I. Pet'azzuro orientale. $H$. Kékbegy.

ORedstart, Black, v. Black Redstart.

ORedstart, Garden, v. Garden Redstart.

Red-throated Pipit. L. Anthus cervinus Pall. - ? - G. Rotkehliger Pieper. I. Pispola gola rossa. $H$. Rőttorkú pipis.

ORedwing. $L$. Turdus iliacus. $F$. Mauvis. G. Rotdrossel. I. Tordo sassello. $H$. Szőlőrigó.

CReed Bunting. $L$ Emberiza schoeniclus. $F$. Bruant des roseaux. G. Rohrammer. I. Migliarino di padule. $H$. Nádi sármány.

OReedling, Bearded, v. Bearded Reedling.

Reed Warbler. $L$. Acrocephalus streperus Viell. $F$. Rousserolle effarvatte. G. Teichsänger. I. Cannaiola. $H$. Cserregő poszáta.

Reeve. $L$. Pavoncella pugnax. $F$. Combattant. G. Kampfstrandläufer. $I$. Combattente. $H$. Pajzsos czankó.

Ring-Dove. $L$. Columba palumbus. $F$. Colombe Ramier. G. Ringeltaube. $I$. Colombaccio. $H$. Székács.

Ringed Ousel. $L$. Turdus torquatus. $F$. Merle à plastron. $G$. Ringamsel. I. Merlo dal collare. $H$. Örvös rigó.

ORinged Plover. $L$. Charadrius hiaticola. F. Pluvier à collier. $G$. Halsband-Regenpfeifer. I. Corriere Grosso. $H$. Juhászka, Parti lile.

ORiver Warbler. $L$. Locustella fluviatilis Wolf. $F$. Becfin riverain. G. Fluss-Schwirl. I. Salciaiola. $H$. Berki tücsökmadár.

Rock Dove. L. Columba livia. $F$. Colombe biset. G. Felsentaube. $I$. Picchione selvatico. $H$. Vadgalamb.

ORock Thrush. $L$. Monticola saxatilis. $F$. Merle de roche $G$. Steindrossel. $I$. Codirossone. H. Kövi rigó.

ORoller. $L$. Coracias garrula. $F$. Rollier. G.Mandelkrähe.I. Ghiandaia marina. $H$. Szalakóta.

Rook. $L$. Corvus frugilegus $F$. Corbeau Freux. $G$. Saatkrähe. I. Corvo. $H$. Vetési varjú.

Roseate Pelican. L. Pelecanus onocrotalus. F. Pélican blanc. $G$. Kropfgans. I. Pellicano. $H$. Gödény.

ORose-coloured Starling. L.Pastor roseus. $F$. Martin roselin. G. Rosenstaar. I. Storno roseo. H. Pásztormadár.

Rose-finch, Caucasian, v. Caucasian Rose-fincl.

Rough-legged Buzzard. L. Archibuteo lagopus. $F$. Buse pattue. G. Rauhfuss-Bussard. I. Pojana calzata. $H$. Gatyás ölyv.

Ruby-throat. $L$. Calliope. $F$. Calliope. (t. Calliope. I. Calliope. $H$. Kalliope.

Ruddy Sheldrake. L. Tadorna casarca. $F$. Tadorne casarca. $G$. Rostente. - ? - H. Vörös ásólúd.

Ruff, v. Reeve.

Saker. $L$. Falco laniarius. F. Faucon sacré. $G$. Würgfalke. $I$. Lanario. $H$. Kerecsen sólyom.

Sanderling. $L$. Calidris arenaria Illig. $F$. Sanderling variable. $G$. Ufer-Sanderling. I. Pionvanello tridattilo. $H$. Fenyérfutó. 
Sand-Grouse, Black-bellied, v. Black-bellied Sand-Grouse.

Sand-Grouse, Pallas's, v. Pallas's Sand-Grouse.

Sand Martin. $L$. Clivicola riparia. $F$. Hirondelle de rivage. $G$ Uferschwalbe. I. Topino. $H$. Parti fecske.

Sandpiper. $L$. Totanus. $F$. Chevalier. Gr. Wasserläufer. $I$. Piropiro. H. Czankó.

Sandpiper, Green, v. Green Sandpiper.

Sandpiper, Marsh,v. Marsh Sandpiper.

Sandpiper, Purple, v. Purple Sandpiper.

Sandpiper, Wood, v. Wood Sandpiper.

Savi's Warbler, v. Warbler Savi's.

Scaup, Scaup Duck. L. Fuligula marila. $F$. Canard miloninau. $G$. Bergente. $I$. Moretta grigia. $H$. Hegyi rucza.

OScops Owl. L. Pisorhina Scops. F. Petit Duc. G. Zwergohreule. I. Assiole. 'H. Füles kuvik.

Scoter, Black, v. Black Scoter.

Scoter, Velvet, v. Velvet Scoter.

Sea Eagle. $L$. Haliaëtus albicilla. $F$. Pygargue à queue blanche. $G$. Seeadler. $I$. Aquila di mare. $H$. Réti sas.

Seamew. $L$. Larus $F$. Goëland. $G$. Seemöve. $I$. Gabbiano. $H$ Sirály.

OSedge Warbler. L. Calamodus schoenobaenus. F. Becfin phragmite. $G$. Schilf-Rohrsänger. $I$. Forapaglie. $H$. Foltos sitke.

Serin-Finch. $L$. Serinus serinus. $F$. Serin. G. Girlitz. I. Vercellino. H. Csicsörke.

Shearwater; Manx. L. Puffinus anglorum. $F$. Pétrel Manks. $G$. Nordischer Tauchersturmvogel.
I. Berta minore. $\boldsymbol{h}$. Vészmadár, Angol vészmadár.

Sheldrake, Ruddy, v. Ruddy Sheldrake.

Shore-Lark. L. Otocoris alpestris. $F$. Alouette alpine. $G$. Berglerche. I. Lodola gola gialla. $H$. Füles pacsirta, Havasi füles pacsirta.

CShort-eared 0w1. L. Asio accipitrinus Pall. $F$. Duc à courtes oreilles. G. Sumpfohreule. I. Gufo di padule. $H$. Réti bagoly.

Short-toed Eagle. $L$. Circaëtus gallicus. $F$. Aigle Jean le blanc. $G$. Schlangenadler. I. Biancone. $H$. Kigyászölyv.

Shoveller. L. Spatula clypeata. $F$. Souchet. $G$. Löffelente. $I$. Mestolone. $H$. Kanalas rucza.

Shrike. $L$. Lanius. $F$. Pie grièche. $G$. Würger. $I$. Averla. $H$. Gébics.

Shrike, Great Grey, v. Great Grey Shrike.

Shrike, Lesser Grey. I. Lanius minor Gmel. $F$. Pie Grièche d'Italie. $G$. Schwartzstirniger Würger. $I$. Averla cenerina. $H$. Kis örgébics.

Shrike, Red-backed, v. Red-backed Shrike.

Single Snipe. $L$. Gallinago gallinago. F. Chèvre volante. G. Moorschnepfe. I. Beccaccino. H. Sárszalonka.

OSiskin. L. Chrysomitris spinus. $F$. Tarin. G. Zeisig. I. Lucarino. H. Csiz.

Skua, v. Great Skua.

Skua, Arctic, v. Arctic Skua.

Skua, Buffon, v. Buffon Skua

Skua, Great, v. Great Skua.

Skua, Pomatorhine, v. Pomatorhine Skua.

OSkylark. $L$. Alaude arvensis. $F$. Alouette de champs. $G$. Lerche. $I$. Lodola. $H$. Mezei pacsirta. 
Slender-billed Curiew. $L$. Numenius tenuirostris. $F$. Courlis a bec grèle. $G$. Dünnschnäbliger Sichler. $I$. Chiurlotello. $H$. Vékonycsőrủ póling.

Smew. L. Mergus albellus. $F$. Petit Harle huppé. $G$. Kleiner Säger. I. Pesciaiola. H. Kis muszkabuvár.

Snipe, Double, v. Double Snipe. Snipe, Jack, v. Jack Snipe.

Snipe, Single, v. Single Snipe.

Snow Bunting. $L$. Calcarius nivalis. $F$. Ortolan de neige. $G$. Schneespornammer. $I$. Zigolo della neve. $H$. Hósármány.

Snowy Owl. $L$. Nyctea nivea. $F$. Surnie Harfang. G. Sclinee-Eule. I. Arfango. $H$ Hóbagoly.

OSombre Titmouse. $L$. Parus lugubris Temm. $F$. Mésange triste. $G$. Trauermeise. $I$. Cincia dalmatina. $H$. Gyászos czinege.

Song Thrush. $L$. Turdus musicus. $F$. Grive. $G$. Singdrossel. $I$. Tordo. $H$. Énekes rigó.

Sparrow. $L$. Passer domesticus. $F$. Moineau. $G$. Haussperling $I$. Passera oltramontana. $H$. Háziveréb, Veréb.

Sparrow-Hawk. $L$. Accipiter nisus. F. Épervier. G' Sperber. I. Sparvier. $H$. Karvaly.

Sparrow, Italian, v. Italian Sparrow.

Sparrow, Tree, v. Tree Sparrow. Spoonbill. $L$. Platalea leucorodia. $F$. Spatule blanche. $G$. Löffelreiher, Löffelgans. $I$. Spatola. $H$. Kanalas gém.

Spotted Crake. $L$. Ortygometra porzana. $F$. Poule d'eau maruette. $G$. Punktiertes Rohrhuhn. I. Voltolino. H. Pettyes vizicsibe.

OSpotted Flycatcher. L. Muscicapa grisola. $F$. Gobe-mouche.
G. Grauer Fliegenfänger. I. Pigliamosche. $H$. Szürke légykapó.

Spotted Redshank. $L$. Totanus fuscus. $F$. Chevalier brun. $G$. Dunkler Wasserläufer. I. Totano moro. $H$. Füstös czankó.

Squacco. $L$. Ardea ralloides. $F$. Héron crabier. $G$. Rallenreiher. I. Sgarza ciuffetto. $H$. Üstökös gém.

OStarling. $L$. Sturnus vulgaris. $F$. Étourneau. G. Staar. I. Storno. $H$. Seregély.

OStarling, Rose-coloured, v. Rosecoloured Starling.

Stilt, Black-winged, v. Black-winged Stilt.

Stint, Temminck, v. Temminck Stint.

Stock Dove. L. Columba oenas. F. Colombe. $G$. Hohltaube. $I$. Colombella. $H$. Kék galamb.

CStonechat. L. Pratincola rubicola. $F$. Tarier rubicole. G. Schwarzkehlchen. I. Saltinpalo. H. Czigány csaláncsúcs.

Stone Curlew, v. Tickknee.

OStork. L. Ciconia. F. Cigogne. $G$. Storch. I. Cicogna. H. Gólya.

OStork, Black, v. Black Stork.

OStork, White, v. White Stork.

Stormy Petrel. $L$. Thalassidroma pelagica. $F$. Thalassidroma tempête. $G$. Schwalben-Sturmvogel. I. Uccello delle tempeste. $H$. Viharfecske.

Summer Snipe. L. Totanus hypoleucos. $F$. Chevalier guignette. $G$. Fluss-Uferläufer. I. Piro-piro piccolo. II. Billegetỏ czankó.

Snipe, [Summer], v. Summer Snipe. OStint, [Little], v. Little Stint.

OSwallow. $L$. Hirundo. $F$. Hirondelle. $G$. Schwalbe. $I$. Rondine. H. Fecske

OSwallow. $L$. Hirundo rustica. $F$. Hirondelle de cheminée. G. Rauch- 
schwalbe. $I$. Rondine. $H$. Füsti fecske.

Swan. $L$. Cygnus. $F$. Cygne. $G$. Schwan. I. Cigno selvatico. $H$. Hattyú.

Swan, Whooper, v. Wild Swan.

Swan, Wild, v. Wild Swan.

OSwift. $L$. Cypselus apus. $F$. Martinet. G. Mauerschwalbe. I. Rondone. H. Kazári fecske, Sarlós fecske.

Swift, Alpine, v. Alpine Swift.

Tawny Ow1. $L$. Syrninus aluco. $F$. Chouette hulotte. $G$. Waldkauz. I. Gufo selvatico. H. Macskabagoly.

Tawny Pipit. $L$. Anthus campestris. $F$. Pipit roussoline. $G$. Brachpieper. I. Calandro. H. Parlagi pipis.

Teal. $L$. Querquedula crecca. $F$. Sarcelle d'hiver. $G$. Krickente. $I$. Alzavola. H. Apró rucza.

Teal, Falcated, v. Falcated Teal.

Temminck Stint. $L$. Tringa Temminckii Leisl. $F$. Bécasseau Temminck. G. Temmincks Strandläufer. $I$. Gambecchio nano. $H$. Temminck partfutó.

CTengmalmi Owl. $L$. Nyctale Tengmalmi Gm. $F$. TengmalmChevêche. G. Tengmalms Kautz. I. Civetta capogrosso. $H$. Gatyás csuvik.

Tern. L. Sterna. F. Hirondelle de mer. G. Seeschwalbe. I. Rondine di mare. $H$. Halászka.

OTern, Black, v. Black Tern.

Tern, Caspian, v. Caspian Tern.

Tern, Common, v. Common Tern.

Tern, Little, v. Little Tern.

Tern, Nile, v. Nile Tern.

Tern, Whiskered, v. Whiskered Tern.

OTern, White-winged Black, v. White-winged Black Tern.
Thickknee. $L$. Oedicnemus crepitans. $F$. Oedicnème. $G$. Dickfuss. I. Occhione. $H$. Ugartyúk.

OThree-toed Woodpecker. $L$. Picoides tridactylus. $F$. Picoide tridactyle. G. Dreizehiger Specht. I. Picchio tridattilo. H. Háromujjú höcsik, Höcsik.

Thrush. $L$. Turdus. $F$. Grive. $G$. Drossel. I. Tordo. H. Rigó.

CThrush, Blue, v. Blue Thrush.

OThrush, Mistletoe, v. Mistletoe Thrush.

Thrush Nightingale. $L$. Luscinia philomela Bechst. $F$. Rossignol de Hongrie. $G$ Ungarische Nachtigall. $I$. Rusignolo maggiore. $H$. Magyar fülemüle.

OThrush, Rock, v. Rock Thrush. OThrush, Song, v. Song Thrush. OTitlark. $L$. Anthus pratensis. $F$. Pipi des prés. $G$. Wiesenpieper. I. Pispola. $H$. Réti pipis.

Titmouse. $L$. Parus. $F$. Mésange. $G$. Meise. I. Cincia. H. Czinege.

OTitmouse, Azure, v. Azure Titmouse.

OTitmouse, Blue, v. Blue Titmouse.

CTitmouse, Coal, v. Coal Titmouse.

Titmouse, Crested, v. Crested Titmouse.

OTitmouse, Great, v. Great Titmouse.

OTitmouse, Marsh, v. Marsh Titmouse.

CTitmouse, Longtailed, v. Longtailed Titmouse.

CTitmouse, Penduline, v. Penduline Titmouse.

OTitmouse, Sombre, v. Sombre Titmouse.

CTree Creeper. $L$. Certhia familiaris. - ?-G. Baumläufer. I.Ramlpicchino. $H$. Fakúsz, Famászó. 
OTree Pipit. L. Anthus trivialis. $F$. Pipit des arbres. G. Baumpieper. I. Prispolone. $H$. Erdei pipis.

Tree Sparrow. L. Passer montanus. $F$. Moineau friquet. $G$. Feldsperling $I$. Passera mattugia. $H$. Mezei veréb.

Tufted Duck. L. Fuligula cristata. $F$. Morillon. G. Schopfente. I. Moretta. $H$. Kontyos rucza.

Turnstone. $L$. Strepsilas interpres. $F$. Tournepierre. G. Steinwälzer. I. Voltapietre. $H$. Kőforgató.

Turtle-dove. $L$. Turtur turtur. $F$. Tourterelle. $G$. Turteltaube. $I$. Tortora. $H$. Gerle.

Two-barred Crossbill. L. Loxia bifasciata Brehm. $F$. Bec-croisé bifascié. $G$. Weissbindiger Kreuzschnabel. 1. Crociere fasciato. $H$. Szalagos keresztcsőrü.

Tystey. $L$. Uria grylle. $F$. Guillemot grylle. G. Gryll-Teiste. $I$. Uria grylle. $H$. Fekete lumma.

Ural Owl. $L$. Syrnium uralense. -?- G. Ural-Habichtseule. I. Gufo degli Urali. H. Urali bagoly.

Velvet Scoter. $L$. Oidemia fusca. $F$. Grande Macreuse. $G$. Sammetente. $I$. Orco marino. $H$. Füstös rucza.

Vulture. $L$. Vultur. $F$. Vautour. G. Geier. I. Avvoltoio. H. Keselyü.

Vulture, Bearded, v. Bearded Vulture.

Vulture, Black, v. Black Vulture. Vulture, Egyptian, v. Egyptian Vulture.

Vulture, Griffon, v. Griffon Vulture. Wagtail. L. Motacilla. F. Lavandière. $G$. Bachstelze. $I$. Ballerina. $H$. Billegető.

OWagtail, Black-headed,v. Blackheaded Wagtail.
Wagtail, Blue-headed, v. Blueheaded Wagtail.

Wagtail, Grey, v. Grey Wagtail. OWagtail, White, v. White Wagtail.

Wagtail, Yellow, v. Yellow Wagtail.

Wall Creeper. L. Tichodroma muraria. $F$. Tichodrome èchelette. G. Mauerläufer. I. Picchio muraiolo. $H$. Hajnalmadár.

OWarbler. $L$. Sylvia. $F$. Fauvette. $G$. Grasmücke. I. Beccafico. $H$. Poszáta.

OWarbler, Barred, v. Barred Warbler.

OWarbler, Bonelli's, v. Bonelli's Warbler.

Warbler, Garden, v. Garden Warbler.

OWarbler, Grasshopper, v. Grasshopper Warbler.

Warbler, Great Red, v. Great Red Warbler.

Warbler, Icterine, v. Icterine Warbler.

OWarbler, Marsh, v. Marsh Warbler.

OWarbler, Orphean, v. Orphean Warbler.

Warbler, Reed, v. Reed Warbler. Warbler, River, v. River Warbler. OWarbler Savi's. L. Locustella luscinioides Savi. $F$. Fauvette des Saules. G. Weiden-Schwirl. I. Salciaiola. $H$. Nádi tücsökmadár.

OWarbler, Sedge, v. Sedge Warbler.

Water Pipit. L. Anthus spipoletta.F.Pipit spioncelle.G.Wasserpieper. $I$. Spioncello. $H$. Havasi pipis.

Water Rail. $L$. Rallus aquaticus. $F$. Râle d'eau. $G$. Wasserralle. I. Porciglione. $H$. Viziguvat. 
Waxwing. $L$. Ampelis garrula. $F$. Jaseur de Bohême. G. Seidenschwanz. $I$. Becco frusone. $H$. Csonttollú madár.

Whaup, v. Curlew.

Wheatear. $L$. Saxicola oenanthe. $F$. Motteux-cul-blanc. Gr. Steinschmätzer. $I$. Cul bianco. $H$. Hantmadár.

Whimbrel. $L$. Numenius phaeopus. $F$. Courlieu. G. Regenbrachvogel. I. Chiurlo piccolo. H. Esöpóling.

Whinchat. L. Pratincola rubetra. $F$. Tarier. G. Wiesenschmätzer. 1. Stiaccino. $H$. Rozsdás csaláncsúcs.

Whiskered Tern. L. Hydrochelidon hybrida Pall. $F$. Hirondelle de mer moustache. $G$. Weissbärtige Seeschwalbe. $I$. Rondine di - mare piombata. $H$. Fattyúszerkő.

White-backed Woodpecker. $L$. Dendrocopus leuconotus Bechst. -?-G. Weissrückiger Specht. I. Picchio a dorso bianco. $H$. Fehérhátú fakopáncs

White-collared Flycatcher. $L$. Muscicapa collaris Bechst. $F$. Gobe-mouche à collier. G. Halsband-Fliegenfänger. $I$. Balia dal collare, $H$. Örvös légykapó.

White-eyed Duck. $L$. Nyroca leucophthalmos. $F$. Fuligule nyroca. G. Moorente. I. Moretta tabaccata. $H$. Czigányrucza.

White-fronted Goose. $L$. Anser albifrons Scop. $F$. Oie rieuse. $G$. Blässgans. I. Oca lombardella. $H$. Lilik.

White-headed Duck. $L$. Erismatura leucocephala Scop. $F$. Canard couronné. $G$. Ruderente. $I$. Gobbo rugginoso. $H$. Kékcsörü récze.
White Stork. L. Ciconia alba. $F$. Cigogne. G. Weisser Storch. $I$. Ciconia. $H$. Fehér gólya.

Whitethroat. $L$. Sylvia sylvia. $F$. Fauvette grise. $G$. Dorngrasmücke. $I$. Sterpazzola. H. Mezei poszáta.

Whitethroat, Lesser, v. Lesser Whitethroat.

White Wagtail. L.Motacilla alba. $F$. Lavandière. $G$. Weisse Bachstelze. $I$. Ballerina. $H$. Barázdabillegetö.

White-winged Black Tern. $L$. Hydrochelidon leucoptera $M$. et Sch. $F$. Hirondelle de mer leucoptère. G. Weissflügelige Seeschwalbe. I. Mignattino ali bianche. $\boldsymbol{H}$. Fehérszárnyú szerkő.

White-winged Lark. $L$. Alauda sibirica Gm. F. Alouette de Sibérie. $G$. Weissflügelige Lerche. $I$. Lodola siberiana. $H$. Fehérszárnyú pacsirta.

Widgeon. L. Mareca penelope. $F$. Canard siffleur. G. Pfeifente. $I$. Fiscione. $H$. Fütyülö rucza.

Wild Duck. $L$. Anas boschas. $F$. Canard sauvage. G. Stockente. I. Germano reale. $H$. Tökés rucza.

Wild Swan. L. Cygnus-musicus Bechst. $F$. Cygne sauvage. $G$. Singschwan. - ? - H. Vadhattyú. Willock, v. Guillemot.

OWillow Wren. $L$. Phylloscopus trochilus. F. Pouillot-fitis. G. Fitis Laubvogel. I. Lui grosso. H. Fitisz fủzike, Fitiszmadár.

Woodchat. $L$. Lanius sonator. $F$. Pie-Grièche rousse. G. RotkopfWürger. I. Averla capirossá. $H$. Vörösfejủ gébics.

Woodcock. $L$. Scolopax rusticola. $F$. Bécasse. G. Waldschnepfe.

I. Beccaccia. $H$. Szalonka. 
OWood Lark. L. Lin. Alauda arborea. $F$. Aluette Lulu. G. Waldlerche. $I$. Totta villa. $H$. Erdei pacsirta.

OWoodpecker. L. Picus. F. Pic. $G$. Specht. I. Picchio. H. Har. kály.

OWoodpecker, Barred, v. Barred Woodpecker.

Woodpecker, Black, v. Black Woodpecker.

OWoodpecker, Green, v. Green Woodpecker.

Woodpecker, Grey-headed, v. Grey-headed Woodpecker.

OWoodpecker, Middle Spotted, v. Middle Spotted Woodpecker.

OWoodpecker, Pied, v. Pied Woodpecker.

Woodpecker, Three-toed, v. Three-toed Woodpecker.

OWoodpecker, White-backed, v. White-backed Woodpecker.

Wood Pigeon, v. Ring-Dove.

Wood Sandpiper. $L$. Totanus glareola. $F$. Chevalier sylvain. $G$.
Bruch-Wasserläufer. I. Piro-piro boschereccio. H. Réti czankó.

OWood-Wren. L. Phylloscopus sibilator Bechst. F. Pouillot siffleur. $G$. Waldlaubvogel. I. Lui verde. $H$. Sisegö füzike.

OWren. $L$ Troglotydes. $F$. Trog. lodites. G. Zaunkönig. I. Scricciolo. $H$. Ökörszem.

OWren, Fire-crested, v. Firecrested Wren.

OWren, Golden-crested, v. Golden-crested Wren.

OWren, Willow, v. Willow Wren. OWren, Wood, v Wood Wren.

OWryneck. $L$. Yunx torquilla. $k$. Torcol. G. Wendehals. I. Torcicollo. $H$. Nyaktekercs.

Yellowhammer. L. Emberiza citrinella $L$. Bruant jaune. G. Goldammer. I. Zigolo giallo. $H$. Czitromsármány.

Yellow Wagtail. L. Motacilla campestris. F. Bergeronette jaune. $G$. Schafstelze. I. Cutrettola testa gialla. $H$. Mezei billegetö. 


\section{DOCUMENTS.}





\title{
Documents.
}

\section{Original Text of the „Declaration" of 1875.}

\author{
D É C L A R A T I O N.
}

Le Gouvernement de Sa Majesté le Roi d'Italie et celui de Sả Majesté Impériale et Royale Apostolique, animés du désir d'assurer une protection générale et efficace aux oiseaux utiles à l'agriculture, sont convenus des dispositions suivantes:

\section{Article I.}

Les Gouvernements des deux Parties contractantes s'engagent à prendre, par voie de législation, des mesures aptes à assurer aux oiseaux utiles à l'agriculture la protection la plus étendue, au moins dans les limites des articles suivants II. à V.

\section{Article 11 .}

Il sera généralement défendu de détruire ou d'enlever les nids et places à couvées, de prendre les oeufs et de capturer d'une manière quelconque les petits oiseaux.

De même sera généralement interdite la vente des nids, oeufs et oiseaux pris contre cette défense.

Article III.

Il sera, en outre, généralement défendu:

a) de prendre ou de tuer les oiseaux pendant la nuit au moyen 
de glu, lacets et filets, armes à feu ou autres; le temps de la nuit étant calculé à partir d'une heure après le coucher du soleil jusqu'à une heure avant son lever;

b) de prendre ou de tuer les oiseaux d'une manière quelconque tant que le sol sera couvert de neige;

c) de les prendre ou de les tuer d'une manière quelconque le long des rigoles, près des sources et des étangs durant la sécheresse;

d) de prendre les oiseaux au moyen de grains ou autres aliments mêlés de substances narcotiques ou vénéneuses;

$e$ ) de prendre les oiseaux au moyen de lacets et pièges d'espèce et de forme quelconque, placés sur le sol; notamment au moyen de nasses, petites cages, archets, des attrapes nommées plocke en Dalmatie, ainsi que des lanciatora en usage pour la capture des alouettes;

$f$ ) de prendre les oiseaux à l'aide des filets nommés paretelle et en général à l'aide de tous filets mobiles et transportables tendus sur le sol ou à travers du champ, dans les broussailles ou sur le chemin.

Les Gouvernements des deux Parties contractantes se réservent d'interdire d'autres manières de capturer les oiseaux s'il vient à ressortir des rapports des autorités compétentes d'Autriche-Hongrie ou de ceux des Conseils provinciaux d'Italie que ces manières de capturer les oiseaux sont trop déstructives et nuisibles au maintien des oiseaux du pays ou de passage.

\section{Article IV.}

Du reste outre les défenses générales formulées aux articles II et III, il ne peut être permis de prendre ou de tuer les oiseaux d'une manière quelconque que:

a) depuis le 1-er septembre jusqu'à la fin de février au moyen d'armes à feu ;

b) depuis le 15. septembre jusqu'à la fin de février à l'aide d'autres moyens non prohibés.

La vente des oiseaux doit être interdite hors de ces époques.

Article V.

Toutefois chaque Gouvernement peut sous certaines conditions et sur demande motivée, accorder des exceptions aux dispositions des Art. II, III et IV en faveur des buts scientifiques. 


\section{Article VI.}

Comme, dans l'esprit de l'article I-er, les dispositions de cette déclaration n'ont pour but que la protection des espèces d'oiseaux utiles à l'agriculture, il va sans dire que les articles II-V ne s'appliquent ni aux oiseaux de proie ou aux oiseaux quelconques reconnus nousibles à l'économie rurale ou domestique, ni à la volaille entretenue dans l'une ou l'autre. Bien que les articles II-V ne soient pas absolument applicables aux espèces d'oiseaux qui, sans être décidément utiles ou nuisibles à l'agriculture, n'en ont pas moins une certaine valeur, surtout comme objet de chasse; les Gouvernements respectifs se déclarent pourtant disposés à prendre les mesures propres à assurer la conservation de ces espèces comme objet de chasse.

\section{Article VII.}

Les Gouvernements respectifs se communiqueront, le cas échéant, les mesures protectrices des oiseaux prises dans leurs États, ainsi que les explications utiles ou désirables.

\section{Article VIII.}

Les Gouvernements des deux Parties contractantes tâcheront d'obenir l'adhésion d'autres États à cette déclaration.

\section{Article IX.}

La présente déclaration sera délivrée en deux exemplaires conformes à signer par les Ministres respectifs des affaires étrangères et à échanger entre eux.

Sur quoi le soussigné Ministre des affaires étrangères de Sa Majesté le Roi d'Italie a signé la présente déclaration et y a fait apposer le sceau du Ministère des affaires étrangères.

Fait à Rome, le vingt-neuf novembre mil huit cent soixante-quinze.

$$
\text { L. S. (signé) Visconti Venosta. }
$$




\section{Original Text of the Protocol annexed to the „Declaration" of 1875.}

\section{PROTO C O LE.}

Les Gouvernements de etc. ayant été invités par les Gouvernements d'Autriche-Hongrie et d'Italie à accéder aux dispositions arrêtées entre ces deux derniers pour assurer une protection efficace aux oiseaux utiles à l'agriculture, et s'étant déclarés prêts à répondre à cette invitation, les plénipotentiaires soussignés savoir: pour etc. .

se sont réunis aujourd'hui et se sont entendus sur la suivante déclaration pour les uns, et d'acceptation pour les autres.

$\S 1$. Les Gouvernements etc. accèdent à la déclaration concernant la protection des oiseaux utiles à l'agriculture, échangée entre l'AutricheHongrie et l'Italie et datée de Budapest le 5 et de Rome le 29. novembre 1875, laquelle déclaration est annexée au présent protocole dont elle fait partie intégrante; ils assument toutes les obligations et réclament tous les droits et avantages résultant pour les parties contractantes.

Ils se réservent pleine liberté de désigner dans leurs propres réglements, d'après les usages de leurs pays, les moyens de capture interdits (art. III) sans toutefois qu'aucun de ces moyens, relativement au but que se propose la dite déclaration, présente moins d'efficacité que ceux dont il est fait mention dans l'article III de la déclaration; ils se réservent aussi d'introduire, relativement au temps de la capture (art. IV), des mesures de protection plus rigoureuses encore que celles stipulées dans la déclaration.

$\S$ 2. Les Gouvernements d'Autriche-Hongrie et d'Italie acceptent cette déclaration d'adhésion ainsi que la réserve y jointe, et assurent en même temps aux Gouvernements accédants tous les droits et avantages que la dite déclaration garantit aux parties contractantes.

§. 3. Toutefois, comme il s'est élévé des doutes sur la portée de l'expression „petits oiseaux" employée à la fin de l'alinéa 1 de l'article II de la déclaration ci-jointe, il est constaté d'un commun accord que ce n'est pas la taille mais bien l'âge des oiseaux que la dit alinéa a en vue, et que par conséquent le mot petits doit être remplacé par le mot "jeunes".

En foi de quoi les soussignés ont, en vertu de leur pleins-pouvoirs, signé le présent protocole en -, expeditions et y ont apposé le sceau de leurs armes. - Fait à Vienne le etc. 


\section{Original Text of the International Convention for the Protection of Birds, Paris, 1902.}

\section{Convention}

pour la protection des oiseaux utiles à l'agriculture.

Sa Majesté l'Empereur d'Autriche, Roi de Bohême etc., et Roi Apostolique de Hongrie, agissant également au nom de Son Altesse le Prince de Liechtenstein; Sa Majesté l'Empereur d'Allemagne, Roi de Prusse, au nom de l'Empire Allemand; Sa Majesté le Roi des Belges, Sa Majesté le Roi d'Espagne et, en Son Nom, Sa Majesté la Reine Régente du Royaume; Le Président de la République Française; Sa Majesté le Roi des Hellènes; Son Altesse Royale le Grand Duc de Luxembourg; Son Altesse Sérénissime le Prince de Monaco; Sa Majesté le Roi de Portugal et des Algarves; Sa Majesté le Roi de Suède et de Norvège, au nom de la Suède, et le Conseil Fédéral Suisse, reconnaissant l'opportunité d'une action commune dans les différents pays pour la conservation des oiseaux utiles à l'agriculture, ont résolu de conclure une Convention à cet effet et ont nommé pour leurs Plénipotentiaires savoir :

Sa Majesté l'Empereur d'Autriche, Roi de Bohême etc., et Roi Apostolique de Hongrie,

S. Exc. le comte de Wolkenstein-Trostburg, Son Ambassadeur Extraordinaire et Plénipotentiaire près le Président de la République Française ;

Sa Majesté l'Empereur d'Allemagne, Roi de Prusse,

S. A. S. le Prince de Radolin, Son Ambassadeur Extraordinaire et Plénipotentiaire près le Président de la République Française;

Sa Majesté le Roi des Belges,

M. le Baron d'Anethan, Son Envoyé Extraordinaire et Ministre Plénipotentiaire près le Président de la République Française;

Sa Majesté le Roi d'Espagne et, en Son Nom, Sa Majesté la Reine Régente du Royaume,

S. Exc. M. de Leon y Castillo, Marquis del Muni, Son Ambassadeur Extraordinaire et Plénipotentiaire près le Président de la Répuqlique Française;

Herman: Conv. for the Prot. of Birds. 
Le Président de La République Française,

S. Exc. M. Théophile Delcassé, Député, Ministre des Affaires Étrangères ;

Sa Majesté le Roi des Hellènes,

M. N. Delyanni, Son Envoyé Extraordinaire et Ministre Plénipotentiaire près le Président de la République Française;

Son Altesse Royale le Grand-Duc de Luxembourg,

M. Vannerus, Charge d'Affaires de Luxembourg à Paris ;

Son Altesse Sérénissime le Prince de Monaco,

M. I. B. Depelley, Chargé d'Affaires de Monaco à Paris ;

Sa Majesté le Roi de Portugal et des Algarves,

M. T. De Souza Roza, Son Envoyé Extraordinaire et Ministre Plénipotentiaire près le Président de la République Française;

Sa Majesté le Roi de Suède et de Norvège, au nom de la Suède,

M. H. Åkermann, Son Envoyé Extraordinaire et Ministre Plénipotentiaire près le Président de la République Française;

Et le Conseil Fédéral Suisse,

M. Charles Lardy, Envoyé Extraordinaire et Ministre Plénipotentiaire de la Confédération Suisse près le Président de la République Française,

Lesquels, après s'être communiqué leurs pleins pouvoirs, trouvés en bonne et due forme, sont convenus des articles suivants:

Article Premier.

Les oiseaux utiles à l'agriculture, spécialement les insectivores et notamment les oiseaux énumérés dans la liste No 1 annexée à la présente Convention, laquelle sera susceptible d'additions par la législation de chaque pays, jouiront d'une protection absolue, de façon qu'il soit interdit de les tuer en tout temps et de quelque manière que ce soit, d'en détruire les nids, oeufs et couvées.

En attendant que ce résultat soit atteint partout, dans son ensemble, les Hautes Parties Contractantes s'engagent à prendre ou à proposer à leurs législatures respectives les dispositions nécessaires pour assurer l'exécution des mesures comprises dans les articles ci-après.

\section{Art. 2.}

Il sera défendu d'enlever les nids, de prendre les oeufs, de capturer et de détruire les couvées en tout temps et par des moyens quelconques. 
L'importation et le transit, le transport, le colportage, la mise en vente, la vente et l'achat de ces nids, oeufs et couvées, seront interdits.

Cette interdiction ne s'étendra pas à la destruction, par le pro. priétaire, usufruitier ou leur mandataire, des nids que des oiseaux auront construits dans ou contre les maisons d'habitation ou les batiments en général et dans l'intérieur des cours. Il pourra de plus être dérogé, à titre exceptionnel, aux dispositions du présent article, en ce qui concerne les oeufs de vanneau et de mouette.

Art. 3.

Seront prohibés la pose et l'emploi des pièges, cages, filets, lacets, gluaux, et de touts autres moyens quelconques ayant pour objet de faciliter la capture ou la destruction en masse des oiseaux.

Art. 4.

Dans le cas où les Hautes Parties Contractantes ne se trouveraient pas en mesure d'appliquer immédiatement et dans leur intégralité les dispositions prohibitives de l'article qui précède, Elles pouront apporter des atténuations jugées nécessaires auxdites prohibitions, mais Elles s'engagent à restreindre l'emploi des méthodes, engins et moyens de capture et de destruction, de façon à parvenir à réaliser peu à peu les mesures de protection mentionnées dans l'article 3.

\section{Art. 5.}

Outre les défenses générales formulées à l'article 3 , il est interdit de prendre ou de tuer, du 1-er mars au 15 septembre de chaque année, les oiseaux utiles énumérés dans la liste $N^{0} 1$, annexée à la Convention.

La vente et la mise en vente en seront interdites également pendant la même période.

Les Hautes Parties Contractantes s'engagent, dans la mesure où leur législation le permet, à prohiber l'entrée et le transit des dits oiseaux et leur transport du 1-er mars au 15 septembre.

La durée de l'interdiction prévue dans le présent article pourra, toutefois, être modifiée dans les pays septentrionaux.

Art. 6.

Les autorités compétentes pourront accorder exceptionnellement aux propriétaires ou exploitants de vignobles, vergers et jardins, de 
pépinières, de champs plantés ou ensemencés, ainsi qu'aux agents préposés à leur surveillance, le droit temporaire de tirer à l'arme à feu sur les oiseaux dont la présence serait nuisible et causerait un réel dommage.

Il restera toutefois interdit de mettre en vente et de vendre les oiseaux tués dans ces conditions.

\section{Art. 7.}

Des exceptions aux dispositions de cette Convention pourront être accordées dans un intérêt scientifique ou de repeuplement par les autorités compétentes, suivant les cas et en prenant toutes les précautions nécessaires pour éviter les abus.

Pourront encore être permises, avec les mêmes conditions de précaution, la capture, la vente et la détention des oiseaux destinés à être tenus en cage. Les permissions devront être accordées par les autorités compétentes.

\section{Art. 8.}

Les dispositions de la présente Convention ne seront pas applicables aux oiseaux de bassecour, ainsi qu'aux oiseaux-gibier existant dans les chasses réservées et désignés comme tels par la législation du pays.

Partout ailleurs la destruction des oiseaux-gibier ne sera autorisée qu'au moyen des armes à feu et à des époques déterminées par la loi.

Les États Contractantes sont invités à interdire la vente, le transport et le transit des oiseaux-gibier dont la chasse est défendue sur leur territoire, durant la période de cette interdiction.

\section{Art. 9.}

Chacune des Parties Contractantes pourra faire des exceptions aux dispositions de la présente Convention:

$1^{0}$ Pour les oiseaux que la législation du pays permet de tirer ou de tuer comme étant nuisibles à la chasse ou à la pêche ;

$2^{0}$ Pour les oiseaux que la législation du pays aura désignés comme nuisibles à l'agriculture locale.

A défaut d'une liste officielle dressée par la législation du pays, le $2^{0} \mathrm{du}$ présent article sera appliqué aux oiseaux désignés dans la liste $\mathrm{N}^{\prime \prime} 2$ annexée à la présente Convention. 
Art. 10 .

Les Hautes Parties Contractantes prendront les mesures propres à mettre leur législation en accord avec les dispositions de la présente Convention dans un délai de trois ans à partir du jour de la signature de la Convention.

\section{Art. 11.}

Les Hautes Parties Contractantes se communiqueront, par l'intermédiaire du Gouvernement Français, les lois et les décisions administratives qui auraient déjà été rendues ou qui viendraient à l'être dans leurs États, relativement à l'objet de la présente Convention.

\section{Art. 12.}

Lorsque cela sera jugé nécessaire, les Hautes Parties Contractantes se feront représenter à une réunion internationale chargée d'examiner les questions que soulève l'exécution de la Convention et de proposer les modifications dont l'expérience aura démontré l'utilité.

\section{Art. 13.}

Les États qui n'ont pas pris part à la présente Convention sont admis à y adhérer sur leur demande. Cette adhésion sera notifiée par la voie diplomatique au Gouvernement de la République Française et par celu-ci aux autres Gouvernements signataires.

Art. 14.

La présente Convention sera mise en vigueur dans un délai maximum d'un an à dater du jour de l'échange des ratifications.

Elle restera en vigueur indéfiniment entre toutes les Puissances signataires. Dans le cas où l'une d'Elles dénoncerait la Convention, cette dénonciation n'aurait d'effet qu'à son égard et seulement une année après le jour où cette dénonciation aura été notifiée aux autres États Contractantes.

Art. 15.

La présente Convention sera ratifiée, et les ratifications seron échangées à Paris dans le plus bref délai possible.

Art. 16.

La disposition du deuxième alinéa de l'article 8 de la présente Convention pourra, exceptionnellement, ne pas être appliquée dans les 
provinces septentrionales de la Suède, en raison des conditions climatologiques toutes spéciales où elles se trouvent.

En foi de quoi, les Plénipotentiaires respectifs l'ont signée et y ont apposé leurs cachets.

Fait à Paris, le 19 mars 1902.

Pour l'Autriche et pour la Hongrie :

L'Ambassadeur d'Autriche-Hongrie :

(L. S.) Signé : A. Wolkenstein.

(L. S.) Signé : Radolin.

(L. S.) Signé : Baron d'Anethan.

(L. S.) Signé : F. de Leon y Castillo.

(L. S.) Signé : Delcassé.

(L. S.) Signé : N. S. Delyanni.

(L. S.) Signé : Vannerus.

(L. S.) Signé : I. Depelley.

(L. S.) Signé: T. de Souza Roza.

(L. S.) Signé : ÅKerman.

(L. S.) Signé : LaRdy.

Liste No I.

\section{O iseaux utiles.}

Rapaces Nocturnes:

Chevèches (Athene) et Chevêchettes (Glaucidium).

Chouettes (Surnia).

Hulottes ou Chats.Huants (Syrnium).

Effraie commune (Strix flammea L.).

Hiboux brachyotte et Moyen-Duc (Otus).

Scops d'Aldrovande ou Petit-Duc (Scops giu Scop).

\section{Grimpeurs :}

Pics (Picus, Gecinus etc.) toutes les espéces. 


\section{Syndactyles :}

Rollier ordinaire (Coracias garrula L.).

Guêpiers (Merops).

\section{Passereãux-Ordinaires :}

Huppe vulgaire (Upupa epops).

Grimpereaux, Tichodromes et Sitelles (Certhia, Tichodroma, Sitta).

Martinets (Cypselus).

Engoulevents (Caprimulgus).

Rossignols (Luscinia).

Gorges-Bleues (Cyanecula).

Rouges-Queues (Ruticilla).

Rouges-Gorges (Rubecula).

Traquets (Pratincola et Saxicola).

Accenteurs (Accentor).

Fauvettes de toutes sortes, telles que:

Fauvettes ordinaires (Sylvia).

Fauvettes babillardes (Curruca).

Fauvettes ictérines (Hypolais).

Fauvettes aquatiques, Rousserolles, Phragmites, Locustelles (Acrocephalus, Calamodyta Locustella) etc.

Fauvettes cisticoles (Cisticola).

Pouillots (Philloscopus).

Roitelets (Regulus) et Troglodytes (Troglodytes).

Mésanges de toutes sortes (Parus, Panurus, Orites etc).

Gobe-Mouches (Muscicapa).

Hirondelles de toutes sortes (Hirundo, Chelidon, Cotyle).

Lavandières et Bergeronnetes (Motacilla, Budytes).

Pipits (Anthus, Corydala).

Becs-Croisés (Loxia).

Venturons et Serins (Citrinella et Serinus).

Chardonnerets et Tarins (Carduelis et Chrysomitris).

Étourneaux ordinaires et Martins (Sturnus, Pastor etc.).

\section{Échassiers :}

Cigognes blanche et noire (Ciconia). 


\section{Liste No 2.}

\section{O iseaux nuisibles.}

\section{Rapaces Diurnes:}

Gypaète barbu (Gypaetus barbatus L.). Aigles (Aquila, Nisaetus) toutes les espèces.

Pygargues (Haliaetus), toutes les espèces.

Balbuzard fluviatile (Pandion haliaetus).

Milans, Élanions et Nauclers (Milvus, Elanus, Nauclerus), toutes les espèces.

Faucons: Gerfauts, Pélerins, Hobereaux, Émerillons (Falco), toutes les espèces, à l'exception des Faucons kobez, Cresserelle et Cresserine.

Autour ordinaire (Astur, palumbarius L.).

Éperviers (Accipiter).

Cusard (Circus).

Rapaces Nocturnes:

Grand-Duc vulgaire (Bubo maximus Flem.).

\section{Passereaux Ordinaires:}

Grand Corbeau (Corvus corax L.).

Pie voleuse (Pica rustica Scop.).

Geai glandivore (Garrulus glandarius L.).

Échassiers :

Hérons cendré et pourpré (Ardea).

Butors et Bihoreaux (Botaurus et Nycticorax).

Palmipédes :

Pélicans (Pelecanus).

Cormorans (Phalacrocorax ou Graculus).

Harles (Mergus).

Plongeons (Colymbus). 


\section{ALPHABETICAL INDEX}

(NAMES AND SUBJECTS). 



\section{Alphabetical Index (Names and Subjects).}

In this index the names of "useful and noxious birds" grouped by genus and species were omitted for the same reason which induced me not to include in the book a comparative table of birds protected and non-protected. The latter is, namely, in the present state of things, of no practical value and will, indeed only be so, when the signatory States of the Paris Convention of 1902 have published their authentic schedules, a step they have hitherto not taken.

The grouped schedules to be found in the book are as follows:

I. Marenzeller's schedules, 1873 :

a) useful birds . . . . . . . 43

b) noxious birds . . . . . . 44

II. Altum's schedules, 1884 :

a) useful birds . . . . . . . 62

b) noxious birds . . . . . 63

III. French schedules, 1895:

a) useful birds . . . . . . . 104

b) winged game. . . . . . 107

c) noxious birds. . . . . . . 108

IV. The schedule of the International Convention, 1892 :

a) useful birds . . . . . . 134

c) noxious birds. . . . . . 136

V. Hungarian schedule, 1901 :

useful birds . . . . . . . . 156

VI. German Imperial schedule, 1888:

noxious birds. . . . . . . . 164

VII. German Federal States, from 1777 :

useful birds . . . . . . . 165

VIII. English schedule, 1880 :

birds protected . . . . . . 169 
Aachen 165.

Aesthetics 61.

Åkerman 128, 134.

Alsace-Lorraine 80, 165.

Altum 60, 61, 62, 63.

Altum's proposal 62.

Andrássy, Count Gyula, 4, 52, 54, $88,95$.

d'Anethan, Baron, 127, 134.

Apostolic King 1, 126.

Apponyi, Count Albert, 4, 175.

d'Arco, Count, 100.

Arrigoni 199.

Association of French "Chasseurs"

114 seq.

Au lacet 37.

Au largon 37.

Austria 58, 100.

Austria, Emperor of, 126, 127.

Austria, state of things in, 78 .

Au trèbuchet 37 .

Bachner 65, 78.

Baden 80, 165.

Baldamus 33, 59, 60, 66, 149.

Baldamus, statement of, 33 .

Balkans, state of things in, 78 .

Báthory, Ferdinand, 73.

Bats 155 .

Bavaria 80, 100, 165, 167.

Beak 11 seq.

Beck, Max, 97, 100.

Belgians, King of the, 126, 127.

Belgium 57, 81, 101.

Berg, Baron, 77.

Berlepsch, Baron John, 76, 90, 154, 174-5.

Berlepsch-principle 174.

Berlepsch's Report 90 seq.

Berlin Resolution, 1895, 99.

Berzeviczy, Albert, 71.

Bethlen, Count Andrew, 57, 76, 86.

Bikkesy 77.

Bill, of Birds, 11.

Bird-catching colony 92.

Bird-protection in Hungary 145 seq.

Bird-protectors, English, 173.
Birds 10 seq.

Birds and Man 20.

Birds and Nature 9.

Birds, Destruction of, in the South 90 .

Birds, Dictionary of, 199 seq.

Birds, feet of, 12.

Birds, food of, 13, 17.

Birds of passage 67 et passim.

Birds of prey, foot of, 12.

Birds, Transport of, 129, 130.

Birds, Wing of, 10.

Bishop 76.

Blanchard 101.

Blasius, R., 60, 69, 72, 76.

Blasius, W., 60, 76.

Blomeyer 38, 49.

Blomeyer's proposal 47.

Bohemia 79.

Boitel 38.

Bonde, Baron, 102.

Borggreve 60 .

Borggreve's proposal 64, 67.

Bossi-Fedrigotto 47.

Brehm, Alfred, 38, 43, 49, 163, 174, 199.

Brehm, A.'s, Report 45-47.

Bremen 165, 167.

Brescia, market of, 21.

Brocchi 101.

Bromberg 165.

Broods 36, 41, 89, 113, 173.

Büchner 76.

Bukovina 79 .

Bultman 102.

Bustard 115, 163.

Bustard, Houbara, 115.

Bustard, Little, 116, 163.

Büttikofer 76.

Carinthia 79.

Cassel, colony at, 175.

Castillo, de, 127, 134.

Chadbourne 76.

"Chasseurs", French, 114.

Chernel, Stephen, 150, 152.

Chiff Chaff, bill of, 11 .

Chlumetzky, Baron, 38. 
Chouette 36.

Circular Decree 155 seq., 172.

Claus, Professor, 76.

Collett, Professor, 76.

Comparisons 163 seq.

Conference, International, 1895, 100.

Congress, Economic, 38.

Congress, Ornithological, v. Ornithological Congress.

Contracts 34 .

Convention, Discussion of, 100 seq.

Convention, Draft of, 103, 113.

Convention, Preliminaries of, 93.

Conventions $35,51$.

Convention, Text of, 126 seq.

Cordeaux, John, 76.

Corpus juris 1, 125.

Crao, stonefield, 21.

Criesis 102.

Csáky, Count Albin, 71, 73, 76, 146.

Csató, John, 74.

Csörgey, Titus, 153, 175.

Czettel, Gyula, 152.

Dalmatia 79.

Dante 140.

Darányi, Ignácz, 4, 121, 125, 151, 175 seq.

„Declaration“, 1875, 52, 59, 68, 83, 84, 138.

Declaration", Text of, 52-54.

Delcassé 127, 134.

Delegates, 1895, 100-102.

Delyanni 127, 134.

Depelley 128, 134.

Developments 56 .

Dictionary of Birds 199 seq.

Documents 221 seq.

Draining off 15, 29.

Dresser 5, 199.

Dunay's motion 65.

Dundas-Harford 102.

English Act 82, 168.

English bird-protectors 173.

English „isolation“ 57, 167.

English, schedule, 169 seq.

Entz, Dr. Géza, 73.
Eszterházy, Count Paul, 101.

Fatio 60, 66, 76, 102.

Fatio's proposal 64 .

Fatio's text 66.

Faucon cresserelle 138.

Faucon cresserine 138.

Faucon kobez 138.

Feet of birds 12.

Fereira 102.

Festetics, Count Andor, 96.

Finsch, Dr., 76.

Flamingo 106, 163.

Flycatcher, Pied, 21.

Fly-catcher, Spotted, 21.

Food of people 31 .

Force majeure 19.

Forests, extirpation of, 29, 45.

Forgách, Count, 21.

France 94 seq., 101.

France, state of things in, 78 .

Frauenfeld 35, 52.

Frederick, the Emperor, 32.

French Draft 103, 163.

French invitation 94, 95.

French proposal 103

French Republic, President of, 126.

Frivaldszky, John, 70, 73, 74.

Fulton 27.

Fürbringer, Dr., 75, 76.

Future, The, 174.

Gadaut 103.

Gaetke, Henry, 18.

Galicia 79.

Game Laws, Hungarian, 88, 124, 147.

Gérard 101.

German antagonism 57-58.

German Emperor 126.

German Farmers and Foresters 32, 33.

German Federal States 80 seq., 164.

German Imperial Law 79, 164.

German "noxious" birds 164.

German Ornithological Society 33.

German „protected" birds 165-66. 
Germany $31,32,58,79,96,100$, 164 seq.

Ghiorghieff 76 .

Ghyczy, Fieldmarshal Béla de, 77. Giglioli, Professor, 60, 66, 68, 75, 97, 102.

Giglioli's Statement 66, 110.

Gilbert 101.

Gins 113.

Girtanner 60 .

Gloger 163.

Gloger's principle 43.

Görz 79.

Gradiska 79 .

Grands filets 37 .

Grasshopper danger 115 .

Great Britain 60, 82, 102, 117.

Greece 102.

Grobben, Professor, 76.

Györy, Loránd, 5.

d'Hamonville 76 .

Hartert 76.

Háry, Gyula, 151.

Hawfinch, beak of, 12.

Hayek, Dr., 70, 71.

Hedgehogs 155 .

Hellenes, King of the, 127.

Hennequin 101.

Herman, Otto, 70, 73, 74, 76, 94, $152,153$.

Hesse 33, 80 .

Holland 68, 81, 102, 117.

Homeyer, A., 76, 77.

Homeyer, E., 60, 62, 63, 66.

Horatius 140.

Horváth, Dr. Géza, 70, 73, 76.

Hungarian Act I (1906) 126 seq.

Hungarian Central Office for Ornithology $120,135,147,148$ seq.

Hungary $58,88-89,100,145$ seq.

Increase 18-19.

Induction 27.

Instructions 66 .

Internationalism 31, 32.

„Isolation", English 57, 167.

Italian bird-markets 23 .
Italy $34,58,102,117,138$.

Italy, state of things in, 78, 91 .

Japanese "close time“, 188466.

Kállay, Benjamin, 76.

Kargl's proposal 49.

Kermenič's proposal 65 .

Kestrels 62, 104, 138.

Keulemans 151.

King, Apostolic, v. Apostolic King.

Kingfisher, feet of, 12 .

Köhler 153.

König, Professor, 97, 100.

König-Warthausen 76, 77.

Koppély, G., 77.

Krain 79.

Kriesch, John, 70.

Kulagin 102.

Labourer-bands 14 .

Lanciaxera 53, 99.

Lardy 128, 134.

Larks' wings 22, 122.

Lehmann 97.

Licences 36, 41, 130, 161, 162.

Lichtenstein, Prince, 126.

Liebe, Dr., 75.

Liebig 28.

Lippe-Detmold 32, 96, 165, 167.

Little Owl 36, 81.

Löcherer, A., 77.

Locusts, plague of, 116 .

Lorenz 76.

Luxemburg 102.

Luxemburg, Grand Duke of, 127.

Luxemburg's proposal 112.

Madarász, Dr. Gyula, 70, 73.

Máday, Izidor, 74, 75, 83.

Máday's proposal 84 .

Máday's Report 83 seq.

Maltzan 38.

Mammals 155.

Marchand 101.

Marenzeller 38, 49.

Marenzeller's proposal 42-43.

Marenzeller's schedule 43-45.

Maxwell 102.

Mayer 102. 
Mecklenburg 165.

Méline 101, 103, 121.

Michel 77.

Middendorff 38, 49, 76.

Middendorff's proposal 49 .

Modifications 113, 129, 130, 133

Moles 155.

Monaco, Prince of, 127.

Montegrado, valley of, 21.

Moragas 101.

Moravia 79.

Müller, Ladislaus, 4.

Natural conditions 15.

Naturalien-Cabinet 35 .

Naumann 33, 199.

Nécsey, Stephen, 151-2.

Nesting-boxes 4, 89, 173, 175.

Nets 53, 129.

Newton, Professor, 74, 76.

Nooses 36, 41, 43, 53, 129.

Norway 82, 102.

Nourishment, researches into mode of, 17 and note.

Novallas, Marquis, 101.

Noxious birds 44, 100.

Noxious birds, 1895, 108.

Noxious birds, 1902, 136-7.

Nuthatch, foot of, 12.

Oldenburg 165.

Orazio 139.

Oriole, Golden, 138.

„Ornis" 70.

Ornithological Congress I. 1884 59 seq.

Ornithological Congress II. 1891 75 seq.

Ornithological Congress III. 1900 $121,123$.

Ostrich 10.

Otis houbara 115.

Otis tetrax 116.

Oustalet 60, 75, 76, 101.

Owl, Little, v. Little Owl.

Palacky 60, 76.

Palacky's proposal 64.

Pallisch 77.
Palmén 75, 76.

Paretajo 37.

Parexella 53.

Parey 150.

Paris, Conference at, 1895, 100.

Partridges, wings of, 11.

Passata 92.

Paszlavszky, Joseph, 70.

Persons, Names of, 187 seq:

Petényi 33.

PIOC. 68, 69, 70, 86.

Pipit, Tree, 136, 157

Plocke 53, 99.

Plover, ringtoed, foot of 12.

Poirson 101.

Polten 68.

Portugal, King of, 127.

Poyard 103.

Preliminary Conference, 1895,96, 97.

Pressanella 91.

Prost 101, 112.

Protocol, 1875, 55.

Prussia, King of, 126.

Prussia; state of things in, 80 .

Pulszky, Francis, 76.

Quail-catching in the South 93, 116.

Quails, importation of, 21, 116.

Quails, wings of, 11.

Radde 60.

Radolin, Prince, 127, 134.

Raoul 76.

Ratification 125.

Rava, Minister, 139.

Reichenow 76.

Reichenow, Dr., 74.

Restrictions 19.

Reuss-Gera 165.

Reuss-Greiz 165.

Ritzema-Bos 102.

Robert 114.

Roccolo 36, 41, 91, 140

Roganja 36.

Rösler, John K., 153.

Róth, Loránd, 5.

Royal Society 173.

Rudolf, Crown Prince, 60, 69, 71. 
Russ $60,76,77,85$.

Russia 117.

Russia, state of things in, $65-66$, 78.

Russ's motion 64, 85.

Russ's resolution 66,85 .

Saárossy-Kapeller 96, 101.

Sachs-Altenburg 165.

Sachs-Coburg 32-33, 165.

Sachs-Meiningen 165.

Sachs-Weimar 165.

Sagnièr 101, 102.

Salvadori 21.

Salzburg 79.

Saunders 102.

Saxony 80, 165.

Schäff 76.

Schalow 76.

Schedule, English, 169-172.

Schedule, of winged game, 1895 107, 112.

Schedules, 1902134 seq.

Schedules, French, 104-110.

Schedule, German, 165-167.

Schedule, Hungarian, 155-160.

Schrenck 60.

"Schwalbe" 33 (note), 60.

Schwarzburg 165.

Sclater, Ph. L., 75, 76.

Seebach, colony at, 175 .

Seidl 77.

Selenka, Professor, 97, 100.

Settegast 38, 49.

Settegast's proposal 48 .

Sharpe, R. B., 74, 75.

Shrew 155.

Silesia 79.

Snare 50, 53, 113.

Souza, de, 128, 134.

Spain 60, 101, 125.

Spain, King of, 126.

Spain, state of things in, 78 .

Spoonbill, beak of, 11 .

Springrod 36.

Starling 14, 17, 49.

Statute Book 1.
Stauronotus Grasshopper 116.

Stephenson 27.

Straten-Ponthoz, proposal of, 47.

Styria 79.

Survey, Historical, 179 seq.

Sverdrup 102.

Swallows, millions of, 21 .

Swallow, wing of, 11 .

Sweden 82, 102, 133.

Sweden, King of, 127.

Swedish modifications 120 seq.

Swift, feet of, 12.

Swiss Federal Council 34, 35, 127.

Swiss modifications 119 seq.

Switzerland 81, 90, 102.

Symbiosis 14.

Szalay, Imre, 73.

Szalkay, Dr., 77.

Szeniczey, Edmund, 77.

Szily, Kálmán, 73.

Szögyény, Ladislas, 57, 71.

Szomjas, Lajos, 5.

Taeschlein 77.

Taking of birds permitted 53 .

Tallián, Béla, 125.

Tallián, Dénes, 4.

Talszky 77.

Talszky's principle 64 .

Tamásy 77.

Targioni-Tozetti 35, 52.

Täschlein, v. Taeschlein.

Tessin, Canton of, 34 .

Thesis 16.

Thiel 97, 100, 111.

Thorburn 151.

Tischer 77, 86.

Tischer's proposal 86 .

Tisserand 101, 112.

Titmice 174.

Titmouse, Blue, 135, 158.

Titmouse, Great, 135, 157.

Titmouse, Longtailed, beak of 11 .

Torelli 48.

Torelli's proposal 48 .

Transference, 1887, 69.

"Transito" transport 115 . 
Traps 36, 41, 43, 50, 53, 81, 129 . Watt, James, 27.

Triest 78.

Wattenwyl, Emil de, 4.

Tschudi, Dr., 38, 49.

Wekerle, Alexander, 125.

Tschudi's proposal 39, 40-41.

Wešniakoff 38.

Tschusi, Ritter von, 5, 76, 100, 119.

Whitethroat 158.

Turkey, state of things in, 78 .

Whitethroat, Lesser, 158.

Typaldo 102.

Tyrol 79.

Udine, Market of, 21.

Useful birds 43 .

Useful birds, 1895, 104.

Useful birds, 1902, 134 seq.

Vadászfy 77.

Vallon, Professor, 21, 78.

Vannerus 102, 128, 134.

Wild Birds Protection Act 82, 168.

Wing, The, 10.

Wolffersdorf 77.

Wolkenstein, Count, 127, 134.

Woodcock, Bill of, 12.

Woodpecker, Foot of, 12.

Wren 105, 158.

Wren, Golden-crested, 18.

Württemberg 80, 165,

Vienna Resolution, 1873, 50-51. Xanthus, John, 74.

Visconti-Venosta 52, 54 .

Waldeck 165.

Zeller 77.

Zeppelin 76, 77.

Zichy, Count, 38.

Wandering birds 67 .

Wangelin 75, 77.

Zimmermann 77.

Wangelin's Report 33 (note), 77 seq. Zselénszky, Count, 140. 



\section{DIGEST OF THE}

\section{LIBRARY REGULATIONS.}

No book shall be taken from the Library without the record of the Librarian.

No person shall be allowed to retain more than five volumes at any one time, unless by special vote of the Council.

Books may be kept out one calendar month; no louger without renewal, and renewal may not be granted more than twice.

A fine of five cents per day incurred for every volume not returned within the time specified by the rules.

The Librarian may demand the return of a book after the expiration of ten days from the date of borrowing.

Certain books, so designated, cannot be taken from the Library without special permission.

All books must be returned at least two weeks previous to the Annual Meeting.

Persons are responsible for all injury or loss of books charged to their name. 




\section{DATE DUE}

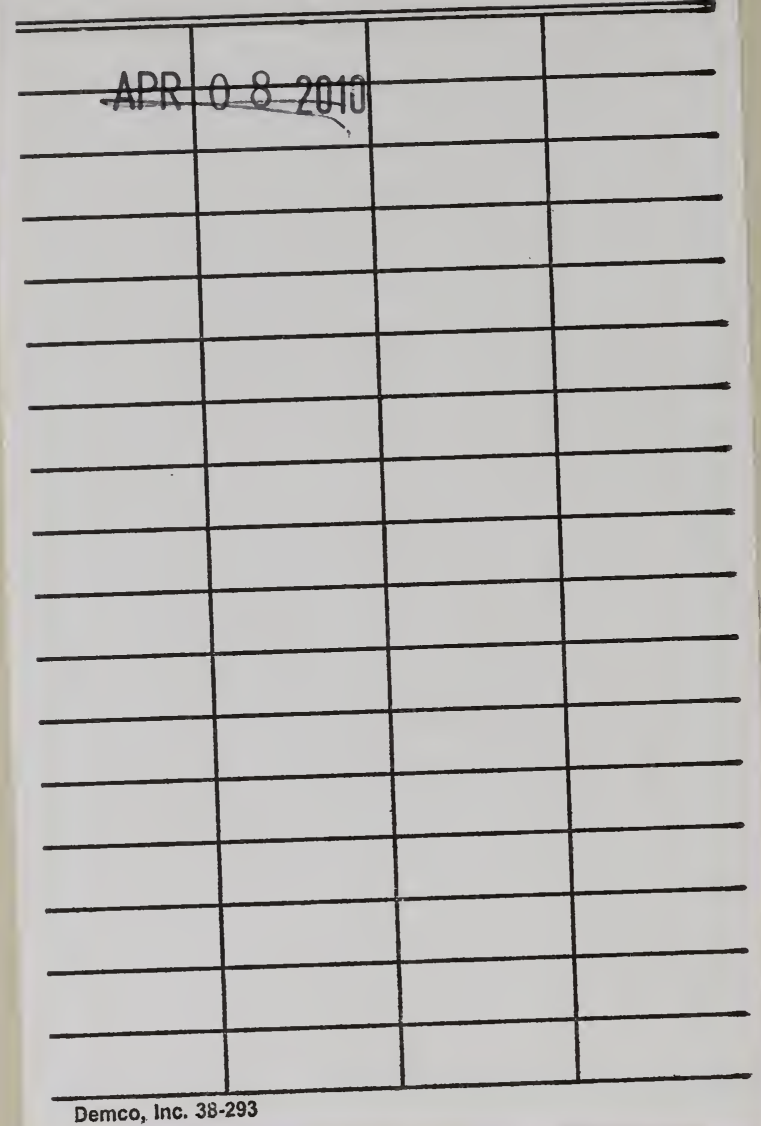


